ORNL --6640

DE9 I 005629

ORNL-664()

\title{
GREENHOUSE GAS EMISSIONS IN SUB-SAHARAN AFRICA
}

\author{
Robin L. Graham \\ Robert D. Perlack \\ Anantha M. G. Prasad \\ Jack W. Ranney \\ Daniel B. Waddle \\ DATE PUBLISHED - Novenber 1990 \\ Prepared for the \\ Office of Technical Resources \\ Bureau for Africa \\ Agency for International Development \\ Prepared by the \\ GAK RIDGE NATIONAL LABORATORY \\ Oak Ridge, Tennessee 37831-6285 \\ operated by \\ MARTIN MARIETTA ENERGY SYSTEMS, INC. \\ for the \\ U.S. DEPARTMENT OF ENERGY \\ under contract DE-AC05-84OR21400
}




\section{CONTENTS}

LIST OF FIGURES $\ldots \ldots \ldots \ldots \ldots \ldots \ldots \ldots \ldots \ldots \ldots \ldots \ldots \ldots \ldots$

LIST OF TABLES $\ldots \ldots \ldots \ldots \ldots \ldots \ldots \ldots \ldots \ldots \ldots \ldots \ldots \ldots \ldots \ldots \ldots$

ACKNOWLEDGMENTS $\ldots \ldots \ldots \ldots \ldots \ldots \ldots \ldots \ldots \ldots \ldots \ldots \ldots \ldots \ldots \ldots \ldots$

SUMMARY $\ldots \ldots \ldots \ldots \ldots \ldots \ldots \ldots \ldots \ldots \ldots \ldots \ldots \ldots \ldots \ldots \ldots \ldots \ldots$

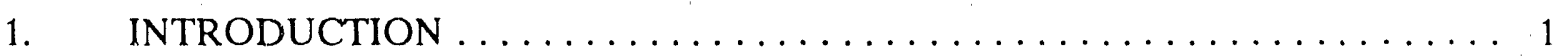

1.1 DESCRIPTION OF THE STUDY AREA $\ldots \ldots \ldots \ldots \ldots \ldots \ldots \ldots$

1.2 JUSTIFICATION FOR CARBON DIOXIDE EMPHASIS $\ldots \ldots \ldots \ldots \ldots 1$

1.3 GENERAL APPROACH $\ldots \ldots \ldots \ldots \ldots \ldots \ldots \ldots \ldots \ldots$

1.4 STUDY TEAM ORGANIZATION $\ldots \ldots \ldots \ldots \ldots \ldots \ldots \ldots \ldots \ldots \ldots$

1.5 REPORT ORGANIZATION ................... 4

2. GREENHOUSE GASES AND VEGETATION IN SUB-SAHARAN AFRICA . . 5

2.1 THE GREENHOUSE CONCEPT $\ldots \ldots \ldots \ldots \ldots \ldots \ldots \ldots \ldots$

2.2 GREENHOUSE GASES FROM SUB-SAHARAN AFRICA $\ldots \ldots \ldots$.

2.3 CARBON CYCLING AND TERRESTRIAL VEGETATION $\ldots \ldots \ldots$

2.3.1 Plant-Level Carbon Dynamics $\ldots \ldots \ldots \ldots \ldots \ldots \ldots \ldots$

2.3.2 Ecosystem-Level Carbon Dynamics . . . . . . . . . . . . . 11

2.3.3 Landscape and Regional Carbon

Dynamics ........................ 12

2.3.4 Vegetation and the Global Carbon Cycle $\ldots \ldots \ldots \ldots \ldots \ldots$

2.4 FORESTS AND LAND USE IN SUB SAHARAN AFRICA . . . . . . . 13

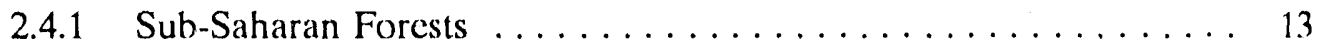

2.4.2 Land Use: Options in Sub-Saharan

Africa ............................ 14

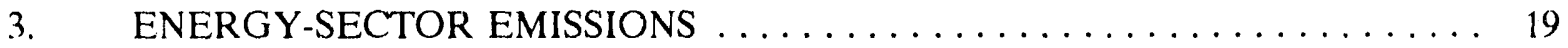

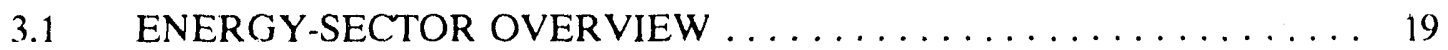

3.2 CARBON EMISSIONS FROM ENERGY CONVERSION . . . . . . . 20

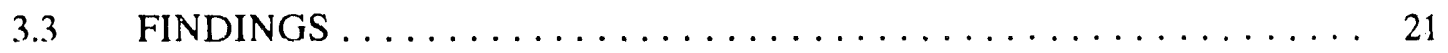

3.4 EMISSION-REDUCTION OPPORTUNITIES $\ldots \ldots \ldots \ldots \ldots \ldots \ldots$

4. BIOLOGICAL SARBON ESTIMATES AND IMPACTS $\ldots \ldots \ldots \ldots \ldots \ldots \ldots$

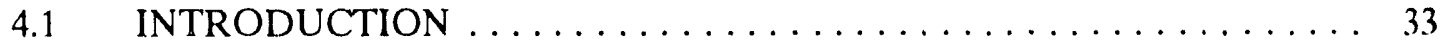

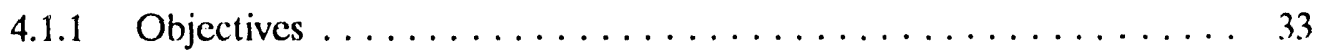

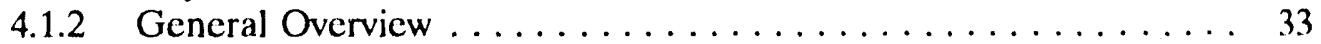

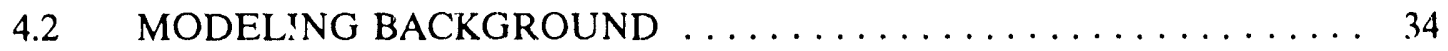

4.2.1 Base-Case Modeling Approach $\ldots \ldots \ldots \ldots \ldots \ldots \ldots \ldots \ldots \ldots$

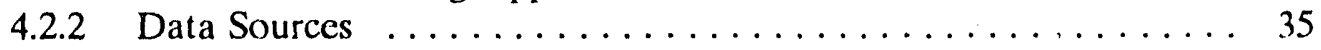

4.2.3 Modeling with Geographical

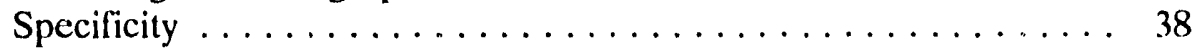


CONTENTS (continued)

$\underline{\text { Page }}$

4.3 COMPONENTS OF THE CARBON INVENTORY AND

EMISSION MODEL $\ldots \ldots \ldots \ldots \ldots \ldots \ldots \ldots \ldots \ldots \ldots \ldots$

4.3.1 Modeling Land-Use Dynamics . . . . . . . . . . . . . . 41

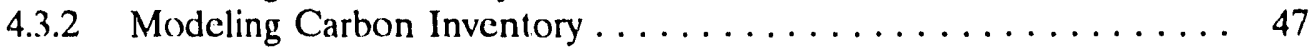

4.3.3 Modeling Annual Carbon Emissions ............... 54

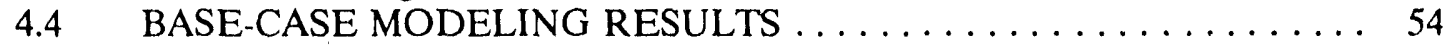

4.5 COMPARISON OF METHODOLOGY AND RESULTS WITH

OTHER APPROACHES $\ldots \ldots \ldots \ldots \ldots \ldots \ldots \ldots \ldots$

4.6 EVALUATION OF LAND-USE MANAGEMENT OPTIONS . . . . . . 64

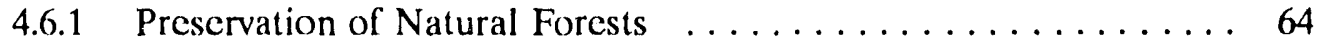

4.6.2 Agroforestry and Fuelwood $\ldots \ldots \ldots \ldots \ldots \ldots \ldots \ldots \ldots \ldots$

4.6.3 Industrial Reforestation . . . . . . . . . . . . . . .

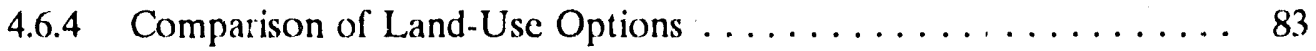

4.7 REMOTE SENSING RESULTS .................. 86

4.7.1 Comparison of AVHRR Interpretation of Forest and Savanna (Open Land) of Central Africa and

FAO Vegetation Map .................. 86

4.7.2 Landsat Analysis of Land-Cover Change

in Central Africa . . . . . . . . . . . . . . . . . . . . 89

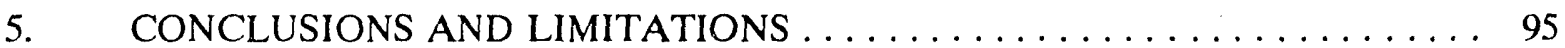

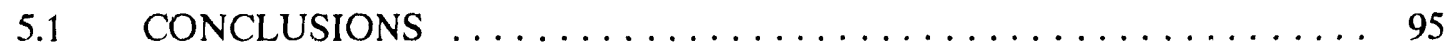

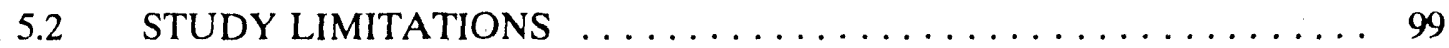

5.2.1 Data Deficiencies ........................ 99

5.2 .2 GIS Analysis Deficiencies . . . . . . . . . . . . 100

APPENDIX 1. CONVERSION FACTORS AND ENERGY VALUES USED

IN ENERGY ANALYSIS $\ldots \ldots \ldots \ldots \ldots \ldots \ldots \ldots \ldots \ldots$

APPENDIX 2. ENERGY CONSUMPTION BY COUNTRY $\ldots \ldots \ldots \ldots \ldots 107$

APPENDIX 3. COMPARISON OF FAO AND AVHRR VEGETATION

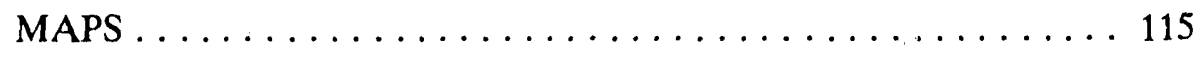

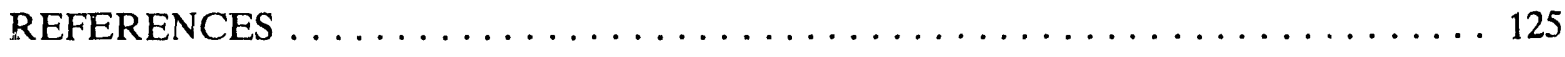




\section{LIST OF FIGURES}

\section{Figure}

$\underline{\text { Pagc }}$

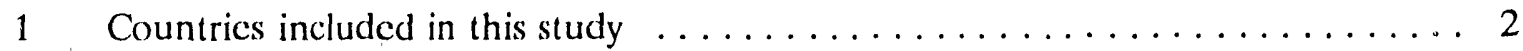

2 Global greenhouse gas emissions, their relative heating contributions and their geographic distribution $\ldots \ldots \ldots \ldots \ldots \ldots$

3 Annual energy consumption in Sub-Saharan Africa assuming

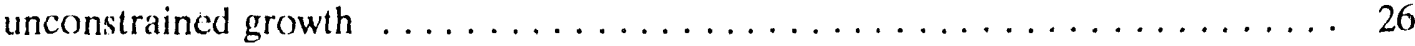

4 Annual energy consumption in Sub-Sarahan Africa assuming implementation of energy conservation program $\ldots \ldots \ldots \ldots \ldots \ldots \ldots 27$

5 Energy sector carbon emissions in Sub-Saharan Africa

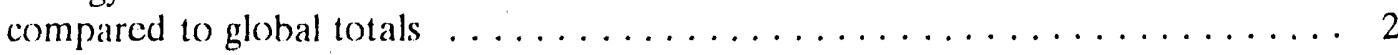

$6 \quad$ Illustration of point sampling sirategy used in characterizing geographic variability in carbon emissions and inventory in Sub-Saharan Africa . . . . . . . . . . . . . 39

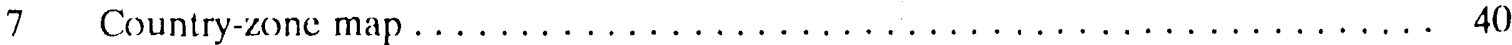

8 Overlaying digital maps in a geographic information system to extract variables and create a data base $\ldots \ldots \ldots \ldots \ldots \ldots \ldots . \ldots 2$

9 Major steps involved in the methodology for predicting carbon

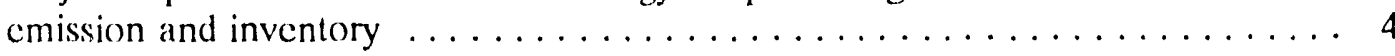

10 Flow chart of SAS program for predicting carbon

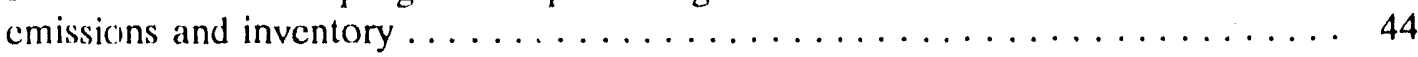

11 Model of land-use dynamics used to predict carbon

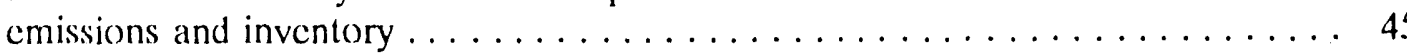

12 An example illustrating model calculations of carbon emission and inventory at a point, at time $\mathrm{t}$ and $\mathrm{t}+1$

13 Emissions from the top three carbon-emitting countries

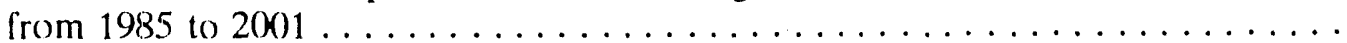

14 Carbon emissions from Sub-Saharan Africa with and without forest preservation . 66

15 Comparison of average annual emissions from Sub-Sarahan

Africa between 1991 and 2001 under different forest

preservation scenarios 
LIST OF FIGURES (continued)

16

(a) Location of pairs of Landsat imagery and (b) subsites with Landsat scenes of Central African Republic ................... 91

vi 


\section{LIST OF TABLES}

Table

$\underline{\text { Page }}$

1 Characteristics of the major greenhouse gases $\ldots \ldots \ldots \ldots \ldots \ldots \ldots \ldots$

2 Annual global emissions budget estimates for four radiatively important gases . ........................... 7

3 Energy use in thousands of tonnes oil equivalent $\ldots \ldots \ldots \ldots \ldots \ldots \ldots \ldots$

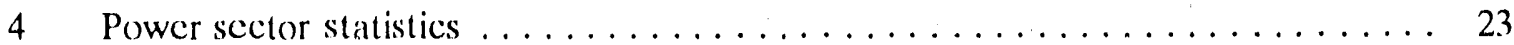

5 Carbon emissions by year (in millions of tonnes of carbon) $\ldots \ldots \ldots \ldots \ldots \ldots$

6 Data bases used in modeling carbon inventory and emissions in

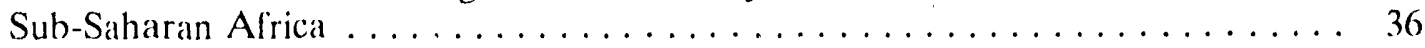

7 Dominant vegetation types in the Sub-Saharan portion of the

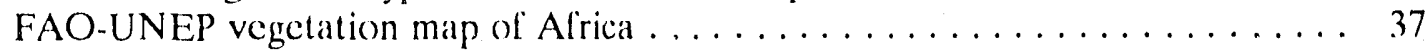

8 Assumed crop and fallow years for each country and zone $\ldots \ldots \ldots \ldots \ldots \ldots$

9 Rules used to assign carbon values to land-use classes at each point on the basis of initial (1985) point land use $\ldots \ldots \ldots \ldots \ldots \ldots \ldots . \ldots . \ldots$

10 Example of point calculation of carbon inventory for a

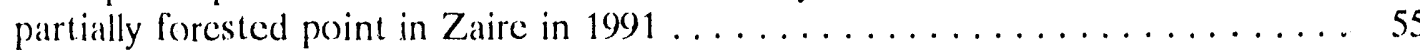

11 Base case model predictions of carbon emission and inventory (millions of tonnes) in Sub-Saharan Africa in 1985, 1993, and $2001 \ldots \ldots \ldots$. 56

12 Base case model predictions of carbon emissions from 1991 to 2001 in the 10 largest carbon-emitting countries of Sub-Saharan Africa . . . . . . . . .

13 Comparison and ranking of carbon emissions (tonnes $\mathrm{C} / \mathrm{ha}$ ) among the countries of Sub-Saharan Africa in terms of carbon released per hectare in 1985,1993 , and 2001

14 Comparison and ranking of carbon emissions predicted by A.I.D. model and Houghton models. 


\section{LIST OF TABLES (continued)}

Table

Page

15 Additional land (millions of hectares) in forests in 2001 under different deforestation reduction seenarios with recovery of degraded vegetation . . . . . . . . . . . . . . . . . . 69

16 Countries and zones in which agroforestry was implemented $\ldots \ldots \ldots \ldots \ldots 73$

17 Land under agroforestry in 2001 in countries and zones of

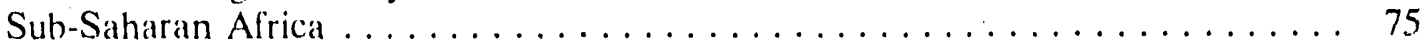

18 Carbon inventory and emissions (millions of tonnes) under different agioforestry secnarios compared to the base case $\ldots \ldots \ldots \ldots 77$

19 Area of nonforest land in the three plantation suitability classes by country and zone $\ldots \ldots \ldots \ldots \ldots \ldots \ldots \ldots \ldots \ldots$

20 Amount of carbon (in millions of tonnes) that would be stored annually under each of the four plantation scenarios . . . . . . . . . . 84

21 Amount of land (in thousands o. hectares) that would be planted each year under each plantation scenario $\ldots \ldots \ldots \ldots \ldots \ldots \ldots \ldots$

22 Grouping of FAO vegetation classes occurring in central Africa into three land cover classes $\ldots \ldots \ldots \ldots \ldots \ldots \ldots \ldots \ldots \ldots \ldots$

23 Correspondence matrix of AVHRR class values and FAO class values $\ldots \ldots \ldots 88$

24 Date and location of Landsat MSS and SPOT imagery used in

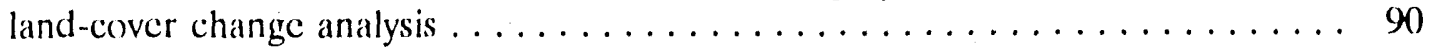

25 Vegetation cover and forest change statistics of six Central African Republic subsites . . . . . . . . . . . . . . . . . . . . . . 94 


\section{ACKNOWLEDGMENTS}

Information and assistance is gratefully acknowledged from the individuals and institutions listed below.

K.D. Singh

Dora DeCoursey

Andrew Millington

Richard Saull

Michel Leveriere

Bob Winterbottom

Tom Holme

Don Moore

Tom Loveland

Jeff Goodson

Tom McShane

Richard Carol

Barry Henrickson

Harvey Croze

Ron Witt

Tom Comcau

Louis Iverson

William Sprinsky

Sandra Brown

Chris Rovero

Steven Borgelt

William F. Barron

Cathy Gaudreau

Polly Henry
FAO, Rome, Italy

FAO, Rome, Italy

U. of Reading, U.K.

U. of Rcading, U.K.

CIDA, Quebec, Canada

World Resources Institute, Washington, D.C.

USGS, EROS Data Center

USGS, EROS Data Center

USGS, EROS Data Center

A.I.D., Abidjan, Ivory Coast

World Wildlife Fund, Washington, D.C.

World Wildlife Fund, Washington, D.C.

IEGAD, Nairobi, Kenya

GRID, Nairobi, Kenya

GRID, Geneva, Switzerland

TYDAC, Co. (formerly Environment Canada)

Illinois Natural History Survey

Texas A\&M University

U. of Illinois

Oak Ridge Associated Universitics

U. of Missouri

U. of Hong Kong

Oak Ridge National Laboratory

Oak Ridge National Laboratory 


\section{SUMMARY}

Current and future carbon emissions from land-use change and energy consumption were analyzed for Sub-Saharan Africa. The energy sector analysis was based on UN energy data tapes while the land-use analysis was based on a spatially-explicit land-use model developed specifically for this project. The impacts of different energy and land-use strategies on future carbon emissions were considered. (A review of anthropogenic emissions of methane, nitrous oxides, and chlorofluorocarbons in Sub-Saharan Africa indicated that they were probably minor in both a global and a regional context. The study therefore was locused on emissions of carbon dioxide.)

The land-use model predicts carbon emissions from land use change and the amount of earbon stored in vegetation (carbon inventory) on a yearly basis between 1985 and $2(0) 1$. Emissions and inventory are modeled at 9000 regularly-spaced point locations in Sub-Saharan Africa using location-specific information on vegetation type, soils, climate, and deforestation. Vegetation, soils, and climate information were derived from continental-scale maps while relative deforestation rates (\% of forest land lost each year) were developed from countryspecific forest and deforestation statistics (FAO Tropical Forest Resources Assessment for Africa, 1980). Point estimates were aggregated to make country estimates and in some cases subcountry estimates. All emissions of carbon sequestering per unit hectare were assumed to accrue the year of land-use conversion. The temporal dynamics of plantation growth or decomposition were not modeled. This simplification facilitated comparison between different land-use strategies. The carbon emissions under different land use strategies in Sub-Saharan Africa were analyzed by modifying deforestation rates and altering the amount of carbon stored under different land uses. The considered strategies were: preservation of existing forests, implementation of agroforestry, and establishment of industrial tree plantations. These three managrment options were chosen to addre's the root causes of deforestation in Sub-Saharan Africi - agricultural encroachment, fuelwood demand, and logging. The validity of the model was ealuated by comparing the model cmission predictions, assuming current land use trends, wit. current emission values predicted by other studies. The model predictions were within the bounded estimates of the other studies.

Using current land-use trends, the land-use model results show that three countries (Ivory Coast, Zaire, and Nigeria) alone contributed over 5)\% of 1985 carbon emissions from land use change in Sub-Saharan Africa. The Ivory Coast and Nigeria emissions are predicted to decline rapidly over time as their rapid rates of deforestation (7\% and $3 \%$ loss per year) deplete their forest base. Emissions from Zaire do not dedine rapidly because of its vast forest areas and its current low rate of deforestation (only $0.2 \%$ loss per year). Angola, the Central African Republic, Congo, and Gabon are also similar to Zaire, having low emission rates (respectively, $0.18 \%, 0.15 \%, 0.1 \%$ and $0.07 \%$ loss per year) with sizable forest areas. For all of the Sub-Saharan countries examined, total carbon emissions from deforestation are estimated at approximately 200 million tonnes in 1985 . This total is projected to decline to about 140 million tonnes in 2001 assuming no change in deforestation rates - a result of continued deforestation and reduction in forest area. Over the 1985 to 2001 study period, carbon emissions are projected to average approximately 165 million tonnes per year. These land-based emissions represent only a small fraction of current total global emissions of carbon but a significant fraction (about $20 \%$ ) of carbon emissions from global tropical deforestation. 
If deforestation accelerated in Zaire and the other countries of the Congo basin, landbased emissions from Sub-Saharan Africa could become much more significant in a global context. For example, a tripling of Zaire's deforestation rate to $0.6 \%$ year, still far below that of the Ivory Coast or Nigeria, would cause carbon emissions from Sub-Saharan Africa to increase by $30 \%$. If Zaire's deforestation rate was the same as the Ivory Coast, emissions would be 500 million tonnes of carbon per year or about a tenth the current global fossif fuel emissions. The current deforestation statistics for Zaire are old (pre-1980) and based on incomplete information. If timber extraction increases significantly, as it may due to reduced logging in Brazil and Asia, then emissions from Zaire could increase substantially. Quality information and statistics on land-use and land-use trends are badly needed to ascertain the real risk in this region. Current emissions from land-use change must also be considered in their historic context. Considerable loss of forest land has already oecurred in Sub-Saharan Africa. The closed forests that banded western Africa are now largely gone. The only remaining extensive tracts of intact forest are in central Africa.

Of the three land use options for reducing carbon emissions, aggressive forest protection (total halt of deforestation in conjunction with recovery of degraded forest) yielded the greatest carbon benefit. Under this option, average annual carbon emissions between 1991 and 2001 change from 152 million tonnes to a net sequestering of 62 million tonnes each year as degraded forests put on new growth and sequester new carbon. Halving current deforestation rates but allowing the existing forest to recover would reduce net emissions to 21 million tonnes per year. The estimate of carbon sequestering potential with forest preservation is conservative as the estimates of both the extent of degraded forest and the degree of degradation are conservative. More carbon, perhaps as much as 2 or 3 times more, could be sequestered during the recovery of degraded forests. Unfortunately, the potential to store carbon in new tree growth quickly diminishes as the forests reach fill recovery and would disappear within a few decades. It should also be noted that the preservation scenario is not a restoration secnario. That is, existing forest is preserved but former forest-land is not restored to forest.

Widespread adoption of agroforestry also yiclded significant reductions in carbon emissions. Assuming a high level of adoption (4\% of the agricultural land was converted to agroforestry each year) and assurning the agroforestry site contained $40 \%$ of the tree biomass that would be encountered in an industrial plantation, the model predicted that Sub-Saharan carbon emissions would drop from an average of 152 to 20.2 million tonnes per year. A more realistic, but still optimistic, adoption rate of $2 \%$ per year and a lower tree biomass assumption (20\% of the biomass of an industrial plantation) reduced emissions to 114 million tonnes per year.

Establishment of industrial plantation forests, assuming implementation rates comparable to those recommended by the Tropical Forestry Action Plan, are predicted to reduec regional carbon emissions by 5 million tonnes per year. Assuming that $0.1 \%$ of all land biologically capable of supporting industrial plantations (this includes the agriciltural land base but excludes current forcst land) was converted to plantation annually, the annual carbon savings were predicted to be about 10 million tonnes per year. Offsetting all industrial roundwood removals with plantations would save about 18 million tonnes of carbon annually. 
The minimum costs for implementing these options were estimated to range between $\$ 25$ and $\$ 115 /$ ha for preservation, $\$ 50$ and $\$ 150 /$ ha for agroforestry, and $\$ 560$ and $\$ 1,060 /$ ha for industrial plantations. These costs are for direct expenses (e.g., seedlings, extension, management) and do not account for institutional constraints (c.g., land tenure arrangements); the need 1 ) purchase land; and other location specific factors. In comparing among the three land-use options, industrial reforestation is perhaps the most easily implemented, although the cost per tonne of sequestered carbon is higher $(\$ .1$ to $\$ 22 /$ tonne) than for preservation (\$3 to $\$ 15 /$ tonne) and agroforestry (\$2 to $\$ 10 /$ tonne). However, implementing any of these land-use options will depend on population density and rates of population growth (natural growth, migration, or resettlement) as well on other factors, such as customs and policies affecting the allocation of land and tenure, access to markets (i.c., infrastructure), foreign debt, government policies designed to generate foreign exchange from cash crops and timber exprorts, the availability of inputs and local technical skills for intensifying agriculture, and the adequacy of institutions to manage these problems.

Several general land-use policy recommendations can be made on the basis of these findings, although specific policy recommendations are not appropriate given the very broad and general scope of this study. First, the Congo basin of Central Africa shelters an cnormous poot of carbon in vegetation. The countries of Zaire, Gabon, Angola, Central Africa Republic, Cameroon, and Congo contain over half the forest carbon of Sub-Saharan Africa - about 30,000 million tonnes of carbon. Due to inaccessibility and fairly low population pressures, this pool is still largely intact. However, it could suffer the fate of the Amazon basin with similar carbon emissions if transportation access improves and governments do not recvaluate their overly lenient timber coneession policies. Policies that promote the maintenance of this carbon pool, such as controlled logging, reforestation, reduction of agricultural and fuelwood pressures, should be pursued. Second, the information base upon which to develop sound specific policies is extremely limited for Central Africa. Development of that information base should take high priority. Finally, as elsewhere in the tropics, deforestation in Sub-Saharan Africa is driven by agriculture, fuelwood needs, and international wood markets. These issues must be addressed if deforestation is to be suceessfully controlled and reforestation or afforestation implemented.

The analysis of the energy sector in Sub-Saharan Africa indicates that fossil fucl carbon emissions do not and probably will not play a major role in global carbon inventory changes. Huwever, it is also apparent that cmissions could be reduced through a variety of energy conservation and fuel substitution programs. While energy conservation and efficiency programs could not be justified in terms of reducing global carbon emissions, these programs often represent sound financial and economic investments for energy sector institutions. Investments in power-plant rehabilitation, line-loss reduction, and end-use conservation may have the effect of reducing fuel costs, reducing outlays for capital equipment, and, of course, concurrently reducing emissions from utilities and large industries.

Similarly, transportation efficiency programs reduce the amount of exhaust gas emissions per passenger mile. Stove efficiency programs may provide a deforestation credit, as well as reduce household emissions of carbon. Power sector development programs with greater emphasis on hydropower and renewable fuels may have significant impacts on future emissions, but it should be noted that overall power sector reliability will require a fixed percentage of firm capacity. As demand grows for electric energy and as consumer needs and 
expectations evolve with respect to reliability, electric power utilities will be forced to invest in both thermal and hydro resources. Investments in hydroelectric power generation appear to be the most attractive non-fossil technology option, from a resource availability perspective. Power generation from biomass resources could be pursued in selected areas where waste products are abundant, but with respect to global emissions, these options are relativcly insignificant. 


\section{INTRODUCTION}

This study addresses Sub-Saharan Africa's potential to reduce greenhouse gas fluxes, principally carton dioxide. Management of vegetation and fossil fuel trends are evaluated, with the former receiving the major amphasis. The study also estimates the costs of land-use management options for reducing carben emissions and increasing inventories of carbon from vegetation. Specific land-use management options that are analyzed include preservation (decreasing deforestation and degradation), agroforestry and fuelwood, and industrial wood plantations. In general, this study addresses the magnitude and context of Sub-Saharan carbon emissions iiom vegetation and the energy sector, the effect of laud-use management options on reducing carbon emissions and the likely effectiveness of these options, and the implementation costs of virious mitigation strategies.

\subsection{DESCRIPTION OF THE SIUDY AREA}

Sub-Saharan Africa (Fig. 1) is more than two and one-half limes larger than the United States and is occupied by many nations, ecological zones, and socioeconomic regions. ${ }^{1}$ Development concerns are enormous -15 out of the world's top 20 poorest countries in per capita income are found in the area. Sub-Saharan Africa is not only complex but dynamic. Important changes involve population, rural land use, urbanization, and energy development. The region is also one of the most poorly understood areas of the world with respect to landuse change, degree and quality of vegetalive cover, and natural resource depletion. With the world's third largest area of moist tropica! forest and the world's largest area of open forest and savanna-woodland, it is imperative to better quantify the trends and risks associated with changes in vegetative cover and carbon dicxide emissions.

\subsection{JUSTIFICATION FOR CARBON DIOXIDE EMPHASIS}

Current estimates of greenhouse gas emissions from Africa strongly suggest that anthropogenic emissions of methane, nitrous oxides, and chlorofluorocarbons are minor in both a global and a regional context. This study, therefore, concentrates on the most significant of the region's greenhouse gases, carbon dioxide, which is released when land with a high carbon inventory (i.e., forest) is converted to a land use with a low carbon inventory (i.c., agriculture) or when fossil fuels are burned. Burning of savannas was not analyzed because, although annual burning of savannas and grasslands releases enormous amounts of $\mathrm{CO}_{2}$, this $\mathrm{CO}_{2}$ is presumably taken out of the atmosphere as vegetation grows back. Thus, savanna burning is not a net carbon emitter unless the repeated burnings or excessive grazing greatly reduce the average carbon inventory. Since savannas do not store large amounts of carbon per unit area of land, degradation would have to be quite extreme for the carbon loss to be significant.

${ }^{1}$ The geographic area included in the study is all of continental Africa and Madagascar except the North African countries of West Sahara, Morocco, Tunisia, Algeria, Libya, and Egypt. Because of data limitations, some countries were excluded from spe ific analyses. 


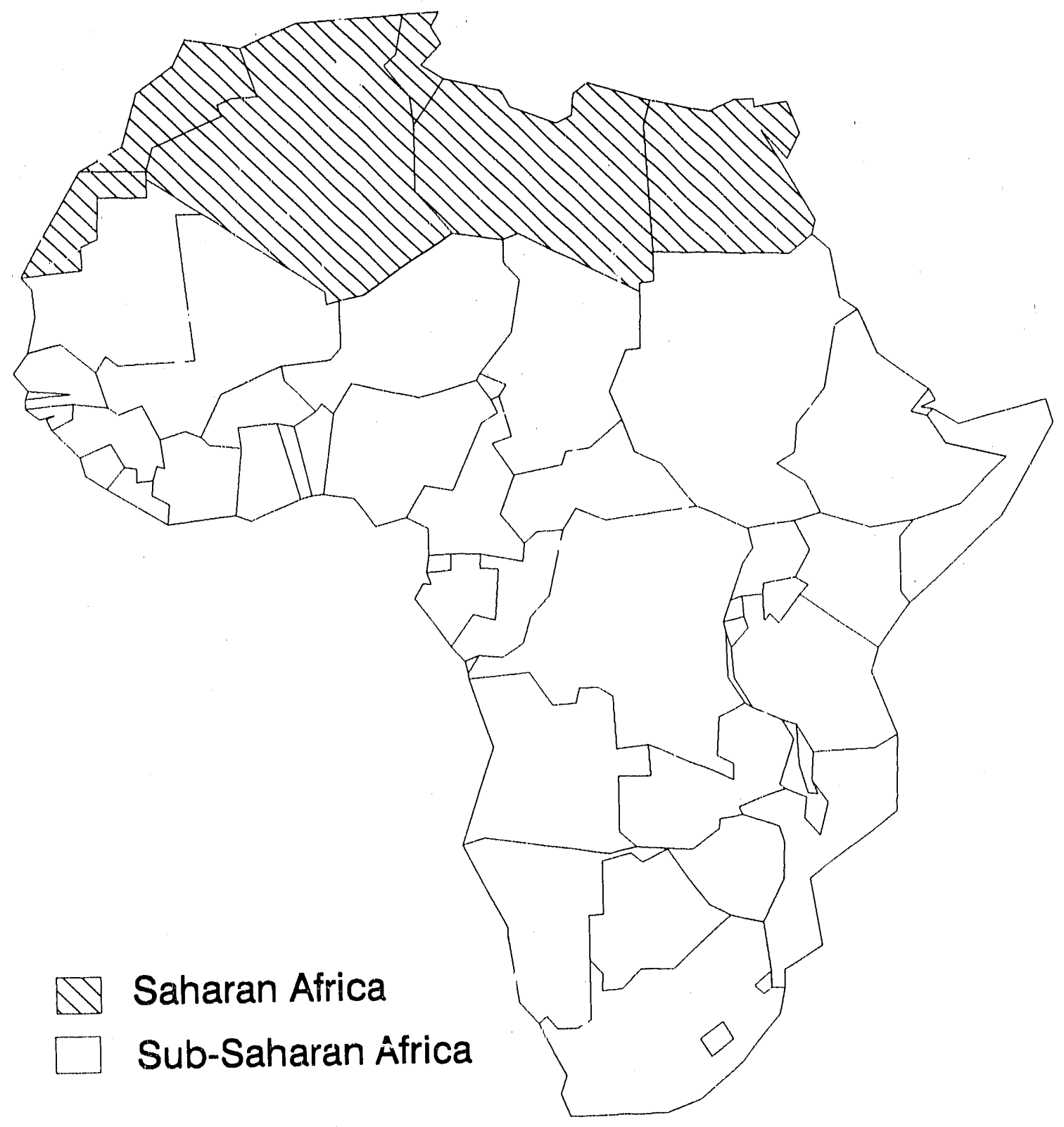

Fig. 1. Countries included in this study. 


\subsection{GENERAL APPROACH}

The methodology and scope of the land-use (vegetation) analysis explicitly ties carbon emissions to land-use change (vegetation change). ${ }^{2}$ By linking the carioun storage vialue of different land-use types to changes in the extent of those types, net carbon fluxes from landuse change are calculated. Three land-use categories (forest, forest-fallow agriculture, and nonforest) and their associated carbon storage are traced from 1985 to 2001 at 9000 point locations in Sub-Sarahan Africa. At each point, carbon emissions from changes in the extent of the different land-use classes are calculated as the difference in carbon storage over time. From these point values of carbon storage and emissions, total changes in carbon storage and emissions are compiled by country and zones within countries. Current land-use change is charack zed by Food and Agriculture Organization of the United Nations (FAO) statistics on country-specific deforestation rates. Current land use is characterized by FAO vegetation maps and FAO country-specific statistics on forest and forest-fallow area. Carbon storage values are charasterized by algorithms relating carbon storage value to vegetation type, soil fertility, annual rainfall, and likelihood of degradation. Soil fertility, annual rainfall, and likelihood of degradation are characterized by FAO maps of climate, soil types, and vegetation. To spatially synthesize the many data sources, a geographic information system (GIS) is used. Because of the great importance of the Congo Basin moist tropica! forest, remote sensing imagery is analyzed to examine deforestation processes in a few locations in Zaire and the Central African Republic.

Scale is one issue that is key to evaluating land-use management options to control carbon emissions and increase carbon inventory. Carbon inventory and land use must be linked to the local factors controlling them. National or continental statistics on land use or carbon storage are of little help in appreciating land trade-offs and management options unless they are linked with specific processes and characteristics of change at the local level. By modiling land-use change at thousands of locations, the methodology employed to analyze biomass carbon balances explicitly incorporates this concern.

I. arddition to the land-use analysis, an energy-sector analysis is made for all countries in Sub-Saharan Africa including South Africa. United Nations data of national fossil fucl

\footnotetext{
${ }^{2}$ Vegetation can play two distinct roles with regard to the control of atmospheric carbori. The first is vegetation's role in storing or sequestering atmospheric carbon. Because vegetation contains carbon and obtains carbon from the atmosphere, vegetation changes affect atmospheric carbon. If the amount of vegetation increases, carbon is lost from the atmosphere, i.e., the vegetation is sequestering carbon from the atmospheric carbon. Even if the amount of vegetation does not change, vegetation still stores carbon. 'The second role is the use of vegetation-derived fuels to displace fossil fuel use, thereby reducing fossil fuel carbon emissions. The burning of vegetation-derived fuels (biomass fuels) such as fielwood or charcoal has no net effect on atmospheric carbon concentrations as long as the b.omass fuel is replaced by rew vegetation of an equivalent carbon content. This study addresses the first role, that of sequestering carbon. Because fossil fucl use is relatively minor in drsveloping countries in Sub-Saharan Africa, its displacement with biomass fuel holds little immediate benefit. Also, virtually all fossil fuels are in the transportation and power sectors, which are very unlikely to substitute biomass as a fucl source.
} 
emissions for 1987 are assessed and preliminary projections are developed to determine the region's relative role for fossil fuel emissions.

\subsection{STUDY TEAM ORGANIZATION}

Oak Ridge National Laboratory (ORNL) managed and directed the research effort, with other institutions playing major roles due to the multidisciplinary nature of the study. The Africa Bureau of the U.S. Agency for International Development (A.I.D.) provided financial and technical support, and Miami University (of Ohio) provided land-use arialysis support. ORNL conducted the carbon inventory and land-use and economic analysis, contributed expertise from the U.S. Department of Energy's Biomass Production Program, and provided greenhouse gas emission data from the U.S. Department of Energy's Carbon Dioxide Information Center. The biomass carbon balance portion of the study was accomplished with the assistance of subcontracts with the University of Maryland (Dr. Chris Justice); Indiana State University (Drs. Paul Mausel, Susan Berta, and John Harrington, Jr.); and ESRI Company. Dr. Justice provided the vegetation map of Africa and provided information on the extent and boundaries of the closed forest of central equatorial Africa using AVHRR satellite imagery. Dr. Justice also assisted in developing the strategy for using satellite imagery and provided the SPOT imagery used in analyzing land-use change in Zaire. Drs. Paul Mausel, Susan Berta, and John Harrington were responsible for the forest-change analysis of Landsat imagery in the Central African Republic and Zaire. ESRI Company provided the GIS files of political boundaries of Africa and point locations, the flat files containing the rainfall, and the soil unit classes extracted from digital versions of the FAO maps of climate and soil units. ESRI had developed these digital files for FAO in 1985 (ESRI 1985).

\subsection{REPORT ORGANIZATION}

This report is divided into topical chapters starting witi a brief description of greenhouse gas emissions, climate change, the carbon cycle and land use as they relate to SubSaharan Africa. The study region's fossil fuel and fuclwood emissions are presented in the next chapter. The analysis of energy-sector emissions is followed by a detailed chapter on biomass carbon balances. This chapter dascribes the methodology, data, and modeling techniques used in defining land-use dynamics in the Sub-Saharan region, discusses land-use and economic factors influencing carbon emissions and their related costs, and relates the findings of the imagery analyses. The final chapter presents conclusions and discusses study limitations. Within the appendixes are energy conversion factors, tables on country energysector statistics and a comparison of FAO and AVHRR-based vegetation maps. 


\section{GREENHOUSE GASES AND VEGETATION IN SUB-SAHARAN AFRICA}

\subsection{THE GREENHOUSE CONCEPT}

Greenhouse gases act like a semipermeable membrane in the atmosphere that allows energy from the sun to pass through the atmosphere almost uninhibited (except for some reflectivity from clouds and the earth itself). As this energy warms the earth's surface, heat is reradiated back into the atmosphere as infrared radiation. Greenhouse gases absorb much of this infrared radiation, building up the heat in the atmosphere and preventing its escape into space (Solomon et al. 1985). This concept is real and has been verified on a global basis by the atmospheric temperatures of Venus, Earth, and Mars. Without the greenhouse effect, the temperature of Earth would be $33^{\circ} \mathrm{C}$ colder, preventing the development of most life forms (Schncider 1989).

While there is unanimity among the scientists that an increased concentration of greenhouse gases will result in a warmer climate, uncertainty exists in predicting the magnitude and timing of the warming. Geneial circulation models (GCMs) indicate that a doubling of carbon dioxide, or an equivalent total increase of all other greenhouse gases, would warm the earth's average surface temperature by 3.0 to $5.5^{\circ} \mathrm{C}$ (Schneider 1989). However, the current ability of GCMs to accurately predict climatic change is debatable. The coarse spatial resolution of GCMs grossly simplifies or ignores important atmospheric processes such as turbulence, cloud formation, and precipitation that occur on a scale of tens to hundreds of kilometers. ${ }^{3}$ The coarse scale of the GCMs may hide the nature of feedback loops that could either amplify or moderate the climatic change. Also, the treatment of oceans (important regulators of climate) by the GCMs is not sufficiently rigorous (Schneider 1989).

The atmospheric concentrations of the earth s greenhouse gases have been increasing at a rate faster than in the geologic past. The gases of main concern arc carbon dioxide, chlorofluorocarbons (CFCs), methane, and nitrous oxide. Table 1 summarizes the relative importance of each of these gases and the rate at which each is increasing in the atmosphere. Table 2 summarizes the current anthropogenic emissions of each of these gases. These emissions are above and beyond the natural cycling of greenhouse gases, which can be large as with carbon dioxide (over 50 billion tonnes C/year) ${ }^{4}$ or nonexistent as with chlorofluorocarbons.5 These anthropogenic sources of gases are believed to be causing the changes in atmospheric concentrations.

\footnotetext{
${ }^{3} \mathrm{GCMs}$ model global climate by simulating climate in large grid cells. Each grid cell encompasses thousands of square kilometers of the earth's surface.

${ }^{4}$ In this study the term tonne always denotes metric tonne $\left(10^{6} \mathrm{~g}\right)$.

${ }^{5}$ Each seasonal cycle of vegetation growth and death causes large positive and negative fluxes of atmospheric $\mathrm{CO}_{2}$. What is of interest, of course, is the anthropogenic flux which, although smaller, is always positive.
} 


\begin{tabular}{||l|r|r|r|r||}
\hline \multicolumn{5}{|c|}{ Table 1. Characteristics of the major greenhouse gases } \\
\hline Gas & $\begin{array}{l}\text { Atmospheric } \\
\text { concentration } \\
(\mathrm{ppm})\end{array}$ & $\begin{array}{c}\text { Annual } \\
\text { increase } \\
(\%)\end{array}$ & $\begin{array}{c}\text { Life span } \\
(\mathrm{yr})\end{array}$ & $\begin{array}{c}\text { Relative effect }^{\mathrm{b}} \\
(\mathrm{CO}=1)\end{array}$ \\
\hline $\mathrm{CO}_{2}$ & 351.3 & 0.4 & $250^{\mathrm{c}}$ & 1 \\
\hline $\mathrm{CFCs}$ & .00022 & 5 & $10-120$ & 22,000 \\
\hline $\mathrm{CH}_{4}$ & 1.7 & 1 & 10 & 30 \\
\hline $\mathrm{NO}$ & 0.31 & 0.3 & 150 & 200 \\
\hline
\end{tabular}

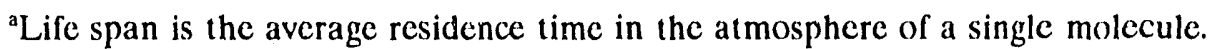

'Relative effect is the relative heat trapping capability of one molecule of a gas compared to $\mathrm{CO}_{2}$. For instance a $\mathrm{CFC}$ molecule has 22,000 times the warming effect of one molecule of $\mathrm{CO}_{2}$.

${ }^{\text {C}}$ Carbon dioxide is a stable molecule in the atmosphere, in contrast with the other, more chemically reactive, greenhouse gases listed here. Rather than being removed by chemical reactions in the atmosphere, $\mathrm{CO}_{2}$ is removed by exchanges with the oceans and terrestrial biosphere. While Ramanathan et al. (1985) and Flavin (1989) estimate the average residence time of atmospheric $\mathrm{CO}_{2}$ to be $2-4$ years, recent carbon-cycle modeling [unpublished data from William R. Emanuel of Oak Ridge National Laboratory, based on the model described in Killough and Emanuel (1981] indicates that, following the cessation of anthropogenic $\mathrm{CO}_{2}$ emissions, it would take approximately 250 years for the concentration of $\mathrm{CO}_{2}$ to be reduced by two-thirds, as a result of transfer to the oceans.

Source: Modified from Flavin, DOE. 1990. Energy and Climate Change: Report of the DOE MultiLaboratory Climate Change Committee. Lewis Publishers, Chelsea, Michigan. 


\begin{tabular}{|c|c|c|c|c|}
\hline Source & $\begin{array}{c}\mathrm{CO}_{2} \\
\left(10^{6} \text { tannes } \mathrm{C}\right)\end{array}$ & $\begin{array}{c}\mathrm{CH}_{4} \\
\left(10^{6} \text { tonnes } \mathrm{C}\right)\end{array}$ & $\begin{array}{c}\mathrm{N}_{2} \mathrm{O} \\
\left(10^{6} \text { tonnes } \mathrm{N}\right)\end{array}$ & $\begin{array}{c}\text { CFCs } \\
\left(10^{6} \text { tonncs }\right)\end{array}$ \\
\hline Pinergy (total) & $4846^{\mathrm{b}}$ & .50 & $4.0^{\mathrm{c}}$ & -81 \\
\hline \multicolumn{5}{|l|}{ Production } \\
\hline Gas & 96 & 20 & - & . \\
\hline Coal & - & 10 & .. & - \\
\hline Storage & - & $\therefore$ & - & - \\
\hline End use & & & & $\therefore$ \\
\hline Residential/commercial & & 20 & 0.4 & - \\
\hline Industrial & $34000^{d}$ & - & 1.2 & - \\
\hline Transport & & - & - & - \\
\hline Utilities & 1350 & - & 2.4 & - \\
\hline I and-use changes & 1300 & 20 & 0.5 & - \\
\hline Agriculture (total) & $\therefore$ & 175 & 2.7 & - \\
\hline Savanna burning & - & 30 & 0.4 & - \\
\hline Rice & - & 70 & - & - \\
\hline Fertilizer & - & - & 0.8 & - \\
\hline Cultivated soils & - & $\therefore$ & 1.5 & - \\
\hline Cattle & - & 75 & - & \\
\hline $\begin{array}{l}\text { Chemical manufacture } \\
\text { (total) }\end{array}$ & - & - & - & 0.77 \\
\hline Refrigeration & - & - & - & 0.25 \\
\hline Foam-blowing uses & - & - & - & 0.24 \\
\hline Acrosol spray uses & - & - & - & 0.24 \\
\hline Miscellaneous uses & - & & - & 0.05 \\
\hline Grand Toxal & 6146 & 24.5 & 7.2 & 0.77 \\
\hline
\end{tabular}

${ }^{a}$ Dashes denote zero or not significant.

${ }^{b}$ The total (4846) is probably an underestimate. Current fossil fucl carbon emissions are $~ 55010^{6}$ tonnes C.yr.

"This value is based on erroneous sampling techniques and is probably much lower (sec discussion).

${ }^{\mathrm{d}}$ Residential, Commercial, and Industrial sources are aggregared.

Source: Modified from Darmstadter, J., and J. Edmonds, Human Development and $\mathrm{CO}_{2}$ Emissions: Current Picture and I long-T'erm Prospects. In N. J. Rosentyerg et al. (eds.), Grecnhouse Warming: Abatement and Adaptation, I 88. 
Of the four leading greenhouse gases, only CFCs are man-made chemicals with no natural emissions source. CFC's are used primarily in refrigerants and aerosols (Tabile 2). Presently, CFCs come predominately from developed countries, although the potential exists for greater emissions of CFCs from developing countries in response to wider use of refrigerants and acrosols (Fig. 2). Methane comes from a wide variety of natural, seminatural, and anthropogenic sources. Of the anthropogenic sources, ruminants (cattle), rice production, fossil r.els, and biomass burning are the most important (EPA 1989, DOE 1990). As might be expected, given many diffuse sourecs of methane, statistics on methane production are quite imprecise. The values listed in Table 2 have uncertainty estimates of \pm 40 to $50 \%$ (DOE 199)). Approximately 50\% of these emissions are from developing countries (EPA 1989). Atmospheric nitrous oxides originate from the burning of fossil fucls, soil cultivation, use of fertilizers, biomass burning, and land clearing. Again, these emission estimates are fraught with large uncertainties $( \pm 50$ to $100 \%$ ). Fossil fuel combustion has been traditionally cited as the dominant source of nitrous oxide emissions (EPA 1989), but more recent work (Cicerone 1989) indicates that the fossil-fuel contribution and the contribution from biomass burning may be much less than previously thought because the technique formerly used to sample nitrous oxide concentrations had an artifact that caused concentrations to be grossly over estimaled.

Global carbon dioxide emissions are an order of magnitude larger than the emissions of any other greenhouse gas. Carbon dioxide accounts for approximately half the anticipated atmospheric warming from greenhouse gases. Even though the gas is the least active per molecule of the gases mentioned, the large quantities produced by fossil fuel combustion, cement manufacturing, gas flaring, and deforestation make this gas predominant in atmospheric warming. The concentration of $\mathrm{CO}_{2}$ has increased from about 280 parts per million (ppm) in 1750 to about $350 \mathrm{ppm}$ at present (DOE 1990). It is estimated that atmospheric concentration of $\mathrm{CO}_{2}$ will reach about $600 \mathrm{ppm}$ near the end of the 21 st century. As might be expected, deforestation contributions are almost entirely from developing countrics. Northern temperate and boreal forest may be actually sequestering carbon dioxide (Detwiler and Hall 1988). Fossil fuel emissions are largely from developed countries (EPA 1989). The estimate of carbon emissions from fossil fuel is reasonably accuratc, within $\pm 10 \%$ (EPA 1989). The estimate of carbon dioxide emissions from deforestation (i.c., land-use change) is much less certain. Recent estimates range from a high of 4200 million tonnes of carbon to 4(\%) million tonnes (Houghton et al. 1985a, Houghton et al. 1987, Detwiler and Hall 1988). The most recent report states that carbon dioxide emissions from tropical deforestation are at least 400 million tonnes C/year but not more than 1600 million tonnes (Detwiler and Hall 1988). The wide range exists because of uncertainties about the following factors: the current extent of tropical forests, the rate of deforestation, the extent of permanent conversion (many logged forests revert to secondary forests), the rate at which fallow vegetation is reverting to secondary forest, the fate of cleared vegetation, the amount of soil carbon released, the carbon content of the various types of tropical forests, and the amount of wood burned while clearing. 


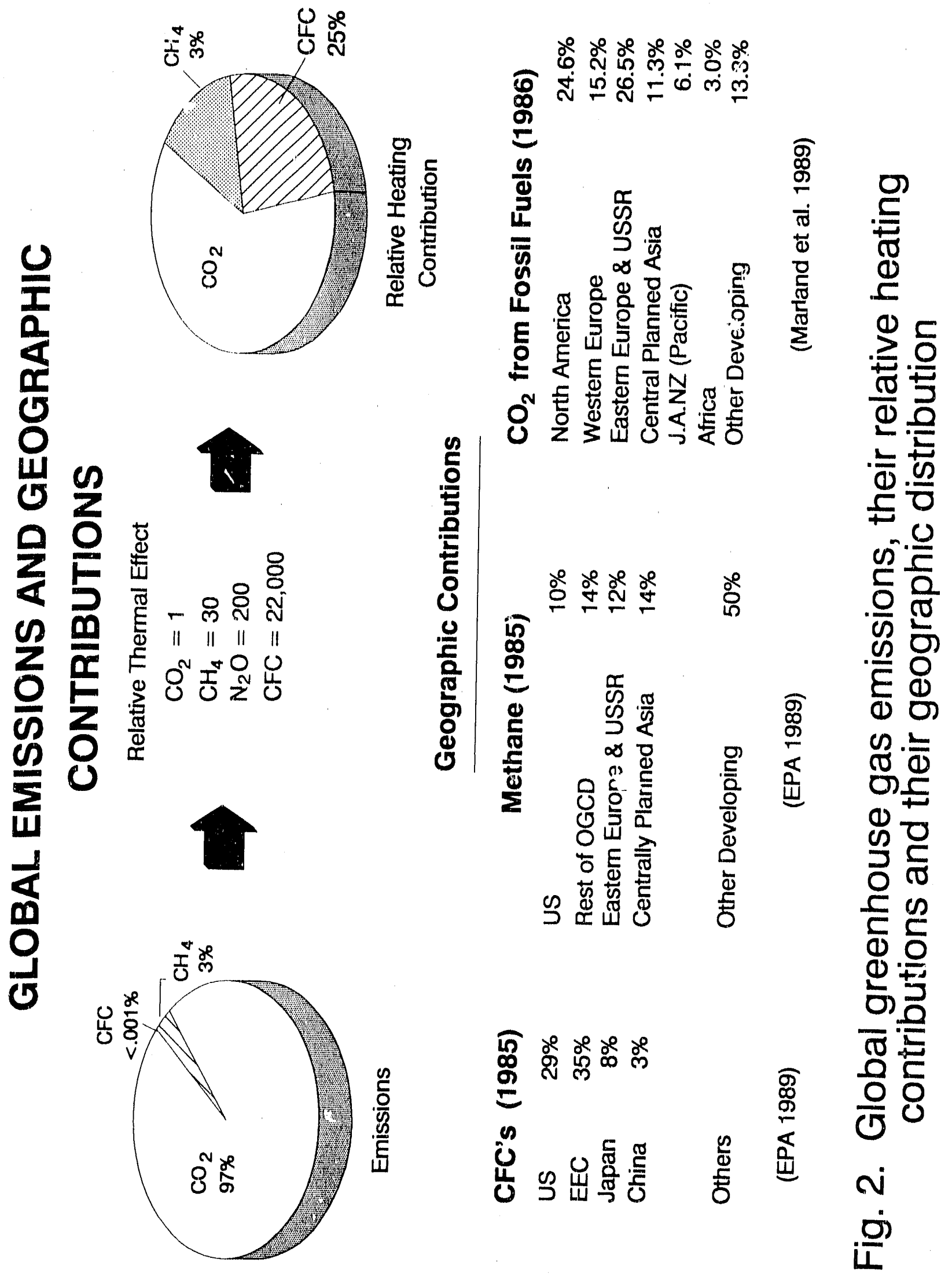




\subsection{GREENHOUSE GASES FROM SUB-SAHARAN AFRICA}

With the exception of fossii fuel consumption, CFC use, and deforestation, very little geographically explicit information exists on the sources and quantitics of greenhouse gas emissions from Sub-Saharan Africa. Thus, a quantitatively accurate assessment of SubSaharan greenhouse gas emissions is difficult. The sources of some greenhouse emissions do, how ver, shed light on the relative importance of different greenhouse gas emissions from Sub-Saharan Africa.

Because Sub-Saharan Africa (with the exception of South Africa) is largely rural and has comparatively little industrial development, greenhouse gas emissions from energy and industrial sources are low. Thus, from a global perspective, Sub-Saharan CFC emissions are negligible. As will be documented later in greater detail, fossil fucl use in Sub-Saharan Africa is negligible in a global context (Fig. 2). Consequently, nitrous oxide and methane emissions from fossil fuel use and production are also extremely low. As urban populations are rapidly increasing, the use of fossil fucls paricularly for transportation may increase greenhouse gas emissions. However, even future Africun use of lissil fucl will be quite small relative to global use. Nitrous oxide and mothane emissions from savanna burning may be significant, but quantitative information is extremely scarce (DOE 1990). Presumably, the only way to reduce such emissions is through elimination of savanna burning. Methane production by ruminants could be signilicant on a continental basis but probably not on a global basis since ruminant populations are not as high in Africa as elsewhere." Rice production, another significant global source of methane, is not grown in large quantitics in Africa.

Excluding South Africa and taking the recent estimates of carbon emissions from fossil fuel burning and deforestation in tropical Africa, it is estimated that approximately 411 million tonnes of carbon are emitted annually from Sub-Saharan Africa (Houghton et al. 1987, Marland et al. 1989). Of this, 91\% is from deforestation. Of the deforestation losses, about $40 \%$ are attributable to the destruction of elosed forest, $33 \%$ to the destruction of open forest or woodlands, and the rest to the conversion of forest fallow agriculture to permanent agriculture (Houghton et al. 1987). Data on grassland carbon dynamics are insulficient to estimate grassland contributions to carbon flux. The biomass carbon in grasslands and savanna is sufficiently low, that unless degradation was quite severe net carbon losses from these ecosystems should be small.

\subsection{C.ARBON CYCLING AND TERRESTRIAL VEGETATION}

In general, vegetation can affect atmospheric carbon dioxide in three ways. First, vegetation can grow and accumulate carbon from the atmosphere and thus effectively sequester atmospheric carbon dioxide (provided the biomass on-site continues to increase). Second, vegetation can be a source of atmospheric carbon dioxide when the biomass on a site is reduced through land-use change or degradation. Third, vegetation can be used as a

${ }^{6}$ Cattle in Sub-Saharan Africa, excluding South Africa, account for $12 \%$ of the world ruminant population. Within Sub-Saharan Africa, Ethiopia, Sudan, Tanzania, Nigeria, and Madagascar account for $56 \%$ of the cattle (WRI/LIED 1988). 
renewable fuel to displace fossil fuel and in effect recycle carbon dioxide continuously through the vegetation rather than contribute fossil fuel carbon to the atmosphere. In a region as large as Sub-Saharan Africa, all these processes can occur at once.

The relationship between carbon (carbon dioxide) and vegetation requires more explanation since not all relationships are readily apparent. These relationships are eentral to Africa's net carbon dioxide emissions. Different phenomena are involved at many levels. These include the individual plant level (e.g., growth and death), the stand and ecosystem level (e.g., biomass inventory equilibria and productivity rate), and the landscape or regional level (e.g., land-use change).

\subsubsection{Plant-Level Carbon Dynamics}

At the plant level, vegetation draws carbon from carbon dioxide in the atmosphere to produce carbohydrates through the process of photosynthesis. A substantial amount of that carbon is returned back to the atmosphere through plant respiration. The rest is used to produce biomass approximately $50 \%$ carbon by weight. Of this biomass, a considerable fraction is lost each year in the form of litter (dead ieaves branches, roots, flowers, etc). Thus, the net carbon stored in a plant (or annual growth) is a function of the amount laken in by photosynthesis minus the amount respired and the amount lost in the form of litter. As a plant matures growth slows down, consequently a young tree sequesters more carbon each year than an older tree (but the older tree contains more carbon).

\subsubsection{Ecosystem-Level Carbon Dynamics}

Like plants, ecosystems accumulate and store carbon. Likewise, for a given ecosystem type, younger ecosystems accumulate carbon at a faster rate than older ones, whereas older ones contain more carbon. Thus, in controlling atmospheric carbon, young ecosystems are useful because they sequest $\mathrm{x}$ atmospheric carbon at a very high rate, while old or mature ecosystems are uscful because they store carbon that would otherwise be in the atmosphere. Ecosystems do not accrue carbon in biomass indefinitely; eventually, respiration and mortality equal photosynthesis and the ecosystem stops accumulating more carbon. Although this point is obvious, it is also important because it limits the utility of growing vegetation (i.c., trees) for storing carbon emitted by fossil fuel burning. Eventually, the trees will mature and no longer continue to draw carbon dioxide out of the atmosphere on a net basis. ${ }^{7}$ Harvesting the site and replanting will not help unless the harvested material is stored in a way that it never decomposes.

The growth rate and carbon storage of any ecosystem is determined largely by the age of the ecosystem, genotypes (species present), climate, and soil qualitics. To the extent that humans alter any of these variables, so. will they alter the ecosystem growth rate and carbon

\footnotetext{
${ }^{7}$ The trees will, of course, photosynthesize, but release of carbon from respiration and mortality will be equivalent.
} 
storage. Of all the ecosystem types, forests store the most carbon. ${ }^{8}$ Thus the conversion of forest to any other land-use results in a net loss of carbon in vegelation and a net release of carbon to the atmosphere. Conversely, the establishment of forests on land not formerly occupied by forest is a net removal of carbon from the atmosphere.

\subsubsection{Landscape and Regional Carbon Dynamics}

Regional carbon dynamics are controlled by land use and change in land use. The conversion of high carbon storage land use to low carbon storage land use (as usually occurs with any conversion to agriculture) yiclds carbon to the atmosphere. This carbon is not necessarily released to the atmosphere at the time of land-use change. Burning will cause an immediate release of carbon dioxide, but it will also convert some of the carbon in plant matter to charcoal, which is essentially inert unless it too is burned. Material not burned will decompose into carbon dioxide at a rate dependent on the end use of the material. Plant material left on site in a tropical climate will decompose quite rapidly (days to a few years). Woody plant material used in building construction in temperate zones is estimated to take 200 years to revert to carbon dioxide (Harmon et al. 1989). In tropical countries, this reversal rate is undoubtedly much faster. Harvested forests contribute only a portion of their inventory to long-lived end products; the pereentages of bark, saw kerf, and wastes that revert to carbon dioxide quickly are high. The conversion of mature, undisturbed, well-stocked forests to commercial plantations on a sustained yicld basis will also result in a net release of carbon (Harmon et al. 1989). This process is a consequence of the carbon storage differences between undisturbed primary forests and plantations. The latter stores carbon at a much faster rate than the former but does not store as much. In summary, landscape carbon emissions from vegetation are determined by land use, land-use change, and the current and potential carbon storage of the vegetation of those land uses.

Soil carbon dynamiss may be quite important vis-a-vis $\mathrm{CO}_{2}$ cmissions. Emanual et al. (1984) and Killough and Emanual (1981) estimated 56) billion tonnes of carbon to be globally tied up in vegetation and 1500 billion tonnes in soil. However, soil carbon storage per unit land is generally low in the tropies. Alien (1985) analyzed the limited data on soil changes following deforestation in the tropics. She found that soil organic carbon decreased with deforestation especially in soils derived from old parent materials. Using a regression model, she estimated that $50 \%$ of the soil carbon in the upper $30 \mathrm{~cm}$ of such soils is lost with deforestation. This is quite significant yet from a carbon flux perspective the information must be tempered with the fact that such soils contain comparatively little carbon in the first place. Some deforestation models assume that about 30 tonnes of soil carbon are lost per

\footnotetext{
${ }^{8}$ Tropical forests contain more carbon than either temperate or boreal. Estimated carbon storagc (tonnes/ha) in forest ecosystems are: boreal forests-110 tonnes/ha, borcal woodlands80 tonnes/ha, temperate broadleaf forests 100 tonnes/ha, temperate mixed woods-100) tonnes/ha, temperate conifer forests-168 tonnes/ha, temperate forest/field complex-50 tonnes/ha, tropical wet evergreen equatorial forest 200 tonnes/ha, tropical moist deciduous/evergreen forest -140 tonnes/ha, tropical dry forest-70 tonnes/ha, tropical montane forests-90 tonnes/ha, and tropical savanna and woodland-30 tonnes/ha (derived from Olson et al 1985).
} 
hectare with the conversion of tropical forests to cropland (Houghton et al. 1987). But soil carbon dynamics are so poorly known, especially for tropical soils and in relationship to land use, that accurate modeling of soil carbon losses due to land use or land-use change is problematic. Much research is needed on this topic.

\subsubsection{Vegetation and the Global Carbon Cycle}

Sinks exist for carbon in both terrestrial and marine systems. The net exchange of atmospheric carbon with terrestrial ecosystems depends on the balance between carbon release from living and dead material (including releases due to human activity) and carbon assimilated by photosynthesis or accumulateci in marine deposits. The net exchange between the atmosphere and the oceans depands on marine biological processes, turbulent mixing, ocean circulation currents that transport carbon to deeper waters, and temperature-controlled equilibrium between carbonates and bicarbonates (Solomon et al. 1985).

Long-term studies on atmospheric $\mathrm{CO}_{2}$ indicate that $55 \%$ of the $\mathrm{CO}_{2}$ released from industrial activities remains in the atmosphere. According to the oceanic models, $35 \%$ is absorbed by the oceans. The most likely sink for the remaining $10 \%$ is vegetation. This is problematic since strong evidence exists that the present tropical deforestation is a large source of carbon (Detwiler and Hall 1988). It is not yet clear whether global vegetation as a whole is acting as a source or sink (Sedjo 1988). Some of the reasons for this uncertainty are the degree of forest recovery and regrowth in other areas (especially in the temperate regions) and the possibility of $\mathrm{CO}_{2}$ fertilization (the process of increased $\mathrm{CO}_{2}$ concentration in atmosphere leading to increased rates of photosynthesis and carbon storage) (Houghton et al. 1985b).

\subsection{FORESTS AND LAND USE IN SUB-SAHARAN AFRICA}

\subsubsection{Sub-Saharan Forests}

Sub-Saharan Africa contains the world's largest area of savarna and open woodland (an estimated 4.9 million square kilometers or $68 \%$ of the world's total) and the world's third largest closed tropical forest region (2.1 million square kilometers or $18 \%$ of the world's total) although, like elsewhere in the tropics, the original extent of the foresi has been reduced. Ghana, Ivory Coast, Liberia, Madagascar, and Nigeria formerly contained sizable amounts of closed forest. But today most of their forests have been fragmented and are in various states of degradation due to commercial, agricultural, and fuelwood pressures.

The situation in central Africa is somewhat better. The countries of Cameroon, Gabon, Congo, and Zaire have large areas of intact closed forests. Most of the forest regions of these countries are sparsely populated, and, even though shifting cultivation takes place, fallow cycles are long enough to allow adequate forest regeneration in most areas (Lanly 1982). However, since population is increasing and these forests are becoming more commercialized, these forests may encounter a fate similar to that of West African forests. In the remainder of the Sub-Saharan countries, closed forest does not occur in broad continuous belts but in isolated patches, on mountain slopes, and along some coastal regions. Except for those on inaccessible terrain, these forests have been heavily disturbed (White 1983). 
Closed-forest deforestation takes many forms in Sub-Saharan Africa. Sometimes deforestation is associated with permanent agriculture or pasture and settlement along transportation corridors as it is in Brazil. However, other times Sub-Saharan deforestation occurs as a gradual removal of forest at the forest/savanna boundary due to savanna fires and fuel wood removal. In other places it is the loss of riparian forest corridors within a savanna grassland matrix. While in still other places, it appears more as degradation, as when forests are thinned and cash crops such as tobacco or coffee are grown under a remnant tiec canopy. $I_{i i}$ yet other places, it is the shortening of fallow periods in forest fallow agriculture due to population pressures. In even other places it may occur as a consequence of logging road construction and timber harvest with no forest regeneration. Thus developing accurate rates of hectares of closed forest cleared each year and the associated vegetation loss is complicated in Sub-Saharan Africa.

The woodlands of South-Central Africa and the wooded savanna areas of West Africa and East Africa have been severely degraded due to agricultural and fuelwood pressures (Anderson 1984, 1987). Circular deforested belts can be seen around major urban centers and are caused by demand for fuclwood, charcoal, furniture, and construction (Kalapula 1989). Quantifying the loss and degradation of woodland is extremely difficult, since it is a much more subtle change than the complete removal of closed forest (which can be readily identified in aerial photography and with fine-resolution satellite imagery) (Green and Sussman 1990).

\subsubsection{Land Use Options in Sub-Saharan Africa}

Pure shifting cultivation is no longer the dominant form of agriculture in much of SubSaharan Africa. Permanent cultivation is now extensively practiced in the highland areas of Burundi, Ethiopia, Kenya, Malawi, Rwanda, Tanzania, Zambia, and near towns and villages in the Zaire basin. In West Africa, one finds rural populations supplementing their shifting agriculture with permanent plantings of rice and/or trec crops (c.g., oil palm). Shifting cultivation is only dominant in the middle belt of West Africa between the coastal tree belt and the permanently farmed northern savanna and in the sparsely populated areas of Tanzania, Zambia, Mozambique, and Zaire. Where conditions are such that population density precludes carrying on sustainable shifting cultivation or a further shortening of the fallow, subsistence farmers must adopt alternatives. ${ }^{9}$ According to the FAO (1987), a priority must be set to improve and intensify agricultural production on land suited for agriculture, thereby lessening the need to clear new lands and relieving the pressure on forests ${ }^{10}$.

\footnotetext{
${ }^{9}$ Ruthenberg calculates that no more than 56 people per square kilometer can be supported by shifting cultivation in Benin. In the Ivory Coast, population density is currently as high as 83 people per square kilometer and that as many as 123 people per square kilometer could be supported by shifting cultivation (FAO 1984a).

${ }^{10}$ Africa's current population growth rate of about $3 \%$ per year exceeds its growth in food production by $1.2 \%$ (Office of Technology Assessment 1984). The FAO (1981) projects that, given present agricultural technology and population growth rates, there will be approximately 127 million seriously undernourished people in Africa by the year 2000 .
} 
An emerging consensus suggests that the most appropriate (land-use) options lie with technologies that account for the particular needs and constraints faced by subsistence farmers (OTA 1984, FAO 1987). Given that the majority of Africa's population is rural and predominantly subsistence producers, the most appropriate technologies must be low risk, resource conserving, small-scale, noncapital i.tensive, adapted to the availability of local labor, and consistent with traditional agricultural methods. For these subsistence producers, the adoption of agroforestry practices, which take advantage of the complementary role trees have on crops, are particularly relevant. ${ }^{11}$

Agroforestry approaches that integrate trees into cropping patterns can enhance organic inatter and maintain fertility, reciuce erosion, conserve soil moisture, and create a more favorable microclimate conducive to sustainable agriculture (Raintree 1985). Moreover, these approaches can yield a host of valuable and useful by-products, such as fuelwood and animal fodder. Under a lower land-use intensity (population density), the frequency of cropping on shifting agricultural lands (i.e., intensifying shifting cultivation) can be increased. Normally, shortening of the fallow re sults in soil degradation and reduced yields; however, short fallow agriculture can be made sustainable by planting woody legumes ard cash-valued trees in lieu of natural bush regeneration. Woody legumes that fix nitrogen, grow rapidly, and establish easily can regenerate soil fertility in a reduced time period more consistent with shortened fall ow shifting cultivation. ${ }^{12}$ At higher land-use intensities, short fallow, annual cropping, and multiple cropping can be improved by spatially integrating trees in cropping patterns (e.g., alley cropping, multistory intercropping, and interstitial plantings). ${ }^{13}$ It is also practical to integrate trees into the landscape in the drier pastoral regions of Africa. In these regions, trees can help to conserve soil moisture, control wind erosion, yield fodder for livestock, and piovide a source of fuelwood and ether useful products. For example, Raintree (1986) summarizes an analysis that showed that, if all interstitial locations (e.g., boundaries, pathways, watercourses, etc.) were planted $\cdots$ ith trees and shrubs, some $50 \%$ of the fuelwood and $40 \%$ of the fodder requirements could be met with very little competition with agriculture.

In addition ' 2 promoting sustainable agriculture systems, land-use policies are required to protect and conserve remaining natural forests, to implement better management techniques for forests being exploited for timber and wood products, and, where appropriate,

\footnotetext{
${ }^{11}$ Confronting the food crisis in Africa must alsu involve making policies that increase production on lands already in permanent cultivation (i.e., modernization). Modernized agricultural systems usually take the form of developing infrastructure for pumped irrigation, increasing the efficiency of seed and fertilizer technology in dryland farming areas, adopting greater use of mechanization, and more efficiently managing rainfed systems to conserve soil moisture and fertility (Okigbo 1984).
}

${ }^{12}$ Raintree (1986) contrasts two forms of improved fallow: economically enriched and biologically enriched. Economicaliy enriched fallows would value trees for their ability to generate additional cash, whereas biologically enriched fallow would value trees for their ability to accelerate the regeneration of scil nutrients and control of weeds.

${ }^{13}$ Alternatively, taungya systems incorporate farmers into forests. 
to reforest areas tor timber and fuelwood needs. Beyond reducing development pressures (i.e., intensifying agriculture, incorporating trees into agriculture, and establishing plantations), natural forests can be better protected as a store of carbon by designating and enlarging protected areas. Greater use of multiple-use zoning on public lands and the offering of financial incentives on private land could be used to protect and expand areas of natural forests. ${ }^{14}$

Governments can also evaluate their policies on overlenient timber concessions, which would encourage more sustainable management of natural forests. Natural forests that are being exploited commercially can be better managed by examining the terms of concession agreements (length of agreement, logging practices, royalties, etc.) and by requiring or making provisions for reforestation. More appropriate policies could lessen logging-induced deforestation as well as reduce access to subsistence farmers in search of agricultural land. However, government ownership of most forest land in Africa creates certain problems relative to establishment of new forests. For example, industry may have no long-term right to the trees it plants. Where there are privately held forest lands, governments can provide incentives to encourage tree planting, ranging from favorable tax policies to subsidies for seedling production and planting.

Improved management of productive forests can also reduce deforestation pressure and help maintain stores of carbon by increasing the annual productivity of natural forests. Greater wood production is possible with improved forest management practices (Maitre 1987); for example, selective felling and thinning to climinate uneconomic species, mandatory replanting with fast-growing species in logged-over areas, rotation of extraction areas to promote regeneration, and promotion of markets for lesser-known species (i.e., greater utilization).

Reforestation of selected areas where development pressures and population densities are not high is another option for sequestering carbon. Although reforestation for fuelwood has not been consistently successful, many instances exist of government-sponsored plantings of trees for timber and pulpwood needs. Projects to encourage individual farmers to plant trees have not succeeded, owing to a lack of financial incentives (French 1986, Elkan 1988). ${ }^{15}$ Instead, agroforestry approaches that place a greater emphasis on multipurpose trees that yield a variety of products (building poles, fruit, fodder, and timber) are more promising. This latter approach encourages the development of markets for trec products and

\footnotetext{
${ }^{14}$ Wilkinson (1985) cautions that the use of legislation designed to protect forest areas has been ineffective, because these areas have not been adequately defended against encroachment.

${ }^{15}$ One option for forestry departments to reduce the costs of plantation establishment is through the taungya system, in which food crops are planted in the early years of forestry plantation establishment. Typically, farmers are required to plant trees in exchange for the right to cultivate food crops between the trees for 1 to $3 \mathrm{yr}$. The prime advantage of taungya is that it allows forestry departments to establish and maintain tree plantations at very low cost.
} 
offers free or low-cost seedlings to remove investment cost and risk barriers and may also stimulate more farmers to plant trees. 


\section{ENERGY-SECTOR EMISSIONS}

\subsection{ENERGY-SECTOR OVERVIEW}

The energy sector of Sub-Saharan Africa is underdeveloped, with the lowest gross and per capita energy consumption in the world. On a sectoral basis, hydroclectric power production provides $8 \%$ of the total energy demand; $64 \%$ of energy is supplied by biomass resources for domestic consumption; and $28 \%$ of the gross energy demand is met by petroleum products, coal, natural gas for transportation, agriculture, and industry (United Nations 1989). ${ }^{16}$

Wood and charcoal are the most commonly used biomass fuels in African households. Coal, peat, and animal dung are also used but are a very small fraction of total household energy consumption. Whereas cconomic and energy growth in several countries is high, the commercial energy consumption (energy intensity relative to industrialized countries) is very low. ${ }^{17}$ Thus, energy consumption by Sub-Saharan Africa is dominated by houschold use of biomass fucls.

Growth of energy demand depends on many factors. Assuming that growth is not supply constrained, biomass fuel consumption should grow concomitantly with population, if there are no changes in thic availability of biomass fuels (i.e., due to increasing scarcity and relative prices) or in the adoption of new and more efficient conversion technologies. Demand for fossil fuels and electricity should grow as a function of economic growth. However, data describing the relative level of biomass fuel consumption to that of fossil fuels and electricity are inadequate.

From an environmental perspective, one of the most serious issues is the growing use of biomass fuels for domestic cooking due to rapidly expanding populations. There is a direct linkage of consumption of wood and charcoal fuel to deforestation, although studies have indicated that agricultural clearing is the major cause of deforestation. A strong case can be made that fuel conservation and technology transfer can and should be a part of forest preservation strategies (A.I.D. 1988).

This chapter explores the extent to which the energy sector contributes to carbon emissions in Africa. Estimates of energy use (by fuel type and sector), carbon emissions from fucl conversion, consumption patterns by country and time frame, and projections of future consumption will be provided. Finally, options to improve energy efficiency will be described, with an estimation of their effect on future carbon emissions. The discussion closes with cemments regarding the institutional and political sensitivities that may be involved in mitigation strategies.

${ }^{16}$ Unless noted otherwise, Sub-Saharan values in this chapter include South Africa.

${ }^{17}$ Bagasse is used in sugar mills for on-site thermal loads and to satisfy on-site power demands. In some cases, bagasse power generation could provide power to surrounding areas, but this is by no means the norm. 


\subsection{CARBON EMISSIONS FROM ENERGY CONVERSION}

Several data sources were reviewed to estimate the level of energy use and the corresponding level of carbon dioxide emissions in Sub-Saharan Africa. However, the primary data source was the United Nations Data Tape, a data base of statistics compiled for all cooperating countries that is updated annually and provides energy consumption by fuel type, country, region, and sector for all recorded years dating back to 1950. Although this is a comprehensive source of information, it must be used with caution. Data provided by many developing countries can only be used to estimate general patterns of energy consumption, ${ }^{18}$ since data are fraught with errors and inconsistencies or may not have been updated or confirmed for many years. The quantitative accuracy of the data is especially problematic for biomass energy estimates. ${ }^{19}$

The methodology employed for this analysis was fairly straightforward. The 1987 U.N. Energy Statistics Data Tape was aceessed through the Carbon Dioxide Information and Analysis Center (CDIAC) at ORNL. A SAS program was used to access the tape and to perform the following two analyses. First, the production of carbon dioxide from fossil fucls and cement production was calculated and ranked in descending order. These data were calculated from fucl production data and converted to thousand metric tonnes of carbon equivalent. Analyses were performed for years including 1977, 1982, and 1987.

Second, the consumption of renewable fuels, including fuelwood and bagasse, was calculated using an 11-year time scries from 1977 through 1987 . These values were then converted to equivalent carbon dioxide emissions, in million metric tonnes of carbon.

These two analyses were combined to form a uniform spreadsheet of carbon dioxide cmissions for biomass and fossil fucl consumption in Africa for 3 ycars (including 1977, 1982, and 1987) for each country. The spreadsheets were modified, deleting Saharan nations (Morocco, Tunisia, Algeria, Libya, and Egypt) and South Africa. The South Africa fuel consumption totals are so drastically different from other Sub-Saharan African countrics that it was deemed important to illustrate the energy-use levels with and without this country.

An attempt was made to perform a comparative sectoral analysis with information from World Bank Energy/Strategy Management and Assessment Program reports, but the information available in these reports was insufficient to complete the analysis for the selected countries. The reports were used, however, to provide information on characteristics of sectoral energy demand.

${ }^{18}$ Fossil fuel production and consumption figures are thought to be reasonably accurate. Biomass fuel consumption is much more problematic, due to the nature of informal trade patterns between suppliers and consumers. The degree of uncertainty in data estimates is thought to be as high as $400 \%$.

${ }^{19}$ There is no single source of dependable, accurate data for biomass fuel consumption in Africa. In a number of cases, surveys have been completed within countries that have been well received by development agencies (for countries such as Kenya and Ivory Coast), but this certainly has not been done on a continental or regional basis (Jones 1989). 
A final review of power-sector statistics was performed to characterize electricity supply in each respective country by reviewing information provided in the U.N. Energy Statistics Yearbook. The U.N. Energy Statistics Data Tape is the source of this information, but the yearbook already has the information formatted in casy-to-use form (it was clearly easier to use this than to write a separate SAS program to access power sector information).

Dimensions describing energy values provided by the tape vary by fucl type. For example, fuel wood consumption is provided in cubic meters, whereas bagasse is provided in tonnes. As a part of the analysis performed for this study, all energy values were converted from base dimensions used in the data tape to tonnes oil equivalent (TOE); all carbon values are presented in tonnes. Conversion factors used are provided in Appendix 1.

\subsection{FINDINGS}

Table 3 summarizes energy consumption for the countries included in this study for 1977, 1982, and 1987. The data reveal that South Africa uses approximately $38 \%$ of the total energy consumed by all Sub-Saharan African nations. However, South Africa consumes only $5 \%$ of the total biomass energy used in Sub-Saharan Africa. This is, of course, due to the size and more advanced nature of the South African economy compared to that of many other African economies. Comprehensive data listing energy consumption for all $r$ suntries included in the study are provided in Appendix 2.

Table 3 illustrates that the nations using the most commercial energy include Nigeria $(29,564,000)$ TOE) and Ethiopia, Kenya, Zaire, and Zimbabwe, all using between 7,600,00) and 5,300,000 TOE. All other countries consume an aggregate 56,700,000) TOE.

Table 4 summarizes power-sector characteristics for the major energy-producing countries. Note the relative roles played by hydro and thermal resources in the energy production mix: hydro supplies at least $56 \%$ of the electric energy generation (a high percentage of the self-generated energy is also hydro), whereas thermal energy contributes slightly more than $30 \%$ of electric energy in the power sector.

Another revealing statistic is the average capacity factor shown in Table 4. While the average capacity factor perhaps provides an oversimplified measure of utility-resource management, it does provide a means of drawing a gross comparison between different systems. The world average capacity factor is $47 \%$; Sub-Saharan African countries, excluding South Africa, have an average capacity factor of $31 \%$. This low capacity factor implies that capital plant is utilized over $50 \%$ less effectively than in all other countries in the world. This is due in part to the prominent role played by hydroelectric generation in the capacity mix and the seasonal effects of rainfall distribution on hydroelectric capacity. In contrast, the overall capacity factor of South Africa is $56 \%$ (with a thermally based capacity mix), much closer to that expected from a western industrialized nation. 


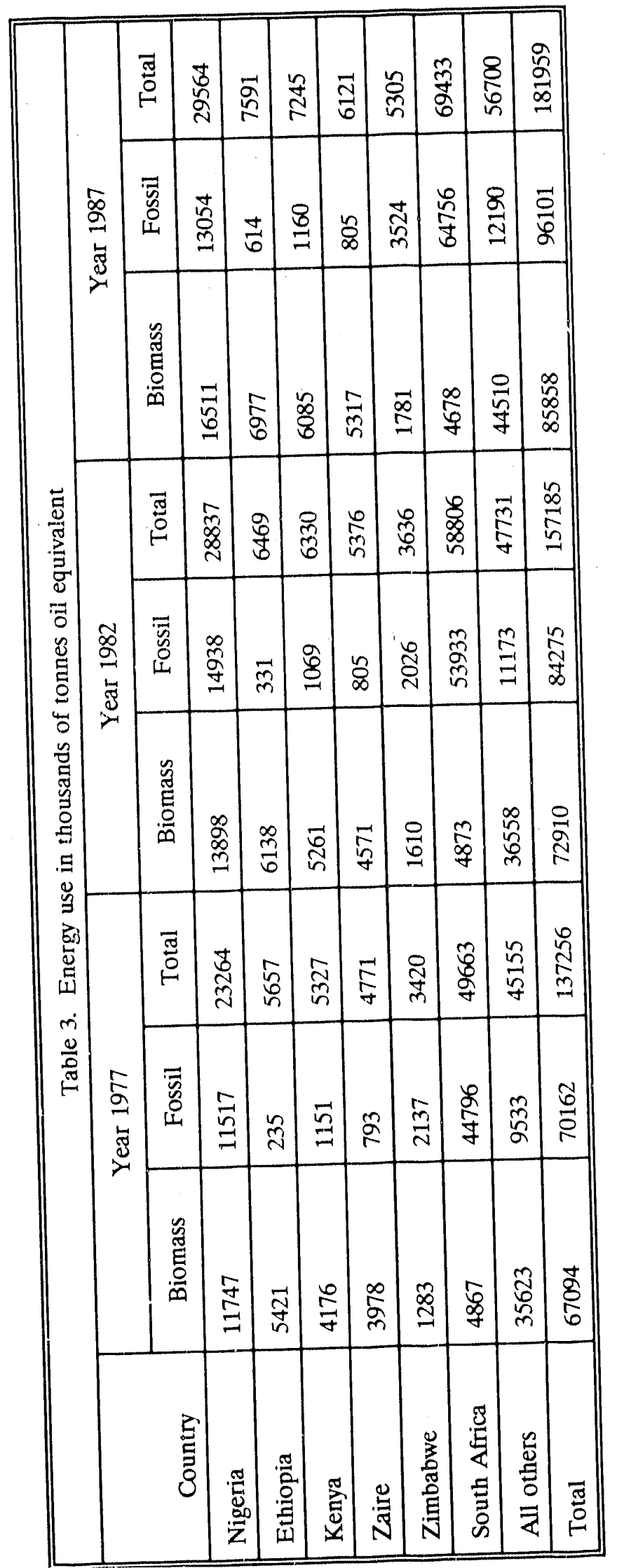




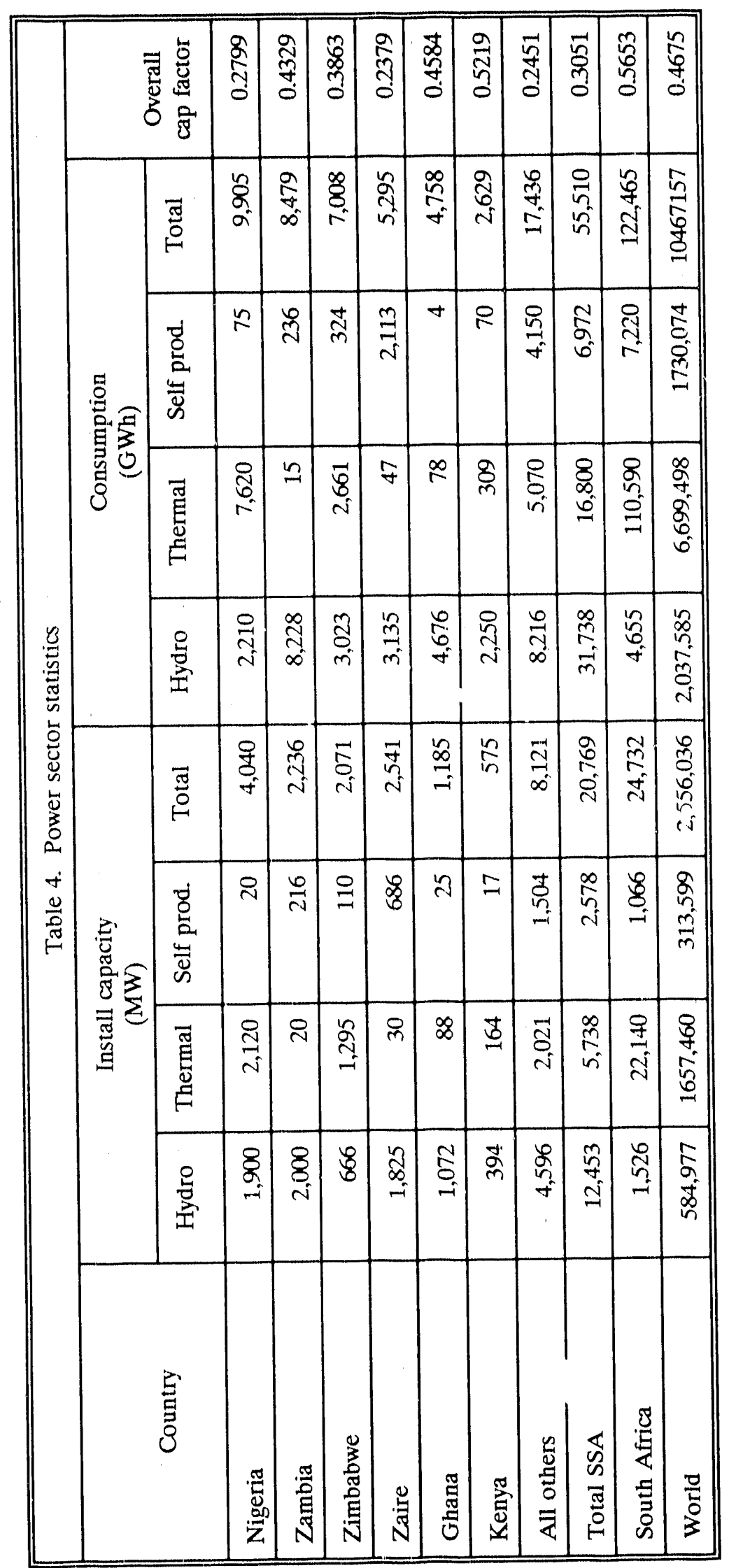


Table 5 summarizes the carbon emissions from energy conversion processes in Africa. The countries contributing most significantly include Nigeria (40 million tonnes of carbon), Kenya (10 million tonnes of carbon), Ethiopia (10 million tonnes of carbon), and Zaire (8 million tonnes of carbon). In contrast, South Africa emitted 82 million tonnes of carbon in 1987, over one-half the carbon released by all Sub-Saharan African eountries. The data show that biomass-derived fuels emit the largest fraction of carbon to the atmosphere, and the true figure could be much higher or lower ${ }^{20}$. Fossil fuels contribute a significant fraction with respect to the carbon emitted from Africa but a relatively small fraction of total world carbon emissions. Fossil fuel global emissions were estimated in 1987 to be 5,50) million tonnes of carbon, or approximately 48 times the total fossil fuel emissions by Sub-Saharan Africa in that same year and 146 times the fossil fucl emissions by developing Sub-Saharan countries.

Figure 3 illustrates the growth rate of energy consumption for the period studied and the concurrent rate of growth of carbon emissions, with projections for future emissions if the present growth rate is sustained. For illustrative purposes, a linear growth rate was assumed for energy consumption over the projected period to the year 2010. South African energy consumption is not included in this figure.

This graph demonstrates the importance of biomass emissions relative to fossil fuel emissions. This simplified projection assumes that demand will not be supply constrained due to population levels, or that the economic growth rates will not cause an appreciable shift to increased use of electricity, petroleum, natural gas, and/or coal. Typically, one would expect increased consumption of fossil fuels relative to biomass fucls with increasing economic growth.

Figure 4 provides a constrained growth secnario governed by the introduction of conservation programs. Again, South African energy consumption is not included.

Introduction of conservation programs would theoretically allow economic growth rates to be sustained, with lower energy consumption. In this scenario, it is assumed that commercial, industrial, and power-sector conservation programs would require a 5 -yr period to be designed and implemented and that $10 \%$ savings could be realized in the first $10 \mathrm{yr}$ of the program, increasing to $20 \%$ in the following $10 \mathrm{yr}$.

For biomass fuel consumption, it was assumed that the introduction of energy-eflicient stoves and charcoal kilns would result in $50 \%$ savings (from 20 to $30 \%$ efficiency for improved stoves and from 15 to $25 \%$ from earthen to steel or brick kilns). A conservative $10 \%$ market penetration was assumed in the first decade, rising to $20 \%$ in the second decade (A.I.D. 1988, Leach and Gowen 1987).

\footnotetext{
${ }^{20}$ Note that biomass emissions listed in the U.N. data base are gross emissions; the data base does not account for the absorptive capacity of the forest and grasslands in the biological carbon cycle. Presumably, most of the carbon emissions due to biomass burning are included in the estimates of carbon emissions from deforestation. It must be noted that although the fossil fuel figures presented can be verified by a varicty of means, the biomass fuel figures cannot.
} 


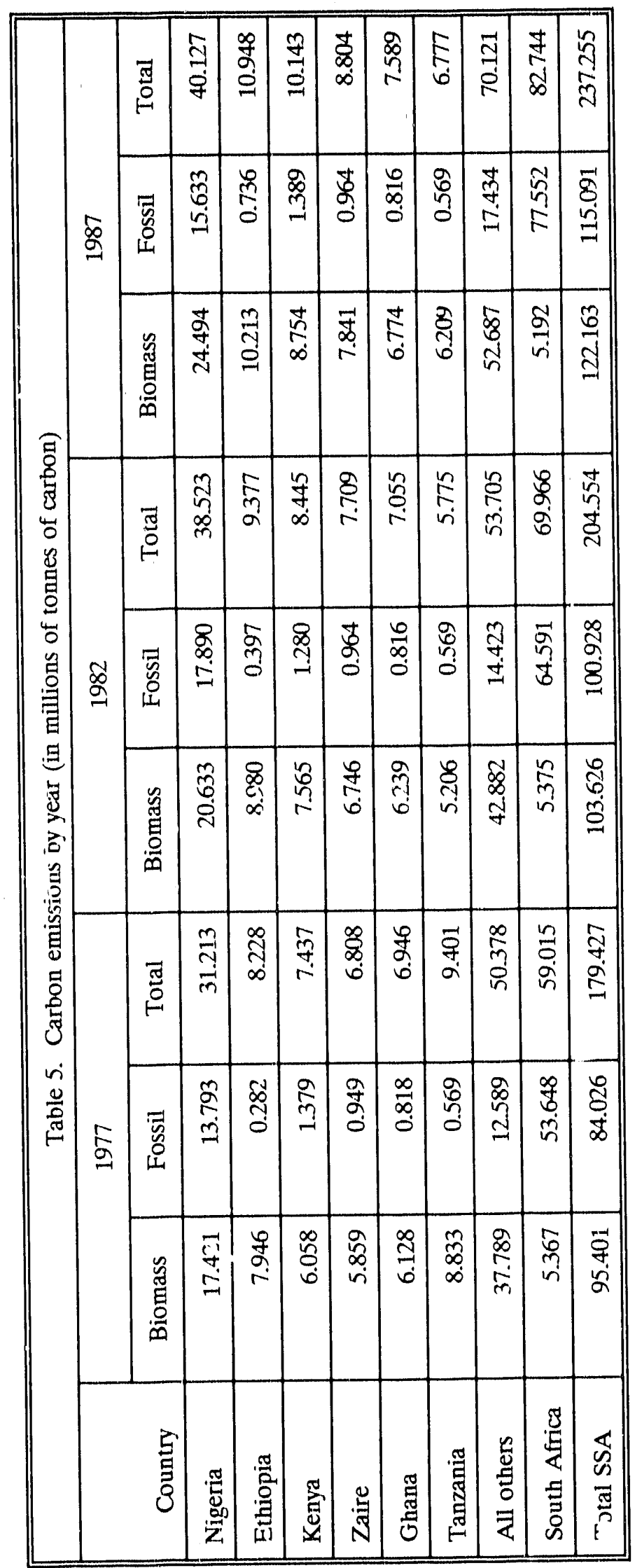




\section{ENERGY CONSUMPTION SUBSAHARAN AFRICA}

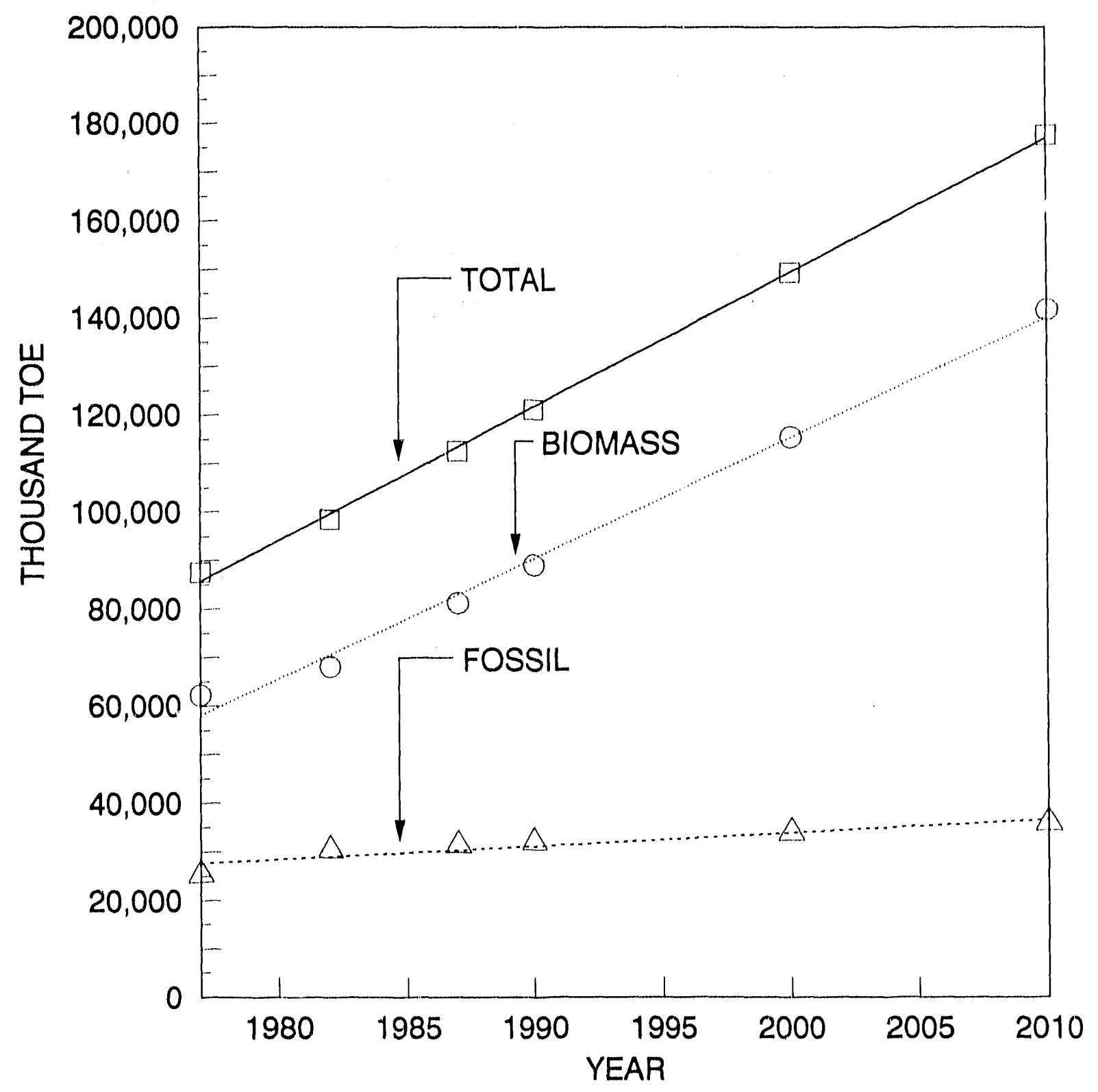

Fig. 3. Annual energy consumption in Sub-Saharan Africa assuming unconstrained growth. 


\section{ENERGY CONSERVATION SCENARIO SUBSAHARAN AFRICA}

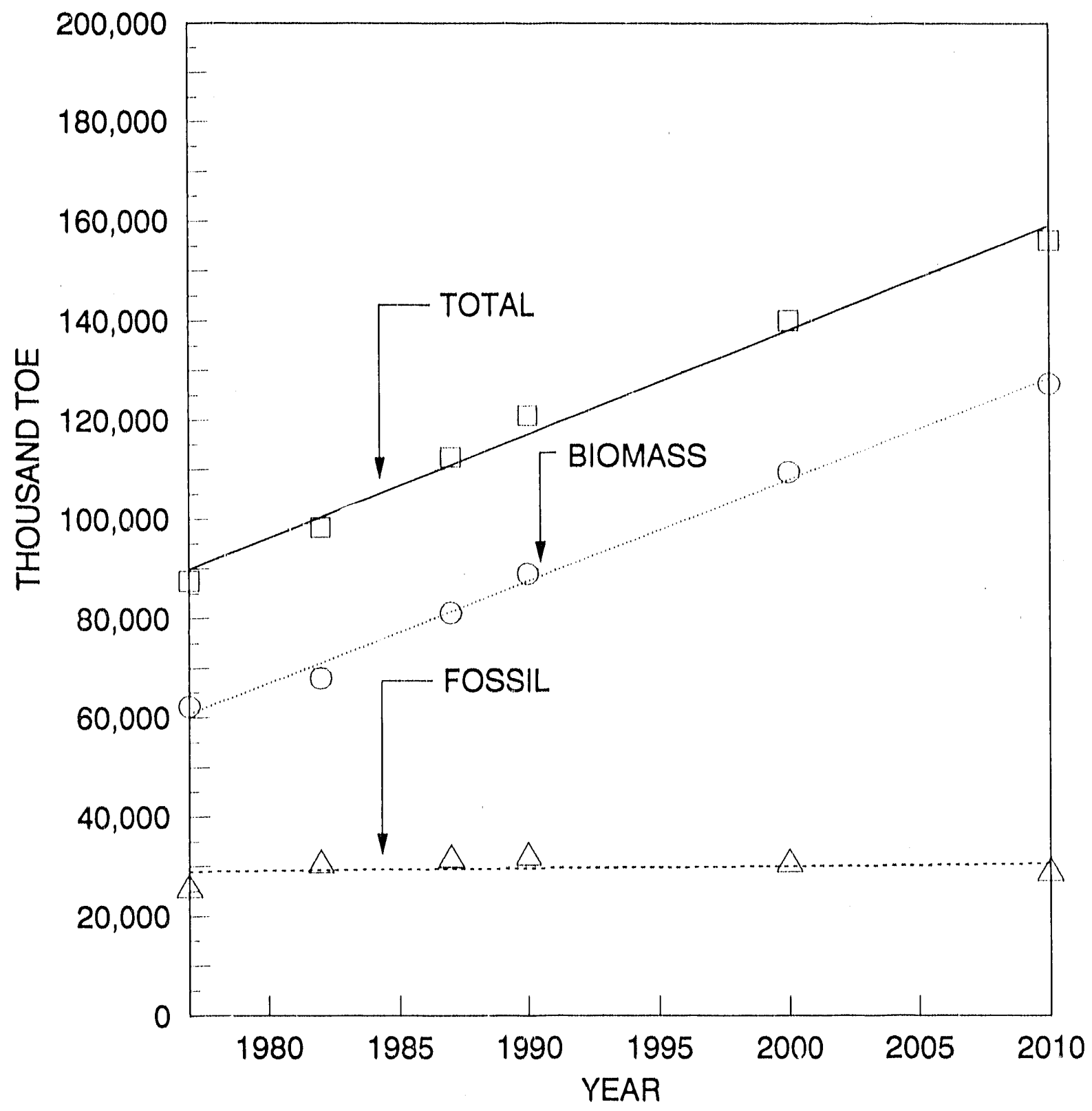

Fig. 4. Annual energy consumption in Sub-Saharan Africa excluding South Africa assuming implementation of energy conservation program. 
The power-sector demand for this scenario is slightly nugative. This result reflects a very flat demand curve for the last 10-year period and the fact that the increases in efficiency could very well make up for power-sector expansion in many countries. If economies grow more quickly than during the report period, the fossil fuel consumption curve will turn upwards, albeit with a modest slope.

Introduction of renewable encrgy conversion devices will also have the effect of constraining demand. Renewable energy conversion devices, such as wind turbines, biomass combustion equipment, and photovoltaic energy systems, are presently competitive for relatively small-scale power applications. If utility-scale applications are introduced, the maximum percentage of capacity likely to be replaced would be $15 \%{ }^{21}$ However, over a 20year time frame, it is unlikely that renewables will represent more than $5 \%$ of total installed capacity under the best of conditions. For this reason, renewables do not factor significantly into a 20 -year demand/supply forecast.

Figure 5 provides a comparison of energy-sector carbon emission projections for SubSaharan Africa relative to global projections. As this figure illustrates, Sub-Saharan Africa is not a major contributor to atmospheric carbon, nor is it likely to be in the next 20 year. Again, South African carbon emissions are not included in the Sub-Sarahan emissions.

\subsection{EMISSION-REDUCTION OPPOR'TUNITIES}

Whereas the findings presented above are not cause for alarm (considering the relative unimportance of Sub-Saharan African countries with respect to global carbon emissions) reduction opportunities do exist that could prove beneficial to participating economies along several associated fronts. These opportunities vary according to each sector of the economy affected but have a common denominator in terms of economic efficiency.

As implied in Fig. 4, conservation opportunities can contribute significantly to reduction of carbon emissions in Africa. The greatest opportunities exist in domestic cooking devices. Typical charcoal stove efficiencies approximate $20 \%$ overall thermal efficiency (A.I.D. 1988), whereas efficiencies ( Jpen threc-stone fires have been estimated between 7 and 15\%, depending upon the cooking utensil employed (Leach and Gowen 1987). Use of improved stove technology has the potential of improving efficiency to $30-35 \%$, an increase of over $50 \%$.

It is clear, however, that improvements in domestic cooking patterns will be difficult to accomplish. Institutional vehicles need to be developed, the private sector must be mobilized, and the cooking devices must present a clear and financially attractive advantage over existing devices and be consistent with local sociocultural factors. To date, there have been very few documented, successful stove programs (World Bank 1984).

\footnotetext{
${ }^{21}$ Experience in the United States has shown that use of renewable energy systems to deliver grid power has resulted in significant control challenges for electric power utilities. This has led to the assumption that no more than $15 \%$ of installed capacity should be dedicated to renewable energy resources.
} 


\section{CARBON EMISSION TRENDS}

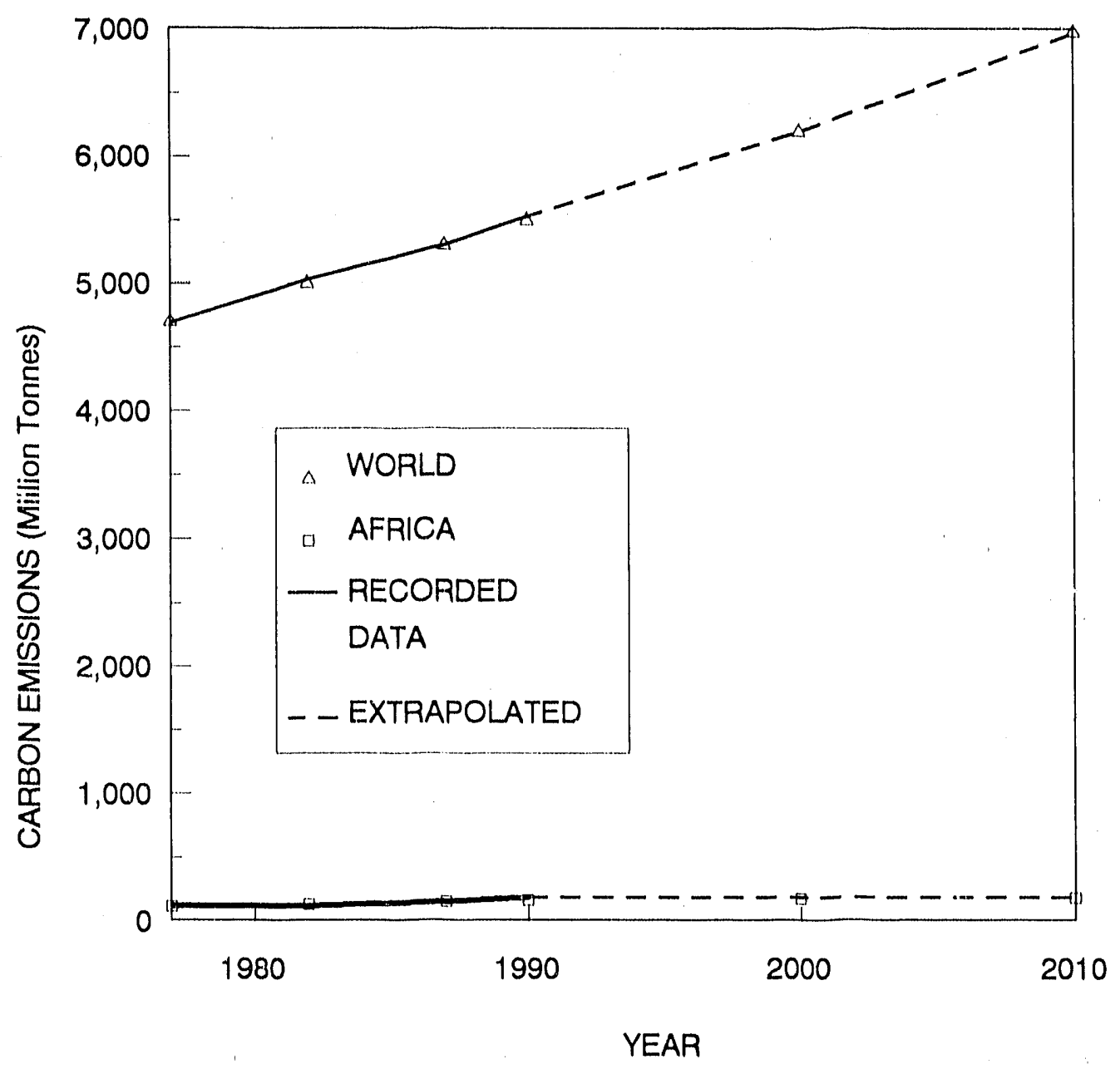

Fig. 5. Energy sector carbon emissions in Sub-Saharan Africa compared to global totals. 
Fuel substitution is another alternative that could be addressed to domestic-sector energy use, transportation, power, and industry. Fuel substitution in the power industry could yield a net gain (reduction of carbon emissions), but it has been shown that this sector is a very low contributor to carbon emissions in Africa. However, it has been noted that as little as $2.5 \%$ of the hydroelectric potential has been developed thus far, and, with the growth of international cooperation, power sales from countries with significant hydro resources (i.e., those in West and Central Africa) could result in recuced reliance on fossil fuels for electric power production. It should also be noted that many of the fossil-fired plants in Sub-Saharan Africa serve isolated syst :--s, so these plants in all probability would not be affected by a shift towards hydroelectric power production. In all likelihood, new loads could be served by hydro, whereas existing loads served by thermal plants would continue to be served in this way.

Energy savings in transportation may be the most difficult to effect through fuel substitution or conservation. It can be argued that this sector is already very fuel efficient, due to high occupancy rates (relative to western standards) of passenger and public service vchicles. Introduction of fuel substitutes, such as ethanol or methanol, is unlikely to have a dramatic effect on fossil consumption for transportation. With rather questionable economics and the complication of logistics and management, biomass-derived liquid fuels probably will not play a significant role in carbon emission reduction.

Encrgy conservation opportunitics in industrial processes abound in Africa, but again, initiating conservation programs is management and capital intensive. Many so-called energy management measures (measures directed at how processes are conducted) can provide significant energy savings at no or at low cost. Energy conservation measures, including equipment retrofits and fuel substitution, are generally more capital intensive but can provide very attractive investment options for industrial users. However, the difficulty lies both in identifying and in selling these conservation opportunities to end users; it requires commitment, strong policy support, and financial support.

Fuel substitution in the domestic sector is gaining increased attention. This is a topic of some controversy and certainly one not sufficiently well understood. As mentioned above, reductions as high as $50 \%$ can be achieved if improved stove technologies are adopted (efficiency increases from 20 to $35 \%$ for improved charcoal stoves). ${ }^{22}$ Some schools of thought argue that it may in fact be more advantageous to switch from charcoal or fuelwood to a conventional fossil fuel. Efficiencies of conversion for conventional gas stoves rarige up to $50 \%$, and although use of biomass fuels theo:etrally will result in "no net carbon emissions," this is a difficult argument to support in view of the extent of deforestation that has occurred from agricultural clearing and fue' pressures. Many, therefore, feel that fuel substitution from biomass (wood or charcoal) to liquified petroleum gas (LPG), bottled gas (usually propane), and/or coal, will have to occur in the future and that it may as well be

\footnotetext{
${ }^{22}$ Estimating efficiency inprovements of wood stoves is complicated by the moisture content of the fuel, the stove type (high or low thermal mass), and the user patterns. While wood stoves potentially can save more energy than charcoal stoves (taking into account the inetificiencies of conversion of the pyiolysis process), acceptance of these devices may in fact be more problematic.
} 
encouraged in the near term..$^{23}$ It has been argued that this conversion could have a doubled effect of reducing pressures on threatened forests as well as directly reducing emissions.

However, such a change can be very costly to the end user, as well as to the national economy; petroleum fuels require hard currency, and biomass does not. Ultimately, if sustainable biomass production is not achieved, this may be the most attractive alternative available to policy makers and national planners.

\footnotetext{
${ }^{23}$ Major lending institutions have recently taken this position in Niger and provide financial incentives to cncourage the conversion from biomass fuels in kerosene.
} 


\section{BIOLOGICAL CARBON ESTIMATES AND IMPACTS}

\subsection{INTRODUCTION}

\subsubsection{Objectives}

The estimation of biological carbon balances has two primary objectives: to develop predictions of Sub-Saharan Africa's carbon inventory and emissions between 1985 and 2001 assuming no change in the pattern of land-use trends and to determine the potential impact on carbon inventory and emissions from various land-use options to conserve carbon. ${ }^{24}$ The first half of this chapter outlines and explains the basic prediction methodology and presents model predictions of carbon inventory and emissions assuming continuation of current land use to the year 2001 (the base case). The second half of the chapter considers various landuse options for conserving carbon and discusses the results of two remote sensing activities. Model adaptions to predict carbon savings from various land-use options are explained, and option costs and carbon savings are presented.

\subsubsection{General Overvicw}

The principal focus of the biological carbon balance analysis was to formulate a regional-scale model capable of predicting the impact of various land-use options on carbon inventory and emissions. To accomplish this, the following model properties were essential:

- The model output must be geographically specific, at least to a subcouritry level in large countries.

- The model must incorporate, to the extent possible, environmental and social factors that control both carbon inventory and emissions as well as land-use dynamics. These factors include climate, soil quality, current vegetation type, human degradation, and agricultural systems (e.g., permanent or forest fallow).

- The modeling of land-use dynamics must be as geographically precise as possible but consistent over the entire region.

A supporting analysis was performed to improve knowledge of current land use and land-use change in central equatorial Africa through the use of satellite imagery. This region of Africa, with its vast forests, dominates the overall carbon inventory of the continent, yet it is the most poorly understood.

Remotely-sensed data were used in two distinct but complementary ways. Coarseresolution 1987-1988 NOAA AVHRR imagery was used to examine the current pattern of closed forest and to evaluate the accuracy of the continental vegetation map used as data input for the carbon inventory and emission model. Fine-resolution Landsat MSS and SPOT data from four Incations and two dates (early 1970s and late 1980s) were used to examine the

\footnotetext{
${ }^{24}$ For the biological carbon analysis, Sub-Saharan Africa included all African countries except those bordering the Mediterranean, Mauritania, South Africa, Gambia, Western Sahara, Lesotho, and Swaziland.
} 
pattern and rate of deforestation at the boundary of the closed forest and open woodland. Remote sensing analyses were performed in parallel with the modeling exercise and addressed only a portion of Sub-Saharan Africa. Therefore, the results of the analyses were not incorporated directly into the larger modeling effort. Rather, they were used to evaluate the reliability of the data driving the model and to examine sources of error in the modeling approach. The remainder of this chapter will discuss in the following order:

- approach and data sources for the base-case carbon inventory and emission model,

- base-case model predictions and comparison to other estimates of carbon emissions from Sub-Saharan Africa,

- modeling and cost analysis of three land-use management options (preservation of existing forest lands, agroforestry, and plantation forestry), and

- general results of remote sensing studies.

\subsection{MODELING BACKGROUND}

\subsubsection{Basc-Case Modeling Approach}

The approach chosen to model carbon inventory and emissions was shaped by a need to capture coarse-scale geographical variation in inventory and emissions; to link carbon inventory values to the factors controlling current and potential land use - current vegetation, climate, soil fertility, likelihood of human degradation, and agricultural systems; and to link carbon emissions with land-use change. In developing the model, the focus was on carbon emissions resulting from the conversion of forest land to agriculture. Carbon emission calculations took into account carbon losses from vegetation but not soil. Developing reliable values on carbon loss from the many soils that occur on the continent of Africa was beyond the scope of this project.

All carbon transfers (from the land to the atmosphere or vice versa) resulting from land-use change were assumed to accrue the year of land-use conversion; the real multiyear process of carbon storage due to plant growth or carbon release due to decomposition was not modeled. This simplification allowed comparison of land-use options with varying carbon conservation time scales. If the short-term temporal dynamics of carbon emissions or sequestering were predicted, it would be extremely difficult to compare the long-term, overall impacts to changes in atmospheric carbon due to deforestation, plantation establishment, agroforestry or any other land use.

For example, the carbon benefits from plantation establishment change yearly as the carbon balance shifts between the growth of the plantation of the current rotation and the decomposition of material harvested from the previous rotation. There will be years of sequestering carbon and years of releasing carbon. Thus, if one wants to know the net carbon benefit to the atmosphere of converting cropland into plantation, one needs to know the average amount of carbon stored on land as a consequence of plantation forestry - not the time sequence of that carbon storage. 


\subsubsection{Data Sources}

The primary data sources used in the model for calculating carbon emissions and inventory aie listed in Table 6 . Continental data bases were employed due to the scope and scale of the project. Use of local or subcontinental data bases was ruled out due to the inconsistencies in quality, coverage, and classifications of soil and vegetation that would have been encountered if a "patchwork" of data sources were constructed. There was neither sufficient time nor resources to create new data bases.

In contrast to the other data bases used, the FAO map of African vegetation is not yet in final form. The objective of the map is to depict actual vegetation and land use on the African continent. The FAO map differs from the most recent map of African vegetation The Vegetation of Africa, UNESCO (White 1983) - which is a floristic map depicting potential native vegetation rather than current land use. To illustrate the difference, the FAO map would depict the vegetation in Kansas as "cropland," while the White map would depict it as "prairie." Although the FAO map is the most up-to-date continental map of African vegetation, it still may not be accurate in all locations. The results of the remote sensing analysis suggested that the FAO map erred in defining the forest boundaries of the equatorial region of Africa (Chapter 4, Section 4.7.1). Of all the regions in Sub-Saharan Africa, one would expect errors in this region as the geography of this region is so poorly understood. The FAO forest boundaries in this region were in some cases developed from a 50-year-old map as this was the only one available. Thus, it is not surprising that satellite images might disagree with the mapped forest boundaries. The FAO map vegetation boundaries of most other regions of Sub-Saharan Africa were developed from much more recent maps and thus they are more likely to be accurate.

The FAO vegetation map defines 66 unique vegetation classes on the basis of 13 different vegetation types (see Table 7). Most of the vegetation classes are an amalgamation of two or three vegetation types. For example, there is a vegetation class that is described as a mixture of dense forest, tree savanna, and crops. Although this amalgamation feature posed some problems, it was also useful as it indicated where humans were most likely to have impacted the native vegetation. In the modeling approach it was assumed that native vegetation types (such as woodland-miombo) in classes which included either "cropland," "savanna fallow," or "forest fallow" vegetation types were likely to be heavily used by people and therefore to be "degraded" and contain less carbon. At times it was necessary to assume one of the vegetation types within a class was dominant. In such cases it was assumed that the first type listed in the class was the dominant type.

With the exception of the dense forest vegetation type, the upper range of Olson et al.'s (1985) ecosystem biomass values was used to define the maximum amount of carbon that 


\begin{tabular}{|c|c|}
\hline Data base & Use \\
\hline $\begin{array}{l}\text { FAO/Unesco soil } \\
\text { map of Africa } 1^{:}\end{array}$ & $\begin{array}{l}\text { Determination of potential site carbon inventory } \\
\text { Determination of potential site productivity }\end{array}$ \\
\hline $\begin{array}{l}\text { FAO climate } \\
\text { map of Africab }\end{array}$ & $\begin{array}{l}\text { Determination of potential site carbon inventory } \\
\text { Determination of potential site productivity } \\
\text { Determination of rainfall-vegetation type } \\
\text { relationship }\end{array}$ \\
\hline $\begin{array}{l}\text { FAO vegetation } \\
\text { map of Africa }\end{array}$ & $\begin{array}{l}\text { Determination of potential site carbon inventory } \\
\text { Determination of site degradation status } \\
\text { Determination of site land use } \\
\text { Determination of rainfall-vegetation type } \\
\text { relationship }\end{array}$ \\
\hline $\begin{array}{l}\text { FAO/UNEP Tropical } \\
\text { Forest Inventory }\end{array}$ & $\begin{array}{l}\text { Determination of deforestation rates } \\
\text { Determination of site land use }\end{array}$ \\
\hline $\begin{array}{l}\text { Carbon content } \\
\text { of vegetation }^{e}\end{array}$ & $\begin{array}{l}\text { Determination of maximum carbon of vegetation } \\
\text { type under ideal soil and rainfall }\end{array}$ \\
\hline $\begin{array}{l}\text { Political boundaries } \\
\text { of Africa }\end{array}$ & $\begin{array}{l}\text { Determination of country } \\
\text { boundary m.dp }\end{array}$ \\
\hline
\end{tabular}

${ }^{a}$ FAO-Unesco, 1977. Soil Map of the World, Vol. VI, Africa.

${ }^{b}$ FAO 1983. FAO Map of Mean Annual Rainfall and General Climate Zones for P/PET for Africa. Prepared by Todor Boyadgiev, Soil Resources Management and Conservation Service, FAO, Rome.

${ }^{\circ}$ Lavenu, F. 1987. Digitized Vegetation map of Africa - Descriptive memoir and map prepared for the Department of Forestry Resources, FAO, Rome.

${ }^{d}$ FAO/UNEP 1981. Forest resources of tropical Africa, 1981. Tropical Forest Resources Assessment Project, Vol.1 \& 2, Rome.

'Olson et al. 1985. Major world ecosystem complexes ranked by carbon in live vegetation: A database. Oak Ridge National Laboratory. Brown, Sandra and Ariel E. Lugo, 1984. Biomass of Tropical Forests: A New Estimate Based on Forest Volumes. Science, Vol. 223, 1290-1293.

'Rand-McNally, 1982. The New International Atlas, Chicago. FAO, 1983. FAO Maps and Statistical Data on Population and Crops by Administrative Units. FAO, Rome. 


\begin{tabular}{|c|c|c|}
\hline \multicolumn{3}{|c|}{$\begin{array}{c}\text { Table 7. Dominant vegetation types in the Sub-Saharan portion of the FAO/UNEP vegetation } \\
\text { map of Africa. The maximum carbon storage potential and "ideal" annual rainfall for these } \\
\text { types are also listed. ("Savanna fallow" vegetation type was also present but never dominant. } \\
\text { In addition, } 2 \text { of the } 13 \text { dominant } \\
\text { vegetation types were not present in the } \\
\text { Sub-Saharan portion of the map.) }\end{array}$} \\
\hline Vegetation type & $\begin{array}{c}\text { Maximum carbon } \\
\text { (tonne } \mathrm{C} / \mathrm{ha})\end{array}$ & $\begin{array}{l}\text { "Ideal" rainfall } \\
(\mathrm{mm} / \mathrm{yr})\end{array}$ \\
\hline Dense forest & 180 & 2500 \\
\hline Dense thicket & 54 & 125() \\
\hline Woodland/miombo & 81 & 1250 \\
\hline Discontinuous thicket & 45 & 1250 \\
\hline Tree savanna & 36 & 1750 \\
\hline Shrub savanna & 27 & 950 \\
\hline Grass savanna $^{\mathrm{c}}$ & 18 & 1750 \\
\hline Grass steppe/pseudosteppe & 4.5 & 325 \\
\hline Desert & 2.25 & 250 \\
\hline Forest fallow & $a$ & $\mathrm{a}$ \\
\hline Cropland & 5.0 & b \\
\hline
\end{tabular}

${ }^{2}$ Maximum carbon of forest fallow is a function of length of fallow cycle which is zone specific. As no vegetation class consisted solely of the forest fallow type, the ideal rainfall for forest fallow at any point is the ideal rainfall for the native vegetation type which also occurs at that point.

bIt was assumed that caibon storage of cropland is independent of rainfall.

'Grasslands in Africa frequently occur in areas of high rainfall. Such grasslands are believed to be due to edaphic and anthropogenic factors (White 1983). 
could be stored in an ecosystem with a given vegetation type. ${ }^{25}$ Olson et al.'s biomass values were global rather than Africa specific (i.e., they were derived from worldwide rather than just African data). Forest biomass data from Brown and Lugo (1984) suggest that the biomass of African forests is on the low end of the range for tropical forests. Therefore, Olson's median (400 tonnes of biomass/ha) rather than high value was used as the maximum ecosystem biomass value for the dense forest vegetation type. Olson et al.'s data were chosen because (1) the biomass values included all carbon other than soil carbon for a particular vegetation type (i.e., litter, roots, dead branches, and understory were included); (2) the data base encompassed almost all the vegetation lypes listed in the FAO vegetation map; and (3) the biomass values were generally in the median range reported by other researchers for specific vegetation types.

Data from the 1981 FAO/UNEP's Forest Resources of Tropical Africa Report were used to characterize land-use conversion and forest areas. These data on forest area and deforestation rates are country specific and based on country forcstry surveys and, in a few cases, on satellite imagery. They are the only regional data on tropical deforestation and forest area currently available. Within the FAO/UNEP report, projections are made for forest area and deforestation in 1985. These projections were used to characterize initial 1985 conditions in the model runs.

\subsubsection{Modeling with Geographical Specificity}

To capture the vast geographical differences in inventory and emissions over SubSaharan Africa, carbon emissions and inventory were modeled at approximately 9000 regularly spaced point locations across the continent (see Fig. 6). To associate the point carbon emissions and inventory values with a geographic area more environmentally significant than "country," a map was created to divide most African countries into two or three zones on the basis of likely within-country variations in overall carbon inventory (see Fig. 7). For example, Zaire was divided into two zones - a zone for the closed forest and a zone for the woodland area bounding the closed forest. Smaller countries without significant vegetational heterogeneity were treated as a single zonc. Thus each point had not only a country identity but also a zonal identity. Zones became the smallest geographic unit with which points were associated.

To convert these point values of carbon inventory or emissions, which had units of tonnes of carbon per hectare or tonnes of carbon per hectare per year, to zonal estimates (tonnes of carbon per zone or tonnes of carbon per zone per year), the point values within a zone of a country were averaged and the resulting value multiplied by zonal area. Country and regional emissions and inventories were calculated by summing the zonal values within a country or the country values within the region. This point-based approach can be likened to taking many point samples of soil in a field to characterize the overall fertility of the field.

\footnotetext{
${ }^{25}$ Biomass was assumed to be $45 \%$ carbon; thus biomass values were converted to carbon values using a multiplier of 0.45 (Houghton et al. 1983).
} 


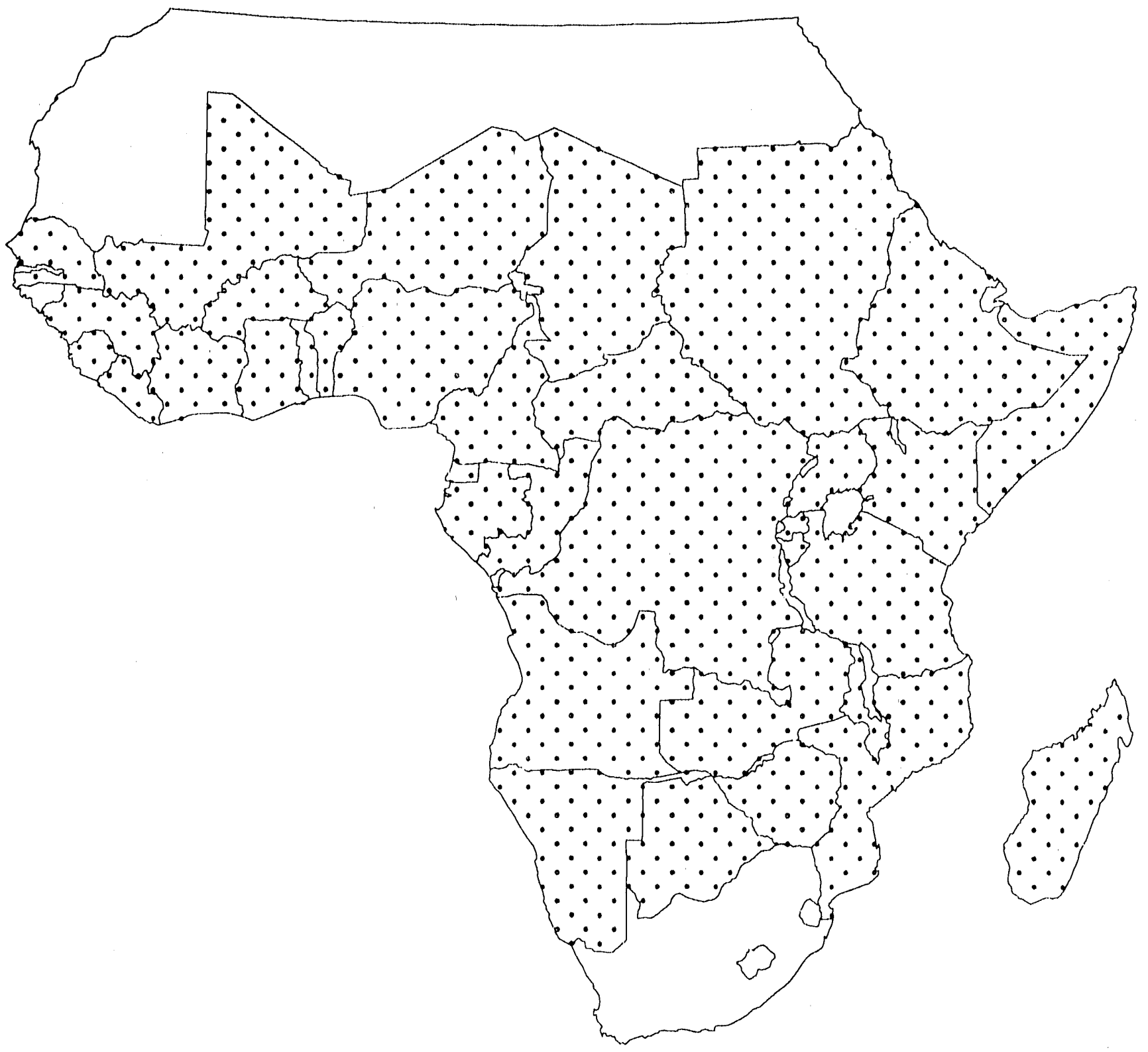

Fig. 6. Illustration of point sampling strategy used in characterizing geographic variability in carbon emissions and inventory in Sub-Saharan Africa. 


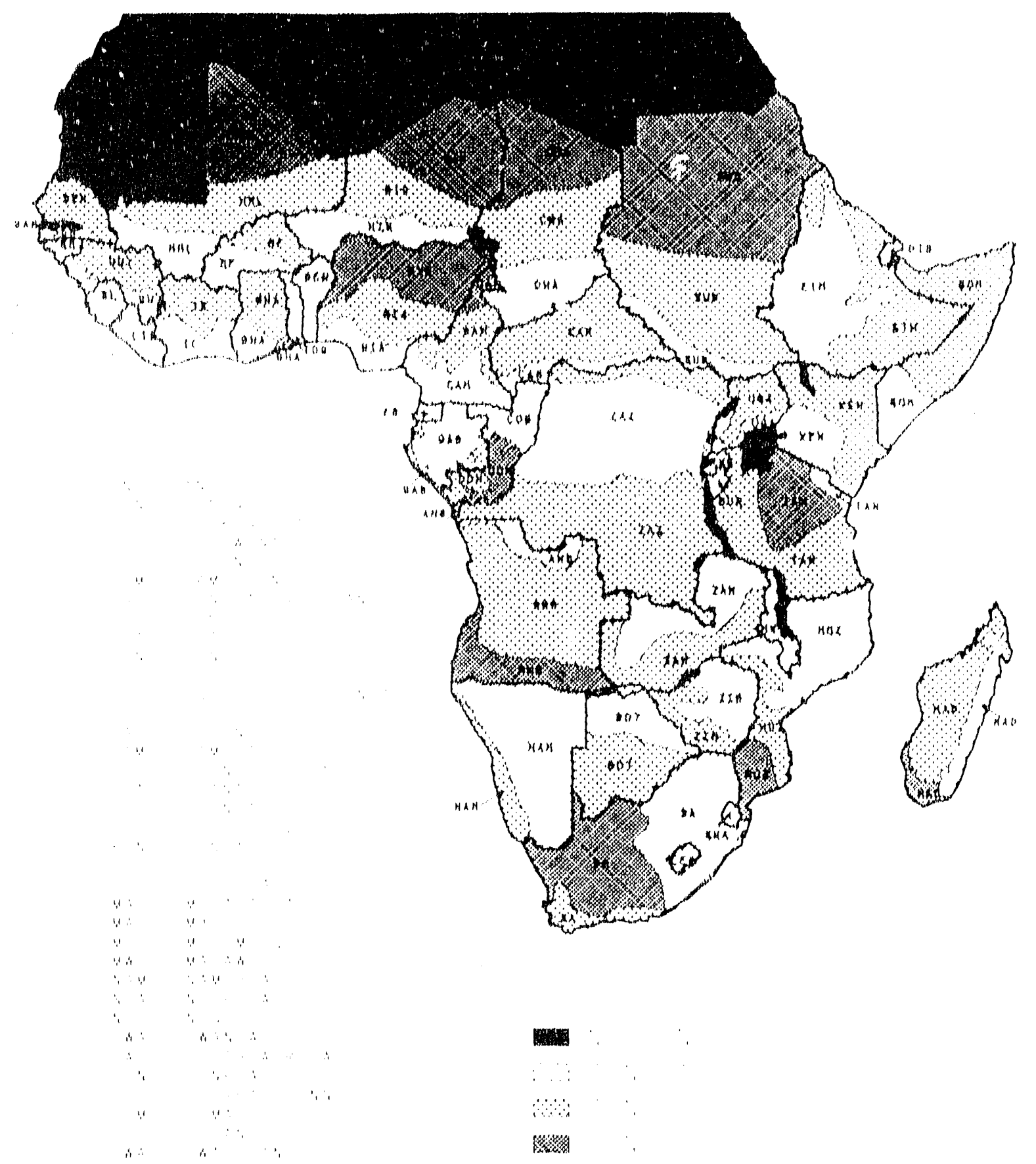

Fig. 7. Country zone map. Zones differentiate within country variations in carbon inventory. Zone 1 has the greatest carbon inventory per unit area and zone 3 the loast. Zones are not comparable among countries. For example, Zone 1 of Zaire has much more carbon than Zone 1 of Chad. 
Data needed for modeling carbon inventory and cmissions - soil fertility, annual rainfall, current vegetation class, zonc, and country - were extracted from the FAO/UNEP/Unesco maps and the zone map using a geographic information system (GIS) (sec Fig. 8). The GIS was used in conjunction with digital versions of the maps to systematically extract the map values for soil unit, average rainlall, etc., at $0.4^{\circ}$ intervals in latitude and longitude. The extractel values were used to ereate a $9(x)$-reecord data base, cach record of which provides soil fertillty, ${ }^{26}$ annual rainfall, vegetation class, zone, and country occurring at specific point locations. This data base was then processed using SASprograms, outside of the GIS, to model carbon inventory and emission dynamics at each point and to aggregate the point predictions into zone, country, and region estimates. Figure 9 outlines and explains the major steps involved in the methodology for predicting carbon inventory and emissions; Fig. 10 outlines the general flow of the carbon inventory and emission model. The following text describes the major eomponents of the model - land-use modeling, modeling of carbon inventory, and calculation of carbon emissions.

\subsection{COMPONEN'IS OF 'THE CARBON INVEN'TORY AND EMISSION MODEL}

\subsubsection{Modeling Iand-Use Dynamics}

All land was assigned to one of three land-use calegories - "forest," "forest fallow," and "other." "Forest" included elosed and open forest. ${ }^{27}$ "Forest lallow" was land that was in some form of forest-fallow agriculture; that is, the land was cropped 1 to 3 year then fallow for 3 to 20 year, then cropped again. "Other" included both permanent agriculture and native vegetation that was not forest land -- such as grassland. The pereentage of land in three landuse classes was tracked yearly belween 1985 and 2001 at each point location. Changes in the amount of land in each elass at each point were a function of the relative rate of deforestation. ${ }^{28}$ Each year the forest land was redued according to the relative deforestation rate, and the amounts of "forest fallow" and "other" land increased aceordingly. The land-use dynamics involved are illustrated in Fig. 11. Total land area in "forest," "forest fallow," or "other" in any zone wass determined by averaging the point values within a zone within a country and multiplying by the area within the zone.

\footnotetext{
${ }^{26}$ Soil unit type values extracted from the soil map were translated into soil fertility class values (high $=1$, medium $=2$, low $=3$ ) on the basis of background information on soil fertility associated with soil units (FAO-UNESCO 1977).

${ }^{27}$ The terms "closed" and "open" refer to the canopy structure of a forest. "Closed" forest has a sufficiently dense canopy that little light penetrates to the forest floor and there is no grass in the understory (crown cover is greater than 50\%). "Open" forest in contrast has an open canopy which allows enough light to penetrate to the ground to support a grass understory (crown cover is greater than $10 \%$ but less than $50 \%$ ).

28" Relative rate of deforestation" is the percentage of the forest which is deforested cach year; it has units of pereent per year. "Absolute rate of deforestation" is the actual area deforested each year; it has units of hectares per year.
} 







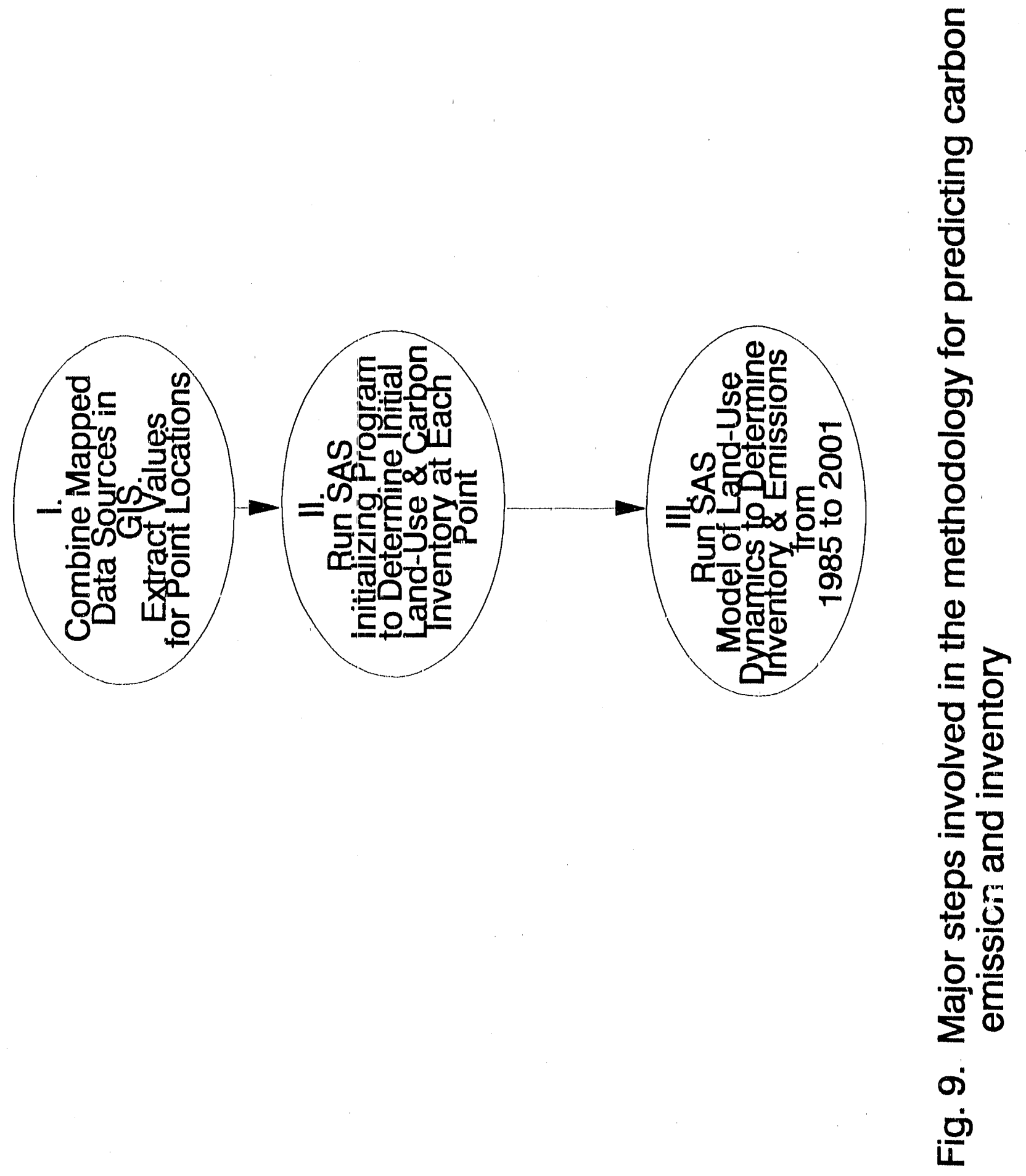




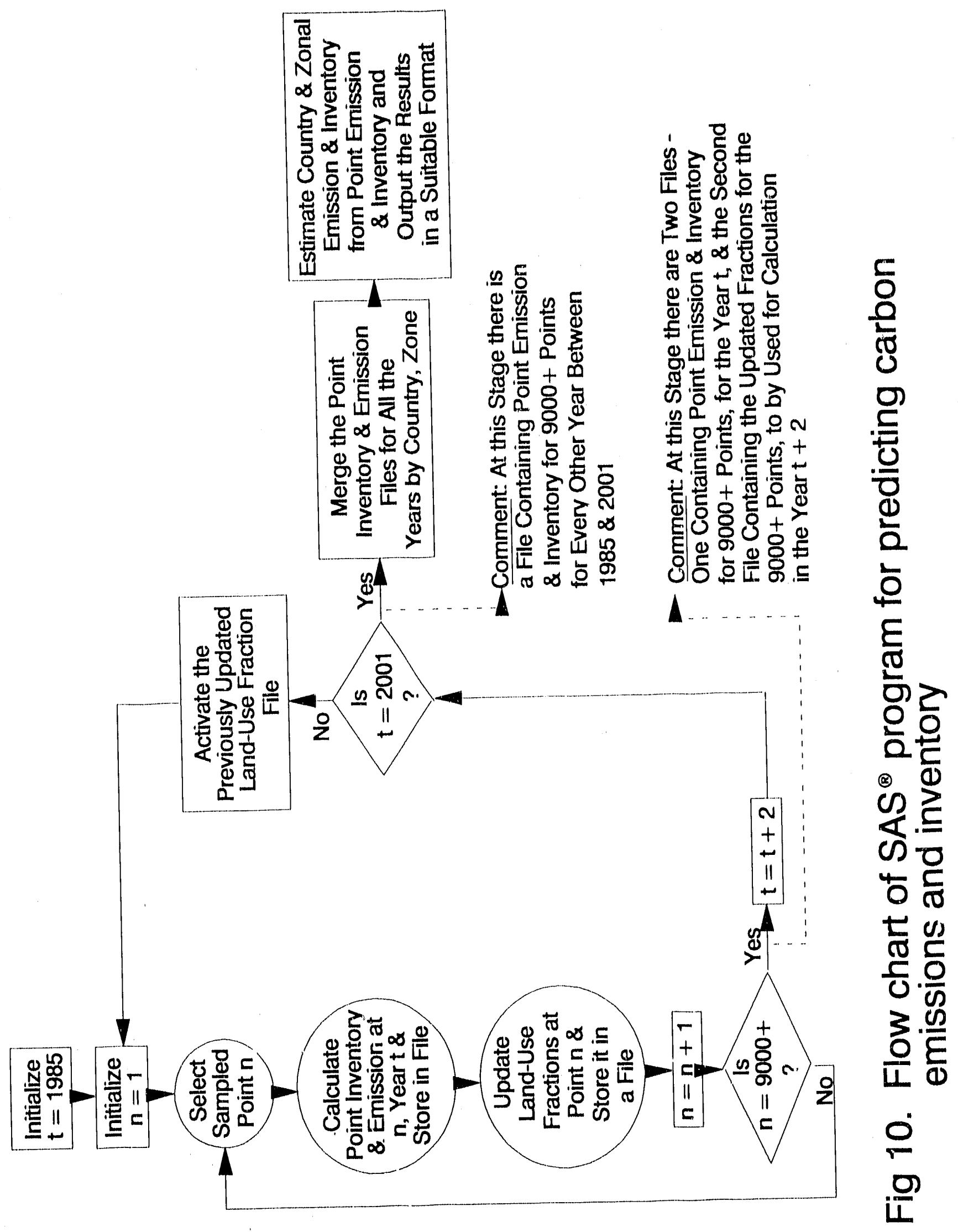



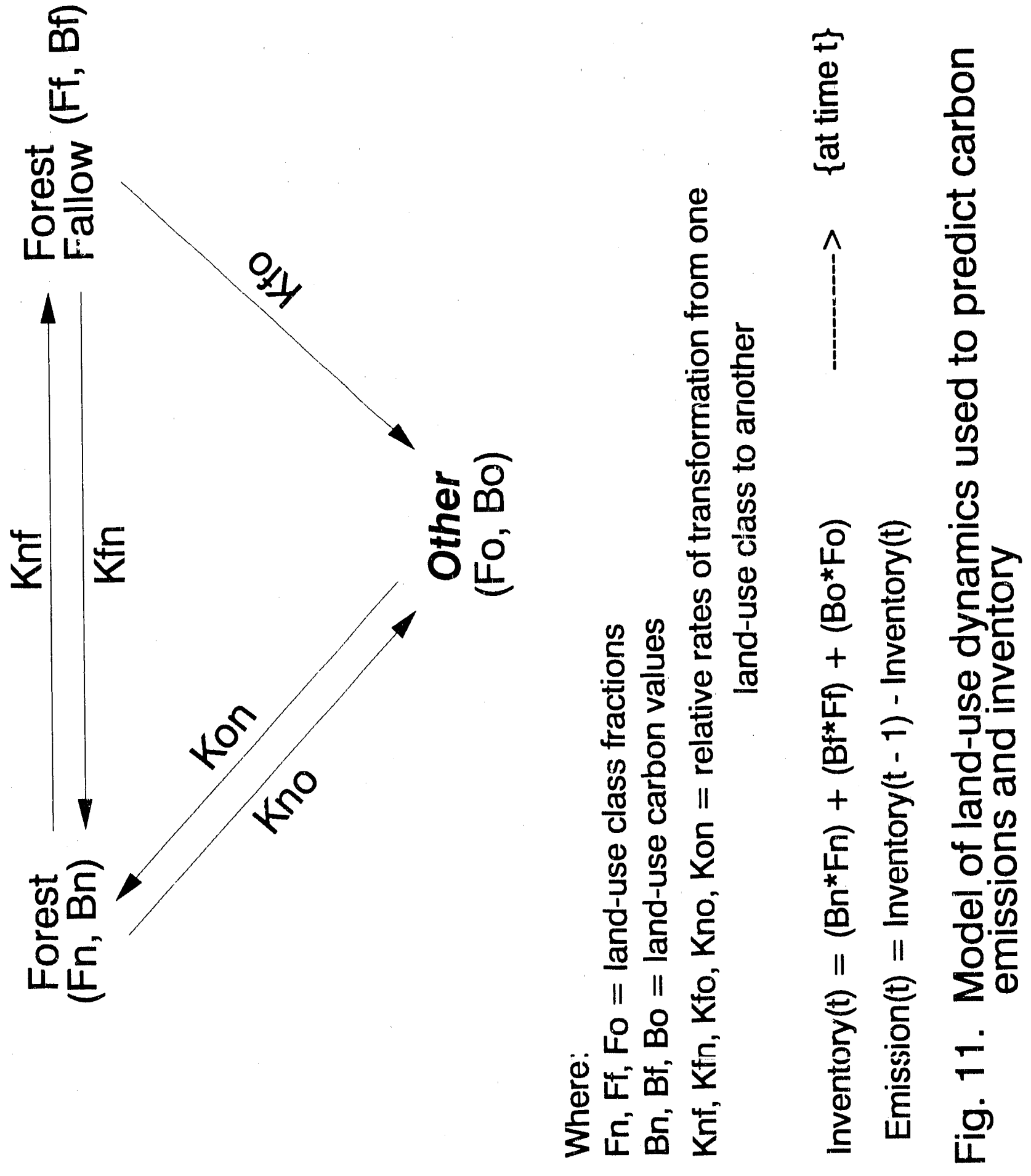
Percentage of land area in each country that was in "forest" or "forest-fallow" land use in 1985 (at the beginning of the model run) was calculated using FAO/UNEP's Forest Resources of Tropical Africa report (FAO/UNEP 1981) values on land area in forest or forest fallow and country values for total land area. The estimate of percent land area in "forest" included FAO/UNEP's "closed" and "open" and "productive" and "unproductive" forest classes but did not include FAO/UNEP's "shrub" class. The estimate of percent land in forest fallow included FAO/UNEP's "closed" and "open" forest fallow. The "forest-fallow" land-use designation encompasses that land in the crop portion of the forest-fallow crop cycle. This is in agreement with FAO's definition of forest-fallow land. ${ }^{29}$ As noted before, all land that was neither in forest nor in forest fallow was defined as "other" land.

Relative rates of annual deforestation (the permanent conversion of forest land to forest-fallow agriculture or to permanent agriculture) were developed using country-specific estimates of the amount of land deforested in 1985 and the total amount of forested land in 1985 (FAO/UNEP 1981). The relative rate of overall deforestation was calculated as the ratio of the acreage deforested in 1985 to the acreage in forest in 1985. The FAO/UNEP values for deforested land do not include forest land which has been harvested but maintained as forest land. Thus the rate is for land-use conversion and not for the area harvested. The rate of deforestation that was due to conversion to forest-fallow agriculture rather than permanent agriculture was assumed to be $50 \%$ of the overall rate (Houghton et al. 1983) unless there was country-specific information in FAO/UNEP's report to indicate otherwise. Within a country, the relative rates of deforestation were assumed to be the same at all points and for all forest types.

In the base-case model, the relative rate of deforestation is assumed to be constant over time. ${ }^{30}$ It is also assumed that there is no conversion of (1) forest-fallow land use to permanent agriculture land use, (2) agricultural land to forest or forest fallow land, or (3) forest-fallow land to forest: that is, these conversion rates are assumed equal to zero in the base case. This is clearly not the case in the real world, but continentally consistent data are unavailable for deriving rates for these conversions (Detwiler and Hall 1988). However, the model is constructed such that if values for these rates were available, they could readily be incorporated. Likewise, when deforestation rates from the 1990 FAO/UNEP's Tropical Forest Resources Assessment Project become available, these may also be incorporated into the model.

At the start of a model run, a certain fraction of the land at each point is assigned to each land-use class. These fractional values are assigned according to the point's vegetation class, the country in which the point falls, and the percent "forest," percent "forest-fallow," and percent "other" land within that country in 1985 (as given by the FAO/UNEP Tropical Forest Resources of Tropical Africa). The point fractions are assigned such that the average point

\footnotetext{
${ }^{29}$ K. D. Siıgh, FAO, Rome, personal communication to Robin L. Graham, September 1989. carbon.

${ }^{30}$ The relative deforestation raic was altcred when examining land options for conserving
} 
fraction for a land-use class within a country corresponds to the FAO/UNEP's country-level value for that class in 1985 .

This approach of using land-use fractions was developed to reconcile the FAO/UNEP's Forest Resources of Tropical Africa's estimates of forest area with forest area indicated on FAO's vegetation map. The model is dependent on the former data base for deforestation rates and on the latter for calculating initial carbon inventory. In a given country, the amount of land designated on the FAO vegetation map to be forest or some blend of forest and some other vegetation type was not necessarily the same amount as reported by FAO/UNEP's Forest Resources of Tropical Africa. For example, FAO/UNEP's Forest Resources of Tropical Africa reported that $68 \%$ of the land in Cameroon was either in forest or forest fallow while only $54 \%$ of the Cameroon points sampled off the FAO vegetation map had vegetation class values that indicated the presence of some forest or forest fallow agriculture. In other countries the reverse was true. Thus development of the algorithms for assignation of initial land-use fractions to points with a specific vegetation class required considerable judgment and interpretation. Individual algorithms for assigning landuse fractions had to be developed for each vegetation class that occurred in each country.

Annual changes in land use were modeled at each point. Each year, a pereentage of the forest land (the overall relative deforestation rate) was converted to forest fallow land or permanent agriculture. The fraction of land in forest fallow or permanent agriculture was then updated to reflect this conversion (Fig. 10). Thus points that were high in forest lost more forest than points that were low. However, as noted before the relative rate of deforestation was uniform within a country. Deforestation is unlikely to be uniform within a country. Areas of high population density most likely have higher rates of deforestation than do areas of low population density. The existing deforestation statistics however, are countrylevel statistics thus there is no way to account for within country variation in relative deforestation rates. This problem may be solved in the future as the upcoming 1990 Tropical Forest Resource Assessment by FAO/UNEP will develop region-specific algorithms relating deforestation to population density. ${ }^{31}$

\subsubsection{Modcling Carbon Inventory}

Carbon inventory was calculated for every other year from 1985 to 2001 for each zone within each country. At the beginning of a model run, the carbon storage value of each landuse class at each point location was determined. The carbon storage values for each land-use class represent the amount of carbon (excluding soil, animal, and fungal carbon but including carbon in belowground vegetation and dead vegetation) that would be found on one hectare in that land-use class at that location. Thereafter, biannual carbon inventory calculations were a two stage process - (1) calculation of each point carbon inventory from the weighted (by land-use fraction) carbon storage values of the three land-use classes (Fig. 12) and (2) calculation of carbon inventory for each of the zones (Fig. 10). The following teat elaborates on the carbon inventory model and calculations.

\footnotetext{
${ }^{31}$ K.D. Singh, director of the 1990 Tropical Forest Resource Assessment Project, personal communication to R.L. Graham.
} 


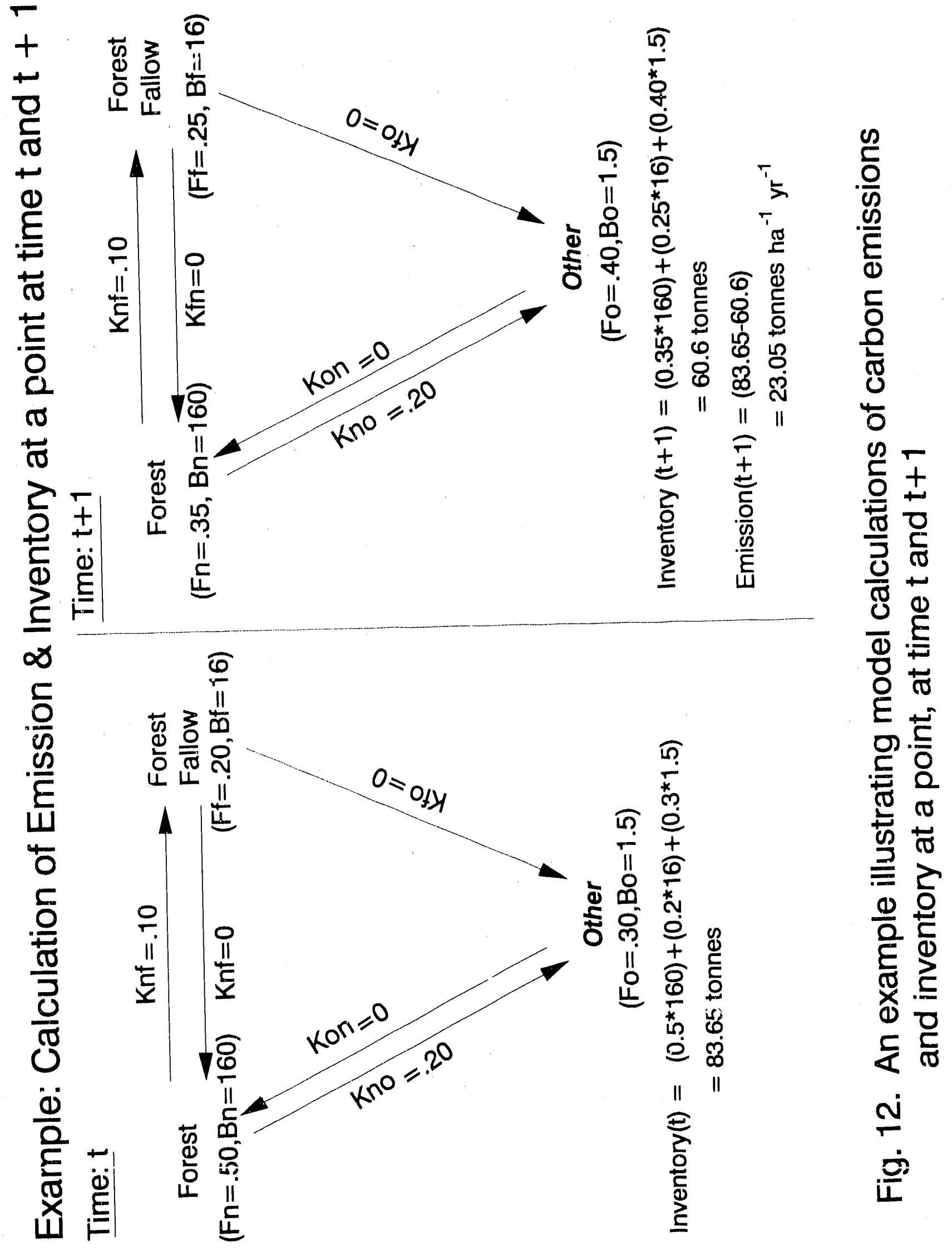


Modeling carbon storage values for each of the three land-use classes. The carbon storage values of each land-use class at each point were determined in a two-step process. First, the amount of carbon that would be stored in native, undegraded ecosystems, forestfallow agriculture ecosystems, or permanent agriculture ecosystems at that point was determined. These values along with information on the land-use classes occurring at that point in 1985 and the likelihood of the native vegetation having been degraded were then used to assign carbon storage values for the land-use classes.

A different algorithm for predicting carbon storage was used for each ecosystem type. The carbon storage of a native undisturbed ecosystem at a particular point was predicted on the basis of dominant vegetation type, annual rainfall, and soil fertility class. Each vegetation type was assigned a maximum carbon storage value that would occur under situations of high soil fertility and optimal rainfall. Table 7 lists the maximum carbon storage and optimal annual rainfall associated with each vegetation type. As noted before, the maximum carbon storage value comes from Olson et al. (1985). The optimal rainfall was determined using the rainfall values associated with each of the vegetation types. ${ }^{32}$ Optimal rainfall was defined as that amount of rain below which 95\% of the vegetation type is found growing. To adjust the carbon storage value of a native undegraded ecosystem to the local point conditions, the maximum carbon storage potential of the dominant vegetation type was reduced if the soil fertility or rainfall at that point were less than the "optimal." The algorithm for making those reductions is as follows:

$$
\mathrm{BN}_{z}=\operatorname{BNMax}_{\mathrm{q}} *\left(\mathrm{RAIN}_{z} / \operatorname{RAINMax}_{\mathrm{q}}\right) *\left(2 * \mathrm{SOIL}_{z} /\left(3 * \mathrm{SOIL}_{\mathrm{z}}-1\right)\right)
$$

where:

$\mathrm{BN}_{\mathrm{z}}=$ actual carbon storage in native vegetation at point,

$\mathrm{BNMax}_{4}=$ the maximum carbon storage associated with vegetation type Q,

RAINMax $_{\mathrm{q}}=$ the optimal rainfall associated with vegetation type Q,

SOIL $_{z}=$ soil fertility class at point ("1" = high, "2" = moderate, "3" = low),

RAIN $_{z}=$ annual rainfall at point (If RAIN,$>$ RAINMax $_{4}$, then

RAIN $_{z}=$ RAINMAX $_{4}$,

$z$ = point location,

$q=$ vegetation type at point.

This relationship is based on observations of carbon storage relative to soil fertility in temperate forest plantations as well as data suggesting a lincar relationship between rainfall and tropical ecosystem biomass (Houghton et al. 1985b, Lugo et al. 1988). A more complex algorithm could easily be substituted into the model if a more thorough analysis of the relationship between tropical ecosystem biomass, soils, and rainfall indicated a more complex algorithm was warranted.

The carbon storage of a forest fallow agriculture ecosystem at a site was predicted on the basis of potential carbon of a native ecosystem at that site and the numbers of crop and

\footnotetext{
${ }^{32}$ The relationship between annual rainfall and vegetation type at a point was developed using the database created by sampling the rainfall and vegetation maps.
} 
fallow years in a single crop fallow cycle. The crop and fallow years are country and zone specific and are summarized in Table 8 . The forest-fallow carbon value represents the average carbon that would be stored on site over the entire fallow-crop cycle. The algorithm for computing carbon storage of forest fallow agriculture at a site is as follows:

$$
\begin{gathered}
\text { BFAVG }_{z}=\left\{\left(\left(\left(\text { BN }_{z}^{*} \text { FALLYR }_{z} / 50\right) / 2\right)^{*} \text { FALLYR }_{z}\right)+\left(\text { CROPYR }_{z}^{*}{ }^{*} \text { CROP }\right)\right\} / \\
\left(\text { CROPYR }_{z}+\text { FALLYR }_{z}\right)
\end{gathered}
$$

where:

$\mathrm{BFAVG}_{\mathrm{z}}=$ average carbon storage over an entire fallow rotation cycle, $\mathrm{BN}_{2}=$ actual carbon storage in native vegetation at point, CROPYR $_{\mathrm{z}}=$ number of years in crop portion of cycle, FALLYR $=$ number of years in fallow portion of cycle,.

$\mathrm{CROP}=$ average biomass storage during the crop phase of the cycle.

$\mathrm{z}=$ point location. (crop $=5.0$ tonnes $\mathrm{C} / \mathrm{ha}$ ),

The algorithm assumes that carbon storage in biomass increases linearly with each year in the fallow portion of the cycle and that it would take 50 fallow years to achieve the carbon storage present in native vegetation at that site. A linear increase in carbon storage during the forest regrowth phase of the fallow forest agriculture system is a first approximation used by others in modeling carbon storage in fallow forest agriculture (Houghton et al. 1985a). Fifty years was selected as a typical interval for forest recovery (Houghton et al. 1985a). The data are quite limited on this topic as it is difficult to age tropical forests. The carbon storage of permanent agriculture was assumed to be 5.0 tonnes/ha regardless of site attributes (Houghton et al. 1985a).

If the vegetation class (as opposed to land-use class or vegetation type) at the point was one that included "cropland," "forest fallow," or "savanna fallow," then it was assumed that the native vegetation at that point would be degraded and its carbon-storage biomass was reduced by $35 \%$.

Land-use carbon values were derived from the three ecosystem-type carbon-storage values according to the rules outlined in Table 9. The resulting land-use carbon values ranged considerably. The area-weighted average forest carbon land use value for the entire region was 65.7 tonnes/ha. The low average reflects the dry woodlands with an open canopy that characterize much of Africa's forested area. The value lies halfway between the estimates of carbon storage of closed forest (90 tonnes/ha) and open forests (30 tonnes/ha) used in the most recent estimation of carbon loss from global tropical deforestation (Detwiler and Hall 1988). The average fallow-forest land-use carbon value was 5.9 tonnes $\mathrm{C} / \mathrm{ha}$. This value is lower than the fallow forest carbon storage values used in other estimates of carbon loss from tropical deforestation (Houghton et al. 1987). Nonforest land-use carbon values averaged 8.05 tonnes/ha on sites initially classed as $100 \%$ nonforest land use. Once the carbon valıes for each land-use class were determined at the beginning of the model run (1985), they did not change and were used in all subsequent yearly calculations of carbon inventory. 


\begin{tabular}{|c|c|c|c|}
\hline Country & Zone & Crop year & Fallow year \\
\hline Angola & $1,2,3$ & 2 & 20 \\
\hline Benin & 1 & 2 & 6 \\
\hline Botswana & 1,2 & 2 & 10 \\
\hline Burkina Faso & $\begin{array}{l}1 \\
2 \\
\end{array}$ & $\begin{array}{l}2 \\
2 \\
\end{array}$ & $\begin{array}{r}10 \\
6 \\
\end{array}$ \\
\hline Burundi & 1 & 3 & 3 \\
\hline Cameroon & $\begin{array}{c}1 \\
2,3 \\
\end{array}$ & $\begin{array}{l}2 \\
2\end{array}$ & $\begin{array}{r}6 \\
10\end{array}$ \\
\hline Central African Rep. & 1,2 & 2 & 10 \\
\hline Chad & $\begin{array}{l}1 \\
2 \\
3\end{array}$ & $\begin{array}{l}2 \\
2 \\
2 \\
\end{array}$ & $\begin{array}{r}10 \\
6 \\
20\end{array}$ \\
\hline Congo & $1,2,3$ & 2 & 10 \\
\hline Eq. Guinca & 1 & 2 & 10) \\
\hline Ethiopia & $\begin{array}{l}1 \\
2\end{array}$ & $\begin{array}{l}2 \\
2 \\
\end{array}$ & $\begin{array}{r}6 \\
10 \\
\end{array}$ \\
\hline Gabon & 1,2 & 2 & 10) \\
\hline Gambia & 1 & 3 & 3 \\
\hline Ghana & $\begin{array}{l}1 \\
2 \\
3 \\
\end{array}$ & $\begin{array}{l}2 \\
2 \\
1 \\
\end{array}$ & $\begin{array}{r}6 \\
10 \\
0 \\
\end{array}$ \\
\hline Guinca & $\begin{array}{l}1 \\
2\end{array}$ & $\begin{array}{l}2 \\
2\end{array}$ & $\begin{array}{r}6 \\
10\end{array}$ \\
\hline Ivory Coast & $\begin{array}{l}1 \\
2 \\
\end{array}$ & $\begin{array}{l}2 \\
2 \\
\end{array}$ & $\begin{array}{r}6 \\
10 \\
\end{array}$ \\
\hline Kenya & 1,2 & 2 & 6 \\
\hline Liberia & 1 & 2 & 6 \\
\hline Madagascar & $\begin{array}{c}1 \\
2,3 \\
\end{array}$ & $\begin{array}{l}2 \\
2 \\
\end{array}$ & $\begin{array}{r}6 \\
10 \\
\end{array}$ \\
\hline Malawi & 1 & 3 & 3 \\
\hline Mali & $\begin{array}{l}1 \\
2 \\
3 \\
\end{array}$ & $\begin{array}{l}2 \\
2 \\
2 \\
\end{array}$ & $\begin{array}{r}10 \\
6 \\
20\end{array}$ \\
\hline Mozambique & $1,2,3$ & 2 & 6 \\
\hline
\end{tabular}




\begin{tabular}{|c|c|c|c|}
\hline Country & Zone & Crop year & Fallow year \\
\hline Namibia & 1,2 & 2 & 20 \\
\hline Niger & $\begin{array}{l}1 \\
2 \\
3 \\
\end{array}$ & $\begin{array}{l}2 \\
2 \\
2 \\
\end{array}$ & $\begin{array}{r}10 \\
6 \\
20 \\
\end{array}$ \\
\hline Nigeria & $\begin{array}{l}1 \\
2 \\
3\end{array}$ & $\begin{array}{l}3 \\
2 \\
2\end{array}$ & $\begin{array}{r}3 \\
6 \\
10\end{array}$ \\
\hline Rwanda & 1 & 3 & 3 \\
\hline Senegal & $\begin{array}{l}1 \\
2\end{array}$ & $\begin{array}{c}2 \\
2\end{array}$ & $\begin{array}{r}10 \\
6 \\
\end{array}$ \\
\hline Sierra Leone & 1 & 2 & 6 \\
\hline Somalia & $\begin{array}{l}1 \\
2 \\
\end{array}$ & $\begin{array}{l}2 \\
2 \\
\end{array}$ & $\begin{array}{l}10 \\
20 \\
\end{array}$ \\
\hline Sudan & $\begin{array}{l}1 \\
2 \\
3 \\
\end{array}$ & $\begin{array}{c}2 \\
2 \\
2 \\
\end{array}$ & $\begin{array}{r}10 \\
6 \\
10 \\
\end{array}$ \\
\hline Tanzania & $1,2,3$ & 2 & 6 \\
\hline Togo & 1 & 2 & 6 \\
\hline Uganda & $\begin{array}{l}1 \\
2 \\
\end{array}$ & $\begin{array}{c}3 \\
2 \\
\end{array}$ & $\begin{array}{l}3 \\
6 \\
\end{array}$ \\
\hline Zaire & 1,2 & 2 & 10 \\
\hline Zambia & 1,2 & 2 & 10 \\
\hline Zimbabwe & 1,2 & 2 & 6 \\
\hline
\end{tabular}

Source: Derived in part from FAO (1984), Changes in Shifting Cultivation in Africa. 


\begin{tabular}{|} 
Table 9. Rules used to assign carbon values to land-use classes at cach \\
point on the basis of initial (1985) point land use
\end{tabular}

${ }^{a}$ Although no forest fallow is present initially in 1985, forest fallow land use will occur in subsequent years as a consequence of deforestation of the original forest. Thus a forest fallow carbon value is assigned to that site for application in future years. 
Calculating point carton inventory. To calculate the carbon inventory at any point at any year, the carbon value of each land use class was weighted by the fraction of land in that land-use class at that year, and the weighted carbon values were summed. Table 10 gives an example of such a calculation for a typical point in a forested region of Zaire.

Calculating zonal and country values for cartoon inventory. To determine the zonal carbon inventory value, the overall average carbon inventory for all points within a zone was calculated. This value was then multiplied by the number of hectares within that zone. In summary, zonal carbon inventories were a function of the land use in the zone and the carbon values associated with those land-use classes. The carbon values in turn were a function of the soils, climate, and vegetation classes found within the zone.

\subsubsection{Modcling Annual Carbon Emissions}

Calculation of carbon emissions was straightforward. Annual emissions were simply the differenee between carbon inventories one year and the next (Fig. 12). As noted earlier, this method of calculation of carbon emissions implicitly assumes that loss or gain of any carbon due to land-use conversion occurs the year of the conversion. In the base-case model, yearly carbon inventories differed only as a consequenee of annual changes in the relative amount of land in each of the land-use classes. The carbon values associated with each of the land-use classes at each point did not change. Furthermore, land-use change was solely a function of country-specific relative deforestation rates, which also did not change over the 1985-2001 time interval. Of course, because relative rather than absolute deforestation rates were used, the emissions rates were not constant over time area, nor were inventories.

\subsection{BASE-CASE MODELING RESULTS}

Three countries (Ivory Coast, Zaire, and Nigeria) are the most significant contributors of carbon emissions in 1985, contributing 48.9, 33.4, and 24.4 million tonnes, respectively (Table 11). Ivory Coast's and Nigeria's initial high values are not sustained; by 2001 their values drop to 15.3 and 14.7 million tonnes C/yr, respectively (Fig. 13). This is because their relative rate of deforestation is so high that it rapidly depletes the forest inventory (from 870 ) million tonnes in 1985 to 390 million tonnes in 2001 for Ivory Coast and from 1730 million tonnes to 1420 million tonnes for Nigeria over the same period). Consequently, there is much less forest to deforest in later years. If the model had used absolute rates of deforestation rather than relative rates, the drop in carbon inventory would have been much more precipitous. Zaire differs in that it has a fairly low relative rate of deforestation but a very large inventory; consequently, its emissions drop very little between 1985 and 2001 (from 33.4 to 32.2 million tonnes). Thus, Zaire takes on a more important role in regional carbon 


\begin{tabular}{|c|c|c|c|}
\hline $\begin{array}{l}\text { Land-use } \\
\text { class }\end{array}$ & $\begin{array}{l}\text { Land-use } \\
\text { carbon value }\end{array}$ & $\begin{array}{c}\text { Land-use } \\
\text { fraction in } \\
1991\end{array}$ & $\begin{array}{l}\text { Weighted carbon } \\
\text { valuc in } 1991\end{array}$ \\
\hline Forest & 144.0 tonnes $\mathrm{C} / \mathrm{ha}$ & 0.80 & 115.2 tonnes $\mathrm{C}$ \\
\hline Forest fallow & 15.2 tonnes $\mathrm{C} / \mathrm{ha}$ & 0.15 & 2.28 tonnes $\mathrm{C}$ \\
\hline Other & 3 tonnes $\mathrm{C} /$ ha & 0.05 & 0.15 tonnes $\mathrm{C}$ \\
\hline $\begin{array}{l}\text { Carbon inventory in } \\
1991 \text { at point }\end{array}$ & & & 82.85 tonnes $\mathrm{C} / \mathrm{ha}$ \\
\hline
\end{tabular}




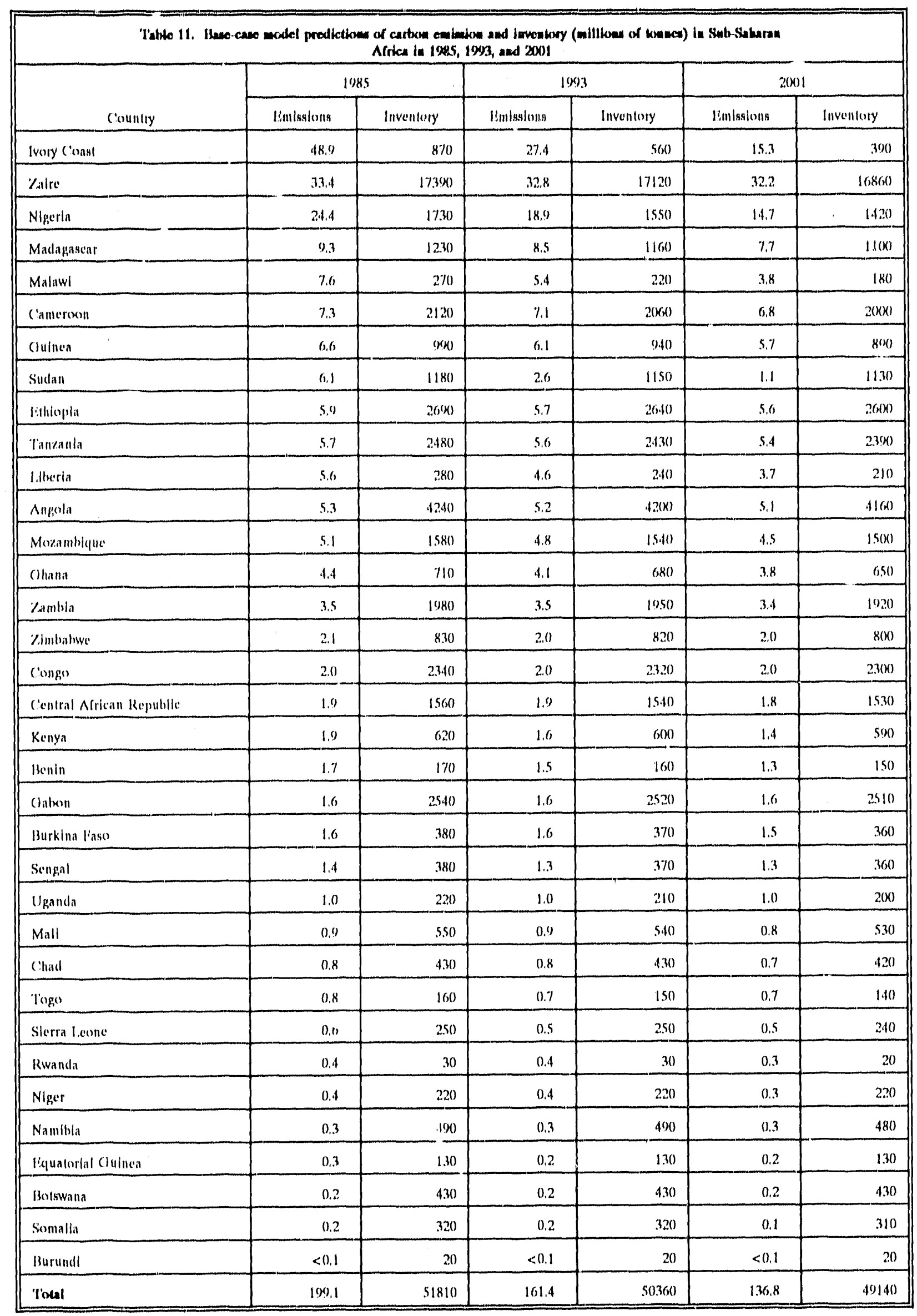




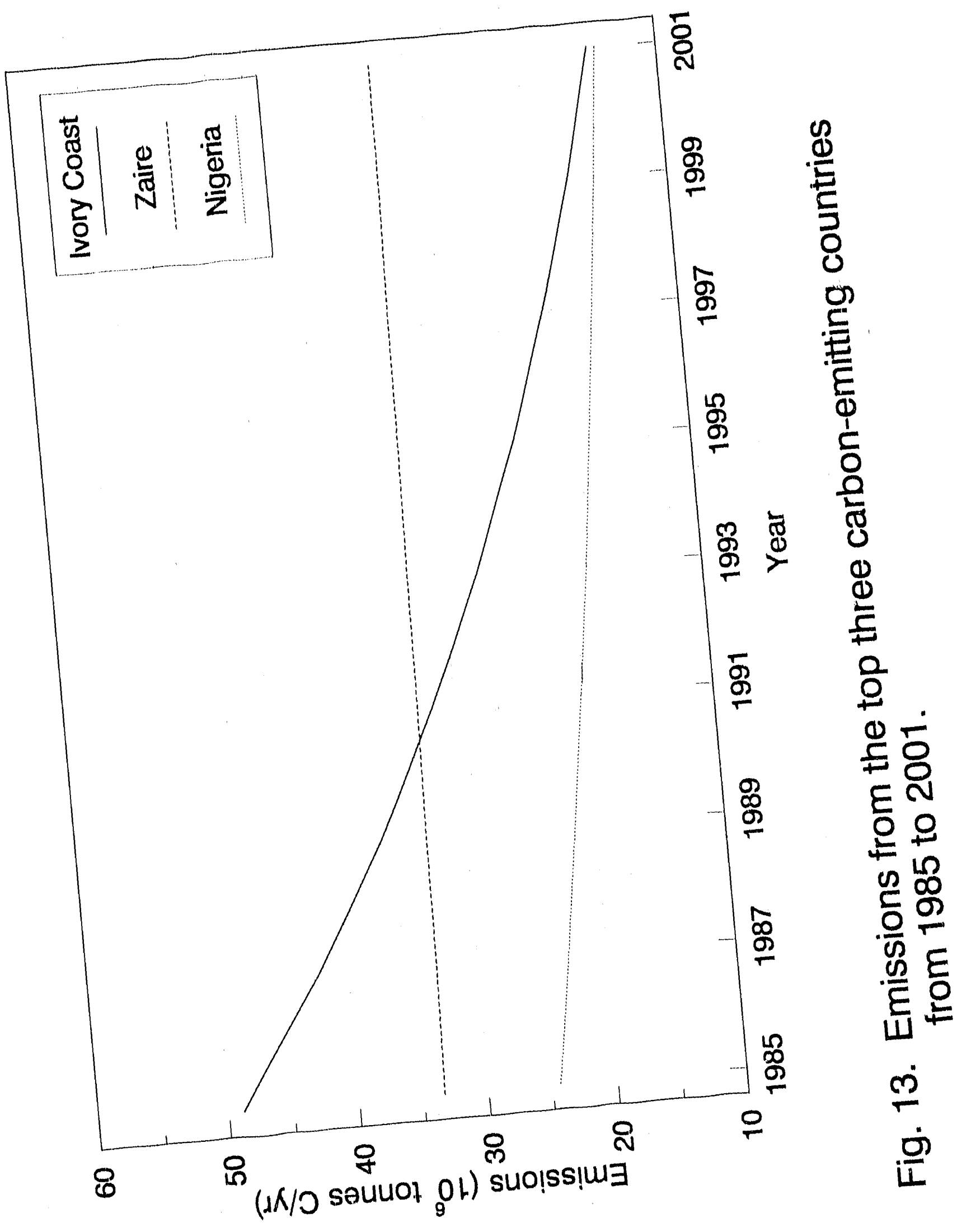


emissions over the years. A compantson of the average carbon emissions from 1991 to 2001 , ranked by the top ten countries, reveals that Cameroon, Madagascar, Guinea, Ethiopia, Tanzania, and Malawl also have sizable carbon emissions due to deforestation (Table 12). Within these countries different zones are more or less important. If country emissions are compared in terms of tonnes of carbon per hectare, the relative ranking of countries changes drastically - Malawi, Liberia, Guinea, and Nigeria are all quite high in their emission rates per unit of land (Table 13).

Current carbon emissions from land-use change in Sub-Saharan Africa are about 5 times greater than emissions from fossil-fuel use (excluding South Africa). However, in a global context, carbon emissions from Sub-Saharan land-use change represent less than 5\% of current global carbon emissions from fossil fucl and less than 20\% of U.S. fossil-fucl cmissions.

\subsection{COMPARISON OF METHODOLOGY AND RESULTS WITH OTHER APPROACHES}

Continental-scale carbon accounting models have been developed by Houghton et al. $(1983,1985,1987)$ and Detwller and Hall $(1988)$. Both models are bookkecping models and do not include lactors controlling land use or determining carbon inventory. Thus the models can predict current and past emissions and are well suited for modeling global carbon cycles but are not well suited for examining land management options for carbon storage. Further, both models predict emissions at a continental scale, ${ }^{33}$ although the Houghton et al. model partitions the regional predictions into country emissions. Like the model presented in this paper (for this discussion referred to as the A.I.D. model), both models use the FAO/UNEP data on deforestation and forest inventory to describe rates of land-use change and land-use areas. Carbon storage values are forest type specific rather than geographically specific. For example, the Houghton model calculates an annual carbon emission value for Africa but differentiates three forest types - mojs! seasonal, and dry forests. Two sets of carbon values are associated with these types. One set of carbon storage values was based on continental growing stock volumes as reported by FAO/UNEP, while the other was based on an ecosystem biomass data base developed by Brown and Lugo (1984). The FAO-based carbon storage values are considerably lower than the ecosystem-based values and are considered to be more representative of reality (Brown 1988); they are also more similar to the values used in the A.I.D. model.

The Houghton model partitions the regional estimate of carbon emission among different countries on the basis of an index developed using the country-specific rates of deforestation and area of forest as given in the 1980 FAO/UNEP Forest Resources of Tropical Africa Report. The Houghton model accounts for the temporal dynamics of both decomposition and forest fallow regrowth and makes some very general calculations of soil carbon loss and carbon loss due to the conversion of forest fallow agriculture to

\footnotetext{
${ }^{33}$ The Detwiler and Hall model has been used to model individual country emissions in some cases (Detwiler and Hall 1988).
} 


\begin{tabular}{|c|c|c|c|c|c|c|c|c|c|c|}
\hline \multirow[b]{2}{*}{ Country } & \multicolumn{7}{|c|}{$\begin{array}{l}\text { Carbon emissions } \\
\left(10^{6} \text { tonnes } \mathrm{C}\right)\end{array}$} & \multicolumn{3}{|c|}{$\begin{array}{c}\text { Proportion of emission } \\
\text { among zones }\end{array}$} \\
\hline & 1991 & 1993 & 1995 & 1997 & 1999 & 2001 & Mean & Zone1 & Zone2 & Zone3 \\
\hline Zaire & 32.9 & 32.8 & 32.6 & 32.5 & 32.3 & 32.2 & 32.6 & 0.56 & 0.43 & . \\
\hline Ivory Coast & 31.7 & 27.4 & 23.7 & 20.5 & 17.7 & 15.3 & 22.7 & 0.86 & 0.14 & . \\
\hline Nigeria & 20.2 & 18.9 & 17.8 & 16.7 & 15.6 & 14.7 & 17.3 & 0.54 & 0.42 & 0.04 \\
\hline Madagascar & 8.7 & 8.5 & 8.3 & 8.1 & 7.9 & 7.7 & 8.2 & 0.37 & 0.63 & * \\
\hline Cameroon & 7.1 & 7.1 & 7.0 & 6.9 & 6.9 & 6.8 & 7.0 & 0.85 & 0.12 & 0.03 \\
\hline Guinea & 6.2 & 6.1 & 6.0 & 5.9 & 5.8 & 5.7 & 6.0 & 0.38 & 0.62 & . \\
\hline Ethiopia & 5.7 & 5.7 & 5.7 & 5.6 & 5.6 & 5.6 & 5.6 & 0.88 & 0.12 & - \\
\hline Tanzania & 5.6 & 5.6 & 5.5 & 5.5 & 5.5 & 5.4 & 5.5 & 0.00 & 0.86 & 0.14 \\
\hline Malawi & 5.8 & 5.4 & 4.9 & 4.5 & 4.1 & 3.8 & 4.8 & 1.00 & - & . \\
\hline Sudan & 3.3 & 2.6 & 2.1 & 1.7 & 1.4 & 1.1 & 2.1 & 0.64 & 0.33 & 0.13 \\
\hline $\begin{array}{l}\text { Sum of top ten } \\
\text { countries }\end{array}$ & 127.2 & 120.0 & 113.6 & 107.9 & 102.9 & 98.3 & 111.6 & \\
\hline Sum of all countries & 169.1 & 161.2 & 154.1 & 147.7 & 142.0 & 136.9 & 151.8 & & & \\
\hline
\end{tabular}

-There were no sampled points in zone 3 of Madagascar. 


\begin{tabular}{|c|c|c|c|c|c|}
\hline \multicolumn{2}{|c|}{1985} & \multicolumn{2}{|c|}{1993} & \multicolumn{2}{|c|}{2001} \\
\hline Country & Emissions & Country & Emissions & Country & Emissions \\
\hline Ivory Coast & 1.54 & Ivory Coast & 0.86 & Ivory Coast & 0.48 \\
\hline Malawi & 0,81 & Malawia & 0.57 & Malawi & 0.40 \\
\hline Liberia & 0.58 & Liberia & 0.48 & Liberia & 0.200 \\
\hline Guinea & 0.29 & Guinea & 0.27 & Guinea & 0.25 \\
\hline Nigeria & 0.27 & Nigeria & 0.21 & Ghana & 0.17 \\
\hline Ghana & $0.1 n$ & Ghana & 0.18 & Nigeria & 0.16 \\
\hline Rwanda & 0.16 & Rwanda & 0.16 & Cameroon & 0.15 \\
\hline Madagascar & 0.16 & Cameroon & 0.15 & Taire & 0.14 \\
\hline Cameroon & 0.16 & Madagascar & 0.15 & Madagascar & 0.13 \\
\hline Benin & 0.15 & Zaire & 0.14 & Togo & 0.13 \\
\hline Zaire & 0.15 & Benin & 0.14 & Rwanda & 0.12 \\
\hline Togo & 0.14 & Togo & 0.13 & Benin & 0.12 \\
\hline Equatorial Guinea & 0.09 & Sierra leone & 0.08 & Sierra Leone & 0.07 \\
\hline Sirrra Leone & 0.08 & Equatorial Guinea & 0.07 & Equatorial Guinca & 0.07 \\
\hline Senegal & 0.07 & Senegal & 0.07 & Senegal & 0.07 \\
\hline Mozambique & 0.07 & Tanzania & 0.06 & Gabon & 0.06 \\
\hline Tanzania & 0.06 & Gabon & 0.06 & Tanzania & 0.06 \\
\hline Gabon & 0.66 & Mozambique & 0.06 & Congo & 0.06 \\
\hline Congo & 0.06 & Congo & 0.06 & Mozambique & 0.06 \\
\hline Burkina Faso & 0.06 & Burkina Faso & 0.06 & Burkina Paso & 0.05 \\
\hline Zimbabwe & 0.05 & Zimbabwe & 0.05 & Zimbabwe & 0.05 \\
\hline Ethiopia & 0.05 & Ethiopia & 0.05 & Ethiopia & 0.05 \\
\hline Uganda & 0.05 & Uganda & 0.05 & Uganda & 0.05 \\
\hline Zambia & 0.05 & Zambia & 0.05 & Zambia & 0.05 \\
\hline Angola & 0.04 & Angola & 0.04 & Angola & 0.04 \\
\hline Kenya & 0.03 & Central African Rep. & 0.03 & Central African Rep. & 0.03 \\
\hline Central African Rep. & 0.03 & Kenya & 0.03 & Kenya & 0.02 \\
\hline Sudan & 0.03 & Sudan & 0.01 & Mali & 0.01 \\
\hline Mali & 0.01 & Mali & 0.01 & Chad & 0.01 \\
\hline Chad & 0.01 & Chad & 0.01 & Sudan & 0.00 \\
\hline Namibia & 0.00 & Namibia & 0.00 & Namibia & 0.00 \\
\hline Botswana & 0.00 & Botswana & 0.00 & Dotsisna & 0.00 \\
\hline Somalia & 0.00 & Somalia & 0.00 & Niger & 0.00 \\
\hline Niger & 0.00 & Niger & 0.00 & Somalia & 0.00 \\
\hline Burundi & 0.00 & Burundi & 0.00 & Burundi & 0.00 \\
\hline
\end{tabular}


permanent agriculture. In general, carbon losses from soil carbon losses are predicted to be about 10 to $30 \%$ of the carbon losses due to vegetation carbon loss. Carbon losses from conversion of forest fallow agriculture to permanent agriculture are based on Meyer's regional estimates of forest fallow to agricuiture conversion (Meyer 1980, 1984). Meyer's estimates would predict that the global area of forest-fallow agriculture is decreasing rapidly, while FAO indicates that it is increasing (Detwiler and Hall 1988, Houghton et al. 1987). The A.I.D. model does not use Meyer's data to address the conversion of forest fallow to permanent agriculture in part because of this confusion.

Estimates of 1980 country-level carbon emissions predicled by Houghton et al. (1987) are compared with the A.I.D. base-case model results for 1985 in Table 14. In spite of the very fundamental differenees between the two models, their carbon emission predictions are fairly similar. The top nine carbon-emitting countries are the same in both the studies, and the Houghton model predictions using the low set of storage values are just slightly higher than the country emission values predicted by the A.I.D. model. Discrepancies tend to arise with those countries for which Houghton et al. predicted significant carbon losses due to forest fallow conversion to permanent agriculture (Table 14). Because Houghton et al. considered soil carbon losses and the conversion of forest fallow to permanent agriculture, neither of which were considered in the A.I.D. model, one might expect Houghton predictions to be generally higher. The reason their predictions are not always higher may be because of the higher storage carbon values used for forest fallow in the Houghton model.

Consequently, the carbon release from the conversion of forest to forest fallow in the Houghton model may not be as large a release as in the A.I.D. model. Although it is not completely clear from the description of the Houghton model, it would appear that most of the deforestation in the model is attributed to the conversion of forest to forest fallow rather than to permanent agriculture. This assumption would also reduce the carbon emissions relative to the A.I.D. model.

The predictions of the Detwiler and Hall model cannot be compared with the A.I.D. base case model results because Detwiler and Hall present their model predictions in terms of the entire tropical region of the world. It should be noted, however, that they estimate lower losses of carbon due to deforestation in the tropics than does Houghton et al. (1987). Detwiler and Hall present a range of $4(0)$ to 1600 million tonnes of carbon emitted in 1980 from land-use change in the tropics, while Houghton et al. predict $9(0)$ to 2500 million tonnes. The difference can be mainly attributed to the carbon values assigned the different forest types and the modeling of forest fallow agriculture. The extent, carbon content, and rate of loss or creation of forest fallow agriculture are poorly understood. It is one of the main factors contributing to the uncertainty surrounding carbon emissions from land-use change in tropical countries.

Because of the subject of the A.I.D. model, a rigorous validation is impossible. However, conlidence in the A.I.D. model's ability to correctly model land-use dynamics and carbon emission is strengthened by the similarity of various models' predictions. Consequently, the model appears to be both a useiul and appropriate vehicle for evaluating carbon emission resulting from different land-use scenarios. 


\begin{tabular}{|c|c|c|c|c|c|}
\hline \multicolumn{2}{|c|}{ AID model } & \multicolumn{4}{|c|}{ Houghton et al.'s model } \\
\hline \multirow[t]{2}{*}{ Country } & \multirow[t]{2}{*}{$\begin{array}{c}\text { Emissions } \\
\text { (million tonnes } \mathrm{C} \text { ) }\end{array}$} & \multirow[t]{2}{*}{ Country } & \multicolumn{3}{|c|}{$\begin{array}{c}\text { Emissions } \\
\text { (million tonnes } C \text { ) }\end{array}$} \\
\hline & & & Low & Mid & High \\
\hline Ivory Coast & 48.9 & Ivory Coast ${ }^{\mathrm{a}}$ & 62.1 & 100.5 & 138.5 \\
\hline Zaire & 33.4 & Nigeria $^{a}$ & 36.8 & 59.5 & 82.0 \\
\hline Nigeria & 24.4 & Zaire & 21.6 & 35.0 & 48.2 \\
\hline Madagascar & 9.3 & Sudan & 16.4 & 26.6 & 36.7 \\
\hline Malawi & 7.6 & Madagascar ${ }^{A}$ & 14.3 & 23.2 & 32.0 \\
\hline Cameroon & 7.3 & Malawi & 9.7 & 15.7 & 21.6 \\
\hline Guinea & 6.6 & Cameroon & 9.6 & 15.6 & 21.5 \\
\hline Sudan & 6.1 & Guinea $^{a}$ & 5.4 & 8.8 & 12.1 \\
\hline Ethiopia & 5.9 & Ethiopia & 4.8 & 7.8 & 10.7 \\
\hline T'anzania & 5.7 & Literia" & 4.8 & 7.8 & 10.7 \\
\hline Liberia & 5.6 & Ghana $^{a}$ & 4.8 & 7.7 & 10.6 \\
\hline Angola & 5.3 & Mozambique & 4.3 & 7.0 & 9.6 \\
\hline Mozambique & 5.1 & Angola & 3.4 & 5.5 & 7.6 \\
\hline Ghana & 4.4 & Tanzania & 3.0 & 4.9 & 6.8 \\
\hline Tambia & 3.5 & Zimbabwe & 2.6 & 4.2 & 5.8 \\
\hline Zimbabwe & 2.1 & Zambia & 2.6 & 4.2 & 5.8 \\
\hline Congo & 2.0 & Chad & 2.6 & 4.2 & 5.8 \\
\hline Central African Rep. & 1.9 & Burkina Faso & 2.6 & 4.2 & 5.8 \\
\hline Kenya & 1.9 & Central African Rep. & 2.2 & 3.6 & 5.0 \\
\hline Benin & 1.7 & Congo & 2.1 & 3.4 & 4.7 \\
\hline Gaton & 1.6 & Senegal & 1.8 & 2.9 & 4.0 \\
\hline Burkina Faso & 1.6 & Benin $^{\mathrm{a}}$ & 1.5 & 2.5 & 3.4 \\
\hline Senegal & 1.4 & Gabon & 1.4 & 2.2 & 30 \\
\hline Uganda & 1.0 & Uganda & 1.4 & 2.2 & 3.0 \\
\hline Mali & 0.9 & Mali & 1.3 & 2.1 & 2.9 \\
\hline Chad & 0.8 & Kenya & 1.1 & 1.7 & 2.3 \\
\hline Togo & 0.8 & Niger & 1.0 & 1.6 & 2.2 \\
\hline Sierra Lcone & 0.6 & Namibia & 0.6 & 1.0 & 1.4 \\
\hline Rwanda & 0.4 & Somalia & 0.6 & 1.0 & 1.4 \\
\hline Niger & 0.4 & Sierra Leone ${ }^{\mathrm{a}}$ & 0.6 & 1.0 & 1.4 \\
\hline
\end{tabular}




\begin{tabular}{||l|r|r|r|r|r||}
\hline \multicolumn{2}{|c|}{ Table 14. Comparison and ranking of carton emissions predicted by AID model and Houghton model. The Hloughton values } \\
are for 1980, whereas the AlD values are for 1985.
\end{tabular}

"Emission value includes emissions from the conversion of fallow forest agriculture to permanent agriculture. For lvory Coast $42 \%$ of the total emissions are due to this land-use conversion; for Nigeria, 45\%; Madagascar, 47\%; and Trogn, 33\%. 


\subsection{EVALUATION OF LAND-USE MANAGEMENT OPTIONS}

Land-use management options that are analyzed in the context of sequestering and preserving stores of carbon include (1) preservation of natural forests, (2) agroforestry and fuelwood, and (3) reforestation for industrial wood production. The first option is concerned with identifying areas of natural forest for protection and improved management (reducing the deforestation rates). Greater preservation of natural forest areas would not only continue to store carbon but would also serve to protect watersheds and limit crosion, provide buffers against desertification, and maintain biodiversity and habitat. The latter two options are more specific land-use alternatives designed to miligate development pressures and spontaneous encroachment as well as to sequester carbon. For each land-use option, the base-case model was modified. The modifications to the base-case model, the carbon results, and the estimated costs of the specific land-use option are discussed in the remainder of this section.

\subsubsection{Preservation of Natural Forests}

The demand for agricultural land is a principal cause of deforestation in Sub-Saharan Africa. Without any external pressure to adopt more sustainable and productive agricultural systems, rural populations are forced to clear new forest areas and to use more marginal land that may not be suitable for cultivation. ${ }^{34}$ Rural populations also invade the forests and open woodlands in search of fuclwood. As noted earlier, fuelwood (firewood and wood for charcoal production) accounts for over $60 \%$ of total encrgy consumption in Sub-Saharan Africa. Fuelwood is gathered to satisfy one's own energy needs as well as to satisfy the charcoal demands of rapidly growing urban populations. ${ }^{35}$ Charcoal production is particularly destructive since it usually involves the use of whole trees and not the use of scavenged limbs and branches. In more arid regions, the removal of forest vegetation increases runoff and crosion and exacerbates problems of erratic rainfall common to these arcas. ${ }^{36}$

Secondary to the demand for new agricultural land and fuelwood, the demand for timber products also contributes to the loss of forest area. Many governments compelled to generale forcign exchange earnings and employment have looked toward the forests as a

\footnotetext{
${ }^{34}$ Problems of low-productivity agriculture and declining soil fertility are exacerbated by patterns of land tenure. Because many subsistence farmers do not own their land or do not have long-term land rights beyond current-use rights, they lack the incentive to protect fallow land and to practice soil-conserving measures.

${ }^{35}$ Urban energy consumption is growing at an annual rate of over 5\% (Armitage and Schramm 1989).

${ }^{36}$ In the Sahelian and Sudanian zones of Africa, consumption of wond now greatly exceeds natural regeneration and threatens the area with desertification (Anderson and Fishwick 1984).
} 
resource that can readily be exploited (Repetto and Gillis 1988). ${ }^{37}$ Favorable concessions as well as policies to stimulate the growth of wood processing industries have been used. These policies, which open up the forest to logging, also create and accelerate aceess, enabling subsistence farmers to incorporate these areas into the cycle of forest fallow cultivation and, as population density increases, into bush and short fallow agriculture.

To investigate this land-use option in terms of carbon storage and emissions, a range of preservation scenarios is evaluated in which deforestation rates are reduced and/or degraded native forest is protected and allowed to recover. The base-case model was modified to (1) change the relative rates of delorestation and/or (2) allow the existing degraded forests to recover their biomass (i.c., the carbon storage value of forest land at points that had been degraded was gradually increased each year at a rate defined by the potential productivity of that site until the carbon storage value of the forest equaled that of undegraded forest). Seven additional runs of the model were made, setting the deforestation rates to either 0 (none), $75 \%$ (low), $50 \%$ (moderate) or $100 \%$ of the current rate and allowing the existing degraded forest to recover or not recover. Of course, $100 \%$ of the current deforestation rate with no biomass recovery is the basc-case run discussed earlier. For cach of the applicable secnarios, the rate of recovery (i.c., the annual increase in carbon storage) was defined as follows:

$$
\text { GROW }_{z}=5 *\left(\operatorname{RAIN}_{\mathrm{z}} / 3(0)(0)\right)^{*} \operatorname{SOIL}_{\mathrm{z}} /\left(2 * \mathrm{SOIL}_{\mathrm{z}}-1\right)
$$

where

$\mathrm{GROW}_{z}=$ unit of annual increase in carbon storage of recovering forest at point $\mathrm{z}$, SOIL $_{\mathrm{z}}=$ soil fertility class at point $z$,

RAIN $_{z}=$ annual rainfall in millimeters at point $z$.

This equation assumes the maximum rate of recovery would be 5 tonnes $\mathrm{C} / \mathrm{ha} / \mathrm{yr}$ under conditions of good soils and rainfall of $3000 \mathrm{~mm} / \mathrm{yr}$. This upper limit is then reduced by less rainfall or less than ideal soils.

Figure 14 summarizes carbon emissions assuming no change from the current situation and a complete halt of all deforestation and the recovery of degraded forests beginning in 1990). The estimated mean annual carbon emissions are approximately 152 million tonnes between 1991 and 2001 without forest preservation. With preservation (a complete halt to deforestation), the emissions become negative (mean annual sequestering rate of 62.5 million tonnes) because the degraded forests serve as a carbon sink as they recover their original biomass. However, the magnitude of the sink will become smaller and eventually reach zero as the degraded forests reach their maximum biomass and are no longer increasing in size and storing carbon. Of course, the degree to which degraded forests will act as a sink and store

${ }^{37}$ The export of forest products, a major source of foreign exchange for some Sub-Saharan countries, is expected to decline in the future because of inadequate attention and management of the forest iesource base (WRI/IIED 1985). In Sub-Saharan Africa, four West African countries (Gabon, Ghana, Ivory Coast, and Liberia) account for nearly all of timber exports from the continent (Repetto and Gillis 1988). 


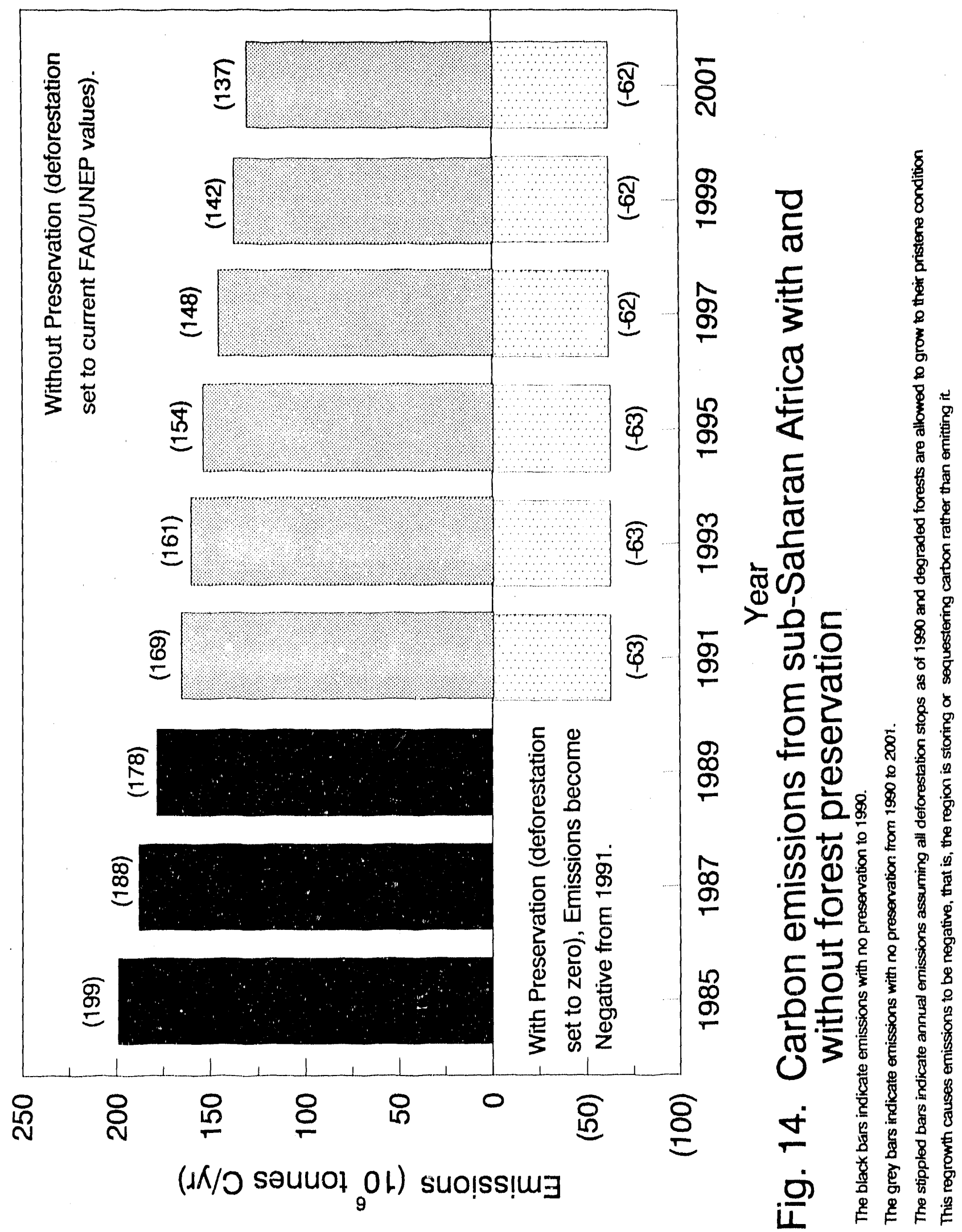


carbon depends on what portions of forests are considered degraded, the extent to which they are degraded, and the rate at which the forest can recover. ${ }^{38}$ To place these emissions in perspective, the carbon-sequestering potential of completely halting deforestation in SubSaharan frica is equivalent to about $5 \%$ of current annual fossil fucl carbon emissions from the United States. Moreover, the sequestering potential of these recovered forests are shortlived. Onee the trees are fully mature, they will no longer eontinue to sequester carbon, serving only to store carbon.

The mean annual savings in carbon emissions between 1991 and $2(0) 1$ for all preservation secnarios (deforestation rates set $100,25 \%, 50 \%$, and $10(0) \%$ of the current rate and with and without biomass recovery) and the base case (152 million tonnes) is summarized in Fig. 15. Reducing country deforestation rates to zero and allowing recovery results in a mean yearly sequestering of 62.5 million tonnes (0 tonnes if no recovery) over the 10 -yr time frame. The change in carbon emissions from this scenario would be approximately 154 million tonnes each year. Reducing deforestation rates by 75 and $50 \%$ results in a mean annual sequestering of 19 million tonnes (emissions of 43 million tonnes if no recovery) and emissions of 21 million tonnes (emissions of 83 million tonnes if no recovery), respectively. The change in carbon emissions relative to the base case is 110 million tonnes for the $75 \%$ reduction scenario and 70 million tonnes for the $50 \%$ reduction secnario.

Preservation of tropical forests depends largely on the possibility and feasibility of managing them as a sustainable system through natural regeneration, while providing the raw material for a large-scale, rurally located, viable forest-products industry (Leslic 1987, Maitre 1987, FAO 1987). That is, forests must be managed to satisfy the needs of locial populations where economic production and local industries are dependent on a sustainable yield of forest products and the suceess of the protected area and its enforcement is a matter of local concern (Wilkinson 1985). At a minimum, the costs of controlling deforestation and preserving existing forests would include direct management and protection expenses, as well as the costs of programs for addressing the causes of forest encroachment and destruction. One very broad range of cost estimates lor preserving a naturally managed forest was reported to vary from $\$ 20$ to $\$ 1(k) /$ ha, with annual recurring expenses for administration and management of $\$ 0.50$ to $\$ 1.50 /$ ha (Leslic 1987). ${ }^{30}$ Using these estimates, life-cycle costs of preservation for each hectare of land would range between $\$ 25$ and $\$ 115$, assuming a $10 \%$ real discount rate. It should be stressed that these cost estimates are just the direct expenses for oversecing the managed forest area and do not include the costs of concomitant policies to deal with or to remove development and encroachment pressures (e.g., development of sustainable agricultural systems, promotion of local forest products industries).

The additional forest area preserved in year 2001 under a complete cessation of deforestation, a $75 \%$ reduction in deforestation, and a $50 \%$ reduction in deforestation beginning in 1990 is shown in Table 15 . Using the above cost estimates, the direct

${ }^{38}$ It was assumed that a degraded forest had $65 \%$ of the biomass of an undegraded forest.

${ }^{35}$ The costs of direct management and protection expenses are highly site-specific. Developing more precise estimates would require inclusion of considerable local information. Moreover, this added detail would be inconsistent with the precision of the carbon estimates. 


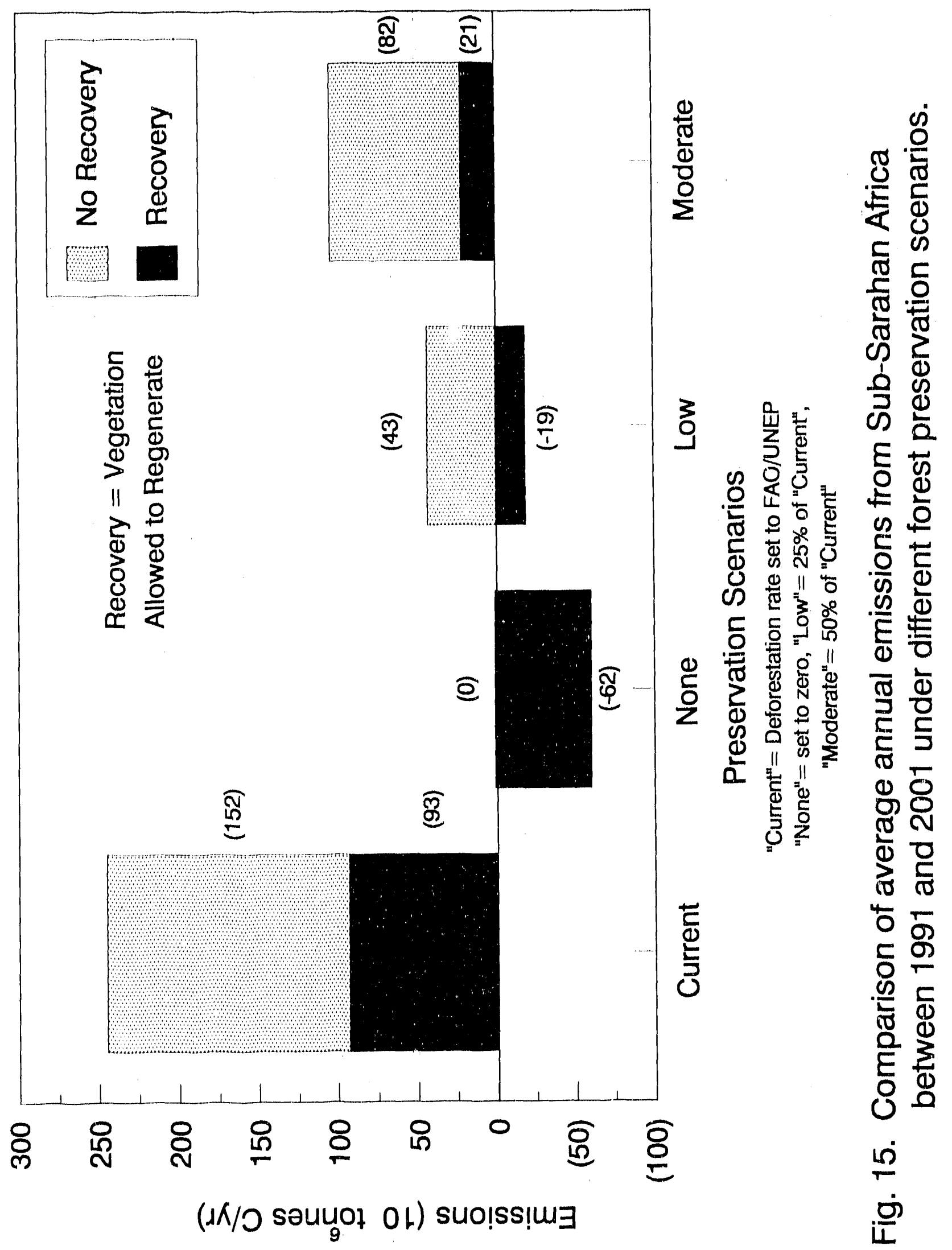


Table 15. Additional land (millions of hectares) In forest in 2(k)1 under different deforestallon reduction scenartos. NONE $=$ deforestation rate set to $\%$ ero in 199(), L.OW = deforestation rate set to 25\% of CURREN'T, MODERA'TE = deforestation rate set to 50\% of CURREN'T. CURREN'T" = deforestation rate set to $198.5 \mathrm{FAO} / \mathrm{UNEP}$ values.

\begin{tabular}{|c|c|c|c|}
\hline Country & $\begin{array}{c}\text { NONE } \\
\text { compared to } \\
\text { CURREN'T }\end{array}$ & $\begin{array}{c}\text { LOW } \\
\text { compared } 10 \\
\text { CURREN'T }\end{array}$ & $\begin{array}{l}\text { MODERA'TE } \\
\text { compared Io) } \\
\text { CURRISN'I }\end{array}$ \\
\hline Angola & 1.18 & 0.88 & 0.58 \\
\hline Benin & 0.70 & 0.51 & 0.33 \\
\hline Botswana & 0.40 & $(0.30$ & 0.20 \\
\hline Burundi & 0.01 & $(0.1) 1$ & 0.01 \\
\hline Camcroon & 1.07 & 0,80 & 0.5 .3 \\
\hline Contral Africian Rep. & 0.6 .3 & $(0.49$ & $(0.31$ \\
\hline Chad & 0.74 & 0.54 & 0.36 \\
\hline Congo & 0.26 & 0.20 & (1).1.3 \\
\hline Equatorial Gulnca & 0.014 & $(0.1) .3$ & $(0.1) 2$ \\
\hline Ethopla & 0.97 & $(1.72$ & 0.48 \\
\hline Gabon & 0.17 & 0.13 & $0 .(1)$ \\
\hline Cihana & 0.66 & $(0.49$ & $(0.32$ \\
\hline Guinea & 0.98 & $(1.7 .3$ & 0.49 \\
\hline Ivory Coasi & 3.601 & 2.42 & 1.44 \\
\hline Kenya & 0.39 & 0.28 & 0.19 \\
\hline Liberia & 0.43 & $(0.31$ & (1).20) \\
\hline Maddagascar & 1.54 & 1.14 & 0.75 \\
\hline Malawi & 1.25 & 0.88 & 0.55 \\
\hline Mall & 0.36 & 0.27 & 0.18 \\
\hline Mozambique & 1.25 & 0.92 & 0.61 \\
\hline Namibia & 0.6 .3 & 0.47 & $(0.31$ \\
\hline Niger & 0.44 & 0.32 & $(0,20$ \\
\hline Nigeria & $3 .(01$ & 2.29 & 1.37 \\
\hline Rwanda & 0.06 & 0.04 & 0.02 \\
\hline Senegal & 0.47 & 0.3 .5 & 0.2 .3 \\
\hline Sicra Leonc & 0.07 & $0.1 \%$ & 0.04 \\
\hline Somalla & 0.16 & 0.12 & 0,08 \\
\hline
\end{tabular}


Table 15. Additional land (millions of hectares) In forest in $2(x) 1$ under different deforestation reduction secnarlos. NONE $=$ deforestation rate set $10 \%$ \%ero in 199(), LOW $=$ deforestation rate set to $25 \%$ of CURRENT, MODIERATE = deforestation rate set to $50 \%$ of CURRENT. CURRENT = deforestation rate set to 1985 FAO/UNEP values.

\begin{tabular}{|c|c|c|c|}
\hline Country & $\begin{array}{c}\text { NONE } \\
\text { compared } 10 \\
\text { CURRENT }\end{array}$ & $\begin{array}{c}\text { LOW } \\
\text { comparcd } 10 \\
\text { CURRENT }\end{array}$ & $\begin{array}{l}\text { MODERATTE } \\
\text { Compared Io } \\
\text { CURRENT' }\end{array}$ \\
\hline Sudan & 1.75 & 1.11 & 0.6 .3 \\
\hline Tunzania & 1.57 & 1.17 & 0.78 \\
\hline Togo & 0.14 & 0.10 & $0 .(16)$ \\
\hline Uganda & 0.57 & 0.42 & 0.28 \\
\hline Rwanda & 0,06 & $0 .(14$ & $0 .(12$ \\
\hline Zulre & 4.50 & 3.37 & 2.24 \\
\hline Zambia & 0.86 & 0,64 & 0.4 .3 \\
\hline Zlmbabwe & 0,80 & 0.60 & 0.40 \\
\hline TOTAL. & 32.21 & 23.52 & 15.11 \\
\hline
\end{tabular}


preservation costs can be approxlmated for cach of the preservation seconarlos. For example, If a $50 \%$ reduction in deforestation rates is considered within the realm of possibility (i.e., an all-out concerted eflort), the Impact in terms of carbon embssions would be about 70 million connes annually or about $1.5 \%$ of eurrent world emissions. The total direct preservation eosts would lie between $\$ 380$ and $\$ 16 \%$ million for the 15.1 millon hectares with a cost for each tonne of earbon stored of $\$ 310$ \$ $\$ 15 /$ tonne. As noted earlier, appreximately one halle of emissions and one thitrd of the preserved land areas would lie in just three countries - Zaire, Ivory Coast, and Nigeria. Foousing preservalion ellorts on a limited number of countries could reduce costs. Costs could be further redened il' only liorest areas in eminent danger of encronchment and exploitation were singled out for preservation. Direct preservation costs for the $I(x)$ and $5(1) \%$ deforestation rate reduction seconarios would be proportionately higher.

\subsubsection{Agroforestry and Fuclwoxd}

The agrolorestry land-use options that are mose relevant to this study are those that pertain to the humid and subhumid troples and to the tropical highlands." For these higher biomass preductivily areas, alley cropping and other spatial tree crop arrangements (e.g., incerstitial plantingss) have the potential lo secpuester carbon and/or slow the rate of agricullurally induced deforestalion, and to provide a wide range of by-products (i.e., l'ruit, fordeler, and fuelwood). Moreover, if leguminous trees are planted, they are a potential source ol' nitrogen and other nutrients for erops."

Since trees are considered a permanent feature of the landscape, there is a potential for seguestering carbon in direct proportion to the spatial arrangement of the trees. Although there are manj possible spatial arrangements for trees and crops, a typical arrangement is 10 have a closer in-row spacing $(162.5 \mathrm{~m})$ and a wider belween-low spacing $(2 \mathrm{lo} 5 \mathrm{~m}) \mathrm{lo}$ allow for crops. Under the closest spacings ( $1 \mathrm{~m} \times 2 \mathrm{~m}$ ), trees would oceupy appreximately hall' of the planted area, which would eontain about $5(K)$ trees per heclate alssuming a tree row width ol' aboul $1 \mathrm{~m}$. 'There would be approximalely $8($ th) trees per hectare under the wider spatial arrangements.

A tenct of agrolorestry is sustainability - improving soil structure and fertility, crealting a more faverable macroclimate and microclimate, reducing the rate of decline in soil productivily, and providing a renewable sourec of luelwood and fodder. It can be argued that increasing or at least maintaining agricultural productivity of' a given land area would have a

\footnotetext{
"Agrosilvopastoral and silvopastoral systems, although important for controlling crosion and providing windbreaks and shelter in the Sudano/Sahelian zones, are not key options for carbon secuestering, given their low inherent biomass productivity.

"Increases in yields have been demonstrated when trees were planted in association with agricultural crops. Although the elfect of this association has not been adequately defined, some results suggest a substantial increase in crop yickds despite a net loss in land area devoted to crops (Leach and Mearns 1988). For example, Torres (1983) in experiments with leuciana, reported that maize yickds increased from 5 to $16 \mathrm{kgs}$ for cach $\mathrm{kg}$ of organic nitrogen added. Results of other studies show a neutral eflect, and still other studies report that the area lost to cropping from the trees is not made up by higher productivity (Lal 1989).
} 
land-stabilizing presence and lessen the need to clear new forest lands for cultivation, thereby reducing forest encroachment and the rate of deforestation. The impact of agroforestry on reducing the rate of deforestation would be exceedingly diflicult to estimate with any degree of precision. At a minimum, information would be required on local population growth rates, land tenure and ownership palterns, socioeconomic factors, and stabilization and agricultural productivily effects from agroforestry. Determining specific estimates of these effects from agroforestry interventions is beyond the scope of this study and is more appropriately investigated at a country or specilic zonal level. Consecquently, no attempt is made to inclinde these effects in the model analysis of agroforestry.

To model the impact of agroforestry, a new land-use class (called "agroforestry") was incorporated into the model. This land-use class was created from nonforest land at points that mol the following criteria:

1. The nonlorest vegetation was most likely agriculture rather than native vegetation. This restriction was accomplished by excluding points that were $10(0) \%$ nonforest native vegetation.

2. The point is focated in a country and zone targeted for agroforestry.

The countries for which the agroforestry land-use management option is cvaluated for carbon secpuestering are listed in Table 16. These countries are believed to have some of the necessary requisites to adopt agroforestry and fuelwood programs (FAO 1982, FAO 1984b, FAO 1987, de Montalembert and Clement 1983).

For these countries where agroforestry is evaluated as a land-use option, an average secedling spacing of $4 \mathrm{~m}$ between rows, a $1-\mathrm{m}$ in-row spacing, and a tree row width of $1 \mathrm{~m}$ is assumed. 'This spatial arrangement would correspond to a tree-planting density of approximately $1(x)($ trees per hectare. It is further assumed that the trecs would accumulate approximately 20 or $40 \%$ of the carbon of a mature tree plantation at that sitc. The carbon associated with a plantation at a site was a function of the potentlal forest plantation productivity of the site. If the potential site productivity was greater than 8 tonnes $\mathrm{C} / \mathrm{ha} / \mathrm{year}$ inen the plantation carbon storage was assumed to be 120 tonnes $C /$ ha, if less than 8 but gi sater than 6 tonnes $\mathrm{C} /$ ha/year then 100 tonnes C/ha, if less than 6 but greater than 4 tonnes C/la/year then 9() tonnes $\mathrm{C} / \mathrm{ha}$, and if less than 4 tonnes C/ha/year then 85 tonnes $\mathrm{C} / \mathrm{ha}$. These carbon storage values are based on tropical plantation biomass statistics (Lago et al. 1988). Potential profuctivity of a site was calculated with the following equation:

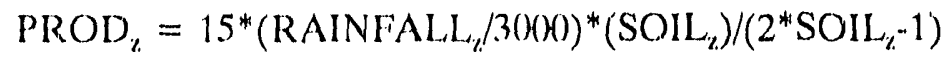

where

PROD ${ }_{2}=$ potential fores productivity in tonnes of carbon per hectare per year at point $z$,

RAINFALL $=$ annual rainfall in millimeters at point $z$,

SOIL $_{z}=$ soil fertility class at point $z$,

$\mathrm{z}=$ location of point. 


\begin{tabular}{|c|c|}
\hline \multicolumn{2}{|c|}{$\begin{array}{c}\text { Table 16. Countries and zones in which agroforestry was } \\
\text { implemented }\end{array}$} \\
\hline Country & Zone \\
\hline Botswana & 1,2 \\
\hline Burkina Faso & 1 \\
\hline Burundi & 1 \\
\hline Cameroon & 1 \\
\hline Chad & 1 \\
\hline Ethiopia & 1 \\
\hline Gambia & 1 \\
\hline Ghana & 1,3 \\
\hline Guinca & 1 \\
\hline Ivory Coast & 1 \\
\hline Kenya & 1,2 \\
\hline Madagascar & 1 \\
\hline Malawi & 1 \\
\hline Mali & 1 \\
\hline Mozambique & 3 \\
\hline Nigeria & $1,2,3$ \\
\hline Rwanta & 1 \\
\hline Senegal & 1 \\
\hline Somalia & 1 \\
\hline Sudan & 1 \\
\hline Tanzania & $1,2,3$ \\
\hline Togo & , \\
\hline Uganda & $?$ \\
\hline Zaire & 2 \\
\hline Zambia & $\mathbf{i}$ \\
\hline
\end{tabular}

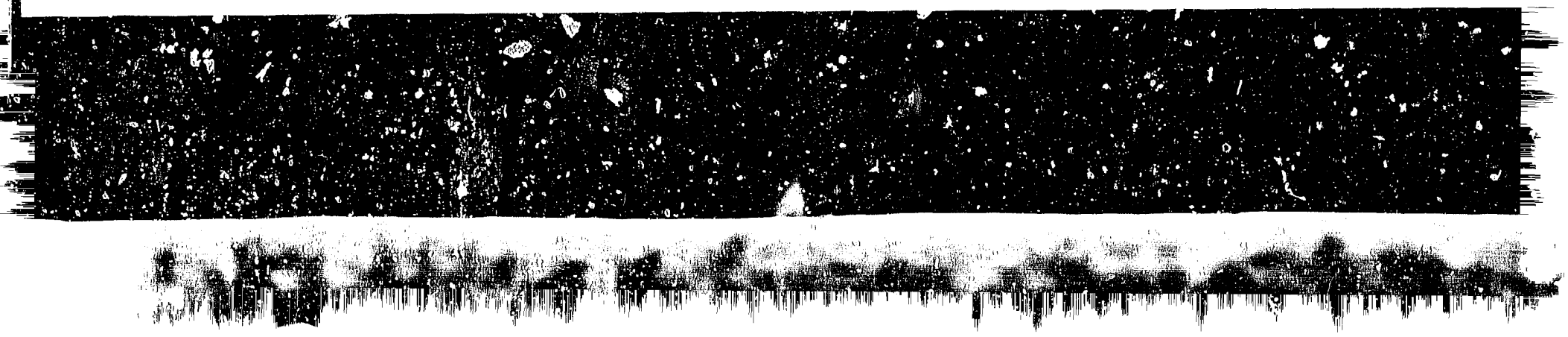


This equation assumes the maximum potential forest productivity at any site is 15 tonnes $\mathrm{C} /$ ha/year and this will only occur if the soils are good and the rainfall is $3000 \mathrm{~mm} / \mathrm{year}$. This upper limit is then reduced by less-than-ideal rainfall or soils. Yields of 15 tonnes $\mathrm{C} / \mathrm{ha} / \mathrm{year}$ have been observed in highly managed tropical plantations (Lugo et al. 1988).

Four agroforestry scenarios were run - two rates of agroforestry adoption and two amounts of stored carbon. It was assumed that each year either 2 or $4 \%$ of the land that met the above criteria was converted to agroforestry. It was then assumed that the carbon storage value associated with the agroforestry land-use class was the crop carbon storage (5 tonnes C/ha) plus either 20 or $40 \%$ of the carbon storage associated with a mature tree plantation. These numbers were chosen to reflect the previously described planting densities. They assume that the trees would be pruned back arid thus the carbon storage per unit area would be less than if the trees were allowed to grow to full maturity. The model does not trace the growth of the planted trees; rather, it assumes that the year the option is implemented is the year the carbon is accrued. There is no additional carbon stored in subsequent years unless new land is assigned to agroforestry. This simplification allows better comparison of the overall carbon benefits of agroforestry with other land-use options and the base case.

The total amount of land in agroforestry for each country and zone in the year 2001 under the two rates of agroforestry adoption is shown in Table 17. The low adoption (2\%/year) and the high adoption (4\%/year) scenarios would result in 26.2 and 47.3 million hectares in agroforestry by the end of $2(0) 1$, respectively. Four countries (Botswana, Chad, Nigeria and Zambia) would account for over $40 \%$ of the agroforestry land area. The increase in Sub-Saharan carbon inventory and the decrease in regional carbon emissions as a consequence of adopting agroforestry is shown in Table 18 for the four agroforestry scenarios and the base-case. Relative to the base case, agroforestry has the potential to reduce carbon emissions by 25 to $87 \%$ and increase the total carbon inventory by 0.6 to $2.1 \%$.

The minimum costs of implementing a program to encourage agroforestry would include the costs of developing nurseries to produce tree seedlings, transportation and distribution expenses to get the seedlings to the farmers, and training and extension services to ensure the seedlings are properly planted and tended. A program could also include incentive payments to farmers to encourage tree plinting and to provide the necessary maintenance (e.g., weed control) and purchase agreements for wood products (building poles, charcoal, etc.). However, these latter costs are not considered. Specific costs will be a function of the availability of seeds of appropriate species, the technology and material used in producing seedlings, the number of nurseries, the distribution expenses, and the number of farmers that are targeted for extension services. Anderson (1987) summarizes farm forestry costs for Nigeria. His estimates indicate production costs of $\$ 0.13$ per seedling with training, extension, and management expenses of $\$ 0.12$ per seealing. These costs are for a semiarid zone and therefore may not be representative of more favorable growing conditions. In contrast, Leach and Mearns (1988) cite agroforestry project costs of $\$ 0.03$ to $\$ 0.11$ per seedling. ${ }^{42}$ For this stidy, the direct costs for establishing each hectare of agroforestry land.

\footnotetext{
${ }^{42}$ Energy sector studies conducted by the UNDP/World Eank generally show similar cost estimates. Armitage and Schramm (1989) report government fiscal cost of small-farmer woodlots of about $\$ 100$ per hectare (198 'kwacha) in Malawi.
} 


\begin{tabular}{|c|c|c|c|}
\hline Country & Zone & $\begin{array}{c}\text { Low adoption } \\
\text { (million ha) }\end{array}$ & $\begin{array}{l}\text { High adoption } \\
\text { (million ha) }\end{array}$ \\
\hline Botswana & $\begin{array}{l}1 \\
2\end{array}$ & $\begin{array}{l}0.02 \\
3.81\end{array}$ & $\begin{array}{l}0.03 \\
6.85\end{array}$ \\
\hline Burkina Faso & $\begin{array}{l}1 \\
2\end{array}$ & $\begin{array}{c}1.08 \\
-\end{array}$ & $\begin{array}{c}1.95 \\
-\end{array}$ \\
\hline Burundi & 1 & 0.47 & 0.84 \\
\hline Cameroon & $\begin{array}{c}1 \\
2 \& 3\end{array}$ & $\begin{array}{c}0.35 \\
- \\
\end{array}$ & $\begin{array}{c}0.64 \\
- \\
\end{array}$ \\
\hline Chad & $\begin{array}{c}1 \\
2 \& 3\end{array}$ & 2.94 & $\begin{array}{c}5.28 \\
-\end{array}$ \\
\hline Ethiopia & $\begin{array}{l}1 \\
2\end{array}$ & $\begin{array}{c}0.57 \\
-\end{array}$ & $\begin{array}{c}1.02 \\
-\end{array}$ \\
\hline Ghana & $\begin{array}{l}1 \\
2 \\
3 \\
\end{array}$ & $\begin{array}{c}0.02 \\
- \\
<0.01 \\
\end{array}$ & $\begin{array}{c}0.04 \\
- \\
<0.01\end{array}$ \\
\hline Guinca & $\begin{array}{l}1 \\
2\end{array}$ & 0.08 & 0.15 \\
\hline Ivory Coast & $\begin{array}{l}1 \\
2 \\
\end{array}$ & $\begin{array}{c}0.07 \\
- \\
\end{array}$ & $\begin{array}{c}0.13 \\
- \\
\end{array}$ \\
\hline Kenya & $\begin{array}{l}1 \\
2\end{array}$ & $\begin{array}{l}0.10 \\
0.01\end{array}$ & $\begin{array}{l}0.18 \\
0.02\end{array}$ \\
\hline Madagascar & $\begin{array}{c}1 \\
2 \& 3 \\
\end{array}$ & $\begin{array}{c}0.32 \\
- \\
\end{array}$ & $\begin{array}{c}0.58 \\
- \\
\end{array}$ \\
\hline Mali & $\begin{array}{c}1 \\
2 \& 3\end{array}$ & $\begin{array}{c}1.14 \\
-\end{array}$ & 2.05 \\
\hline Malawi & 1 & 0.70 & 1.26 \\
\hline Mozambique & $\begin{array}{c}1 \& 2 \\
3\end{array}$ & 0.01 & $\overline{0.02}$ \\
\hline
\end{tabular}




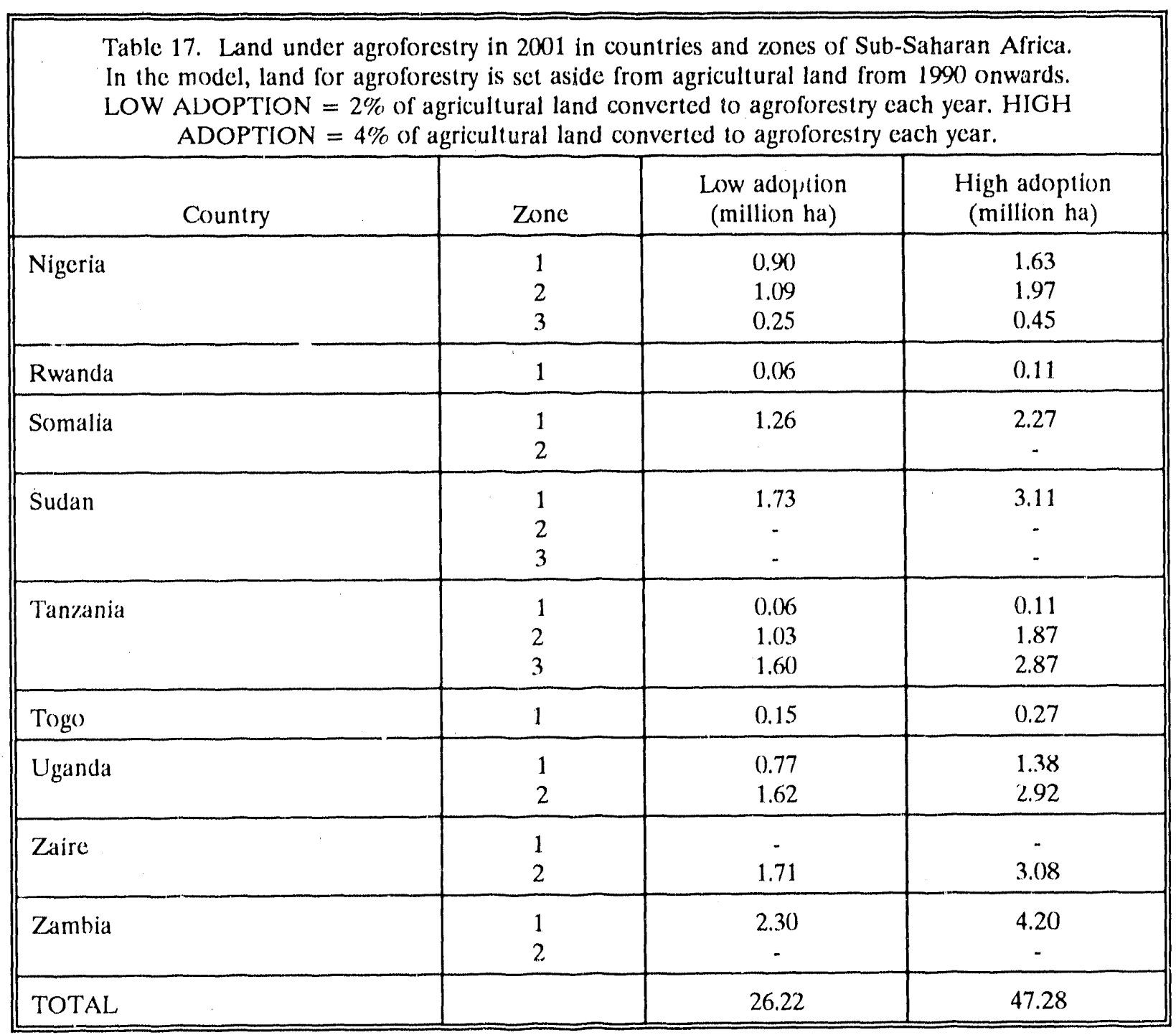




\begin{tabular}{|c|c|c|c|c|c|c|c|c|c|c|}
\hline 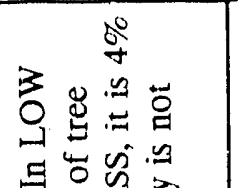 & 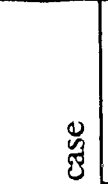 & 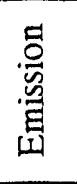 & $\overrightarrow{8}$ & $\begin{array}{l}\tilde{1} \\
\stackrel{-}{0}\end{array}$ & $\begin{array}{l}7 \\
\mathrm{f} \\
\end{array}$ & $\begin{array}{l} \\
\stackrel{+}{\Psi} \\
\end{array}$ & $\overrightarrow{\vec{v}}$ & \begin{tabular}{l|}
0 \\
0 \\
0 \\
-1
\end{tabular} & $\begin{array}{l}\vec{a} \\
\vec{\sigma}\end{array}$ & $\frac{9}{\vec{n}}$ \\
\hline 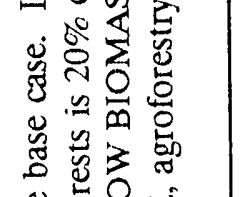 & 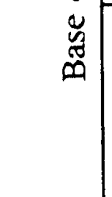 & $\begin{array}{l}\text { 宫 } \\
\stackrel{0}{0 .} \\
\text { 量 }\end{array}$ & $\begin{array}{l} \\
8 \\
8 \\
\end{array}$ & $\begin{array}{l}0 \\
0 \\
0 \\
0 \\
n\end{array}$ & 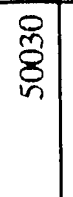 & $\begin{array}{l}0 \\
0 \\
\frac{2}{\sigma}\end{array}$ & $\begin{array}{l}q \\
q \\
q\end{array}$ & $\frac{8}{\frac{8}{9}}$ & $\begin{array}{l}\text { \& } \\
\text { d. }\end{array}$ & 多 \\
\hline 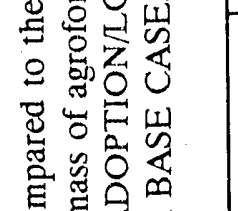 & 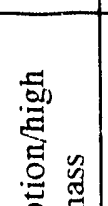 & 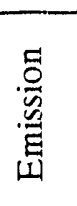 & $\begin{array}{l}\mathrm{y} \\
\mathrm{g}\end{array}$ & $\begin{array}{l}\vec{a} \\
\text { aे }\end{array}$ & $\begin{array}{l}\infty \\
\infty \\
\end{array}$ & $\begin{array}{l}0 \\
\vec{\sim}\end{array}$ & $\stackrel{\sim}{\sim}$ & $\stackrel{9}{\wedge}$ & $\overrightarrow{3}$ & ֻี \\
\hline 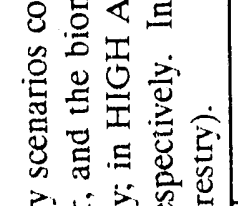 & 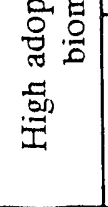 & 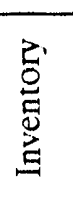 & $\begin{array}{c}\text { Dे } \\
\text { in }\end{array}$ & $\begin{array}{l}\text { \& } \\
\text { 点 }\end{array}$ & 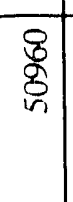 & $\begin{array}{l}0 \\
8 \\
0 \\
6\end{array}$ & $\begin{array}{l}0 \\
0 \\
0 \\
0\end{array}$ & $\begin{array}{l}\text { : } \\
0 \\
0\end{array}$ & $\begin{array}{l}0 \\
0 \\
0 \\
0 \\
0 \\
0\end{array}$ & $\begin{array}{l}0 \\
\text { ồ } \\
n\end{array}$ \\
\hline 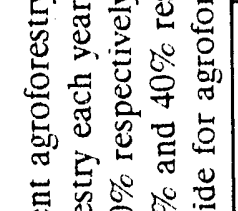 & 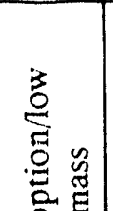 & 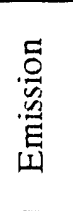 & $\overrightarrow{9}$ & $\begin{array}{l}n \\
\dot{8}\end{array}$ & $\begin{array}{l}+ \\
\dot{0}\end{array}$ & $\begin{array}{c}T \\
\dot{D}\end{array}$ & $\begin{array}{c}m \\
\infty\end{array}$ & $\begin{array}{l}\bar{j} \\
\infty\end{array}$ & $\begin{array}{l}\overrightarrow{0} \\
\vec{n}\end{array}$ & iे \\
\hline 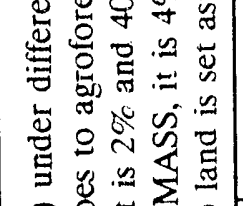 & 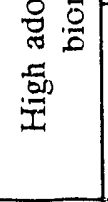 & 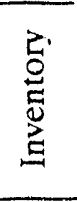 & $\begin{array}{l}0 \\
0 \\
8 \\
0 \\
n\end{array}$ & $\begin{array}{l}0 \\
8 \\
8 \\
0\end{array}$ & 客 & 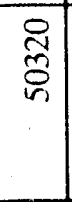 & $\begin{array}{l}0 \\
0 \\
0 \\
0\end{array}$ & $\begin{array}{l} \\
8 \\
8 \\
\end{array}$ & 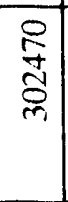 & 勇 \\
\hline 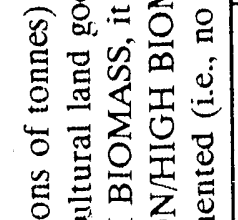 & 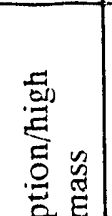 & 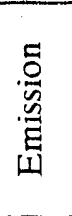 & $\begin{array}{c}2 \\
\stackrel{2}{\infty}\end{array}$ & $\begin{array}{c}\dot{D} \\
\infty\end{array}$ & $\stackrel{2}{\stackrel{2}{R}}$ & $\stackrel{\sim}{i}$ & : & $\frac{m}{b}$ & 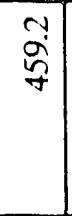 & 8 \\
\hline 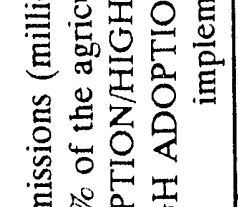 & $\begin{array}{l}0 \\
\text { 离. } \\
3 \\
3 \\
3\end{array}$ & 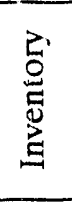 & $\begin{array}{l}0 \\
0 \\
0 \\
0\end{array}$ & \begin{tabular}{|l|}
0 \\
8 \\
0 \\
$n$
\end{tabular} & 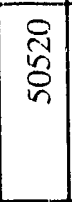 & 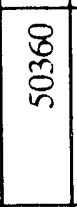 & \begin{tabular}{|l|} 
ते \\
ñ
\end{tabular} & $\begin{array}{l}0 \\
0 \\
8 \\
n \\
n\end{array}$ & 온 & 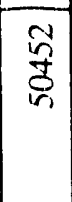 \\
\hline 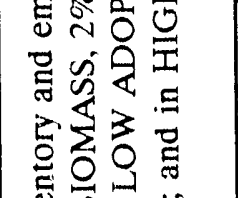 & 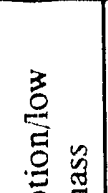 & 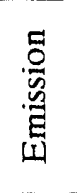 & $\begin{array}{l}n \\
\tilde{J} \\
\tilde{J}\end{array}$ & $\begin{array}{l}\infty \\
\vec{\Xi}\end{array}$ & $\begin{array}{c}a \\
\mathfrak{b} \\
z\end{array}$ & 宊 & $\overrightarrow{8}$ & \begin{tabular}{|c|}
$\vec{j}$ \\
$\stackrel{d}{j}$
\end{tabular} & $\begin{array}{l}\overrightarrow{3} \\
0 \\
0\end{array}$ & $\underset{I}{I}$ \\
\hline 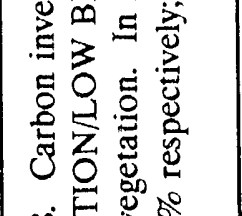 & $\begin{array}{l}0.5 \\
0 \\
0 \\
3 \\
3 \\
3\end{array}$ & 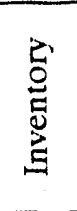 & $\begin{array}{l}0 \\
0 \\
5 \\
n\end{array}$ & 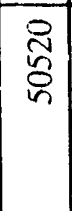 & 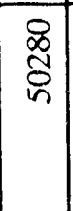 & $\begin{array}{l}0 \\
0 \\
8 \\
n \\
n\end{array}$ & \begin{tabular}{|c|}
0 \\
0.0 \\
$g$ \\
$g$
\end{tabular} & 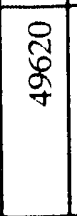 & \begin{tabular}{|l|}
$?$ \\
0 \\
0 \\
0 \\
\end{tabular} & $\begin{array}{l}\infty \\
\stackrel{\infty}{0} \\
0\end{array}$ \\
\hline 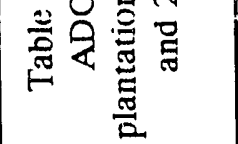 & & 5 & $\vec{\sigma}$ & g & gू & 就 & 次 & $\overrightarrow{8}$ & $\mid$\begin{tabular}{l|}
0 \\
0
\end{tabular} & $\frac{\overline{8}}{\Sigma}$ \\
\hline
\end{tabular}


are assumed to be between $\$ 50$ to $\$ 150$. This estimate is based on a planting density of 1,000 secdlings per hectare and a rajge in seedling costs (including distribution and extension costs) of $\$ 0.05$ to $\$ 0.15$ each. Arriy expenses incurred after tree establishment (e.g., weed control and other cultural managenantivities) are assumed to be borne by the individual farmer.

For the 2 and $4 \%$ annual adoption scenarios there would be approximately 26.2 and 47.3 million hectaies of land in agroforestry, respectively. Based on the $\$ 50$ to $\$ 150 /$ ha establishment costs and assuming a $10 \%$ real discount rate, total investment costs for the low adoption scenario (26.2 million hectares) would lie between $\$ 1310$ and $\$ 3930$ miilion and between $\$ 2360$ and $\$ 7090$ million for the high adoption seenario (47.3 million hectares). Agroforestry has the potential to reduce emissions by 38 million tonnes each year (low adoption with low biomass) to over 130 million tonnes each year (high adoption with high biomass), relative to the base case scenario or current enissions (Table 18). Costs per tonne of earbon sequestered would therefore range from a low of about $\$ 2$ under high biomass to $\$ 10$ under low biomass for both the low and high adoption seenarios.

\subsubsection{Industrial Reforestation}

African countries gencrate approximately $\$ 1$ billion (U.S.) each year in export carnings from forest products. However, these earnings are more than offset by approximately $\$ 2$ billion each year in imports, primarily pulp/paper and some wood products. ${ }^{43}$ In SubSaharan Africa, theic ate only ten countries that have net exports of forest products in excess of $\$ 1$ million annually. ${ }^{44}$ For tropical hardwood logs, the Ivory Coast, Ghana, and Nigeria have just about reached the limit of their production potential because of previous overcutting and forest management neglect (Ewing and Chalk 1988). Although there is considerable potential to increase production from Gabon, Congo, Liberia, Mozambique, Equatorial Guinea, and Zaire, there remains a critical need to improve forest management practices and to reforest logged-over areas to sustain exports and to limit the growth in imports. ${ }^{45}$

\footnotetext{
${ }^{43}$ The consumption of paper and paperboard in Sub-Saharan Africa has increased by $50 \%$ or by 0.3 million tonnes between 1970 and 1980 . The main factors for this increase are population growth, higher income levels, and higher literacy rates. Virtually all of the SubSaharan countries are importers of pulp and paper; however, these developing countries are becoming more self-sufficient in paper and paperboard production, increasing from $30 \%$ in 1970 to meeting $38 \%$ of their requirements in 1980 (Lintu 1984). However, Lintu (1984) notes that the developing countries will have a low rate of self-sufficierncy in the nonprinting and writing papers and in paperboard because production processes require large integrated mills to be efficient in production and these products require relatively long-fiber feedstocks that are not typically found in tropical forests.
}

${ }^{44}$ These countries in order of net export trade value are lvory Coast, Gabon, Cameroon, Swaziland, Congo, Liberia, Ghana, Central African Republic, Zaire, and Mozambique.

${ }^{45}$ Ewing and Chalk (1988) report that annual output of tropical logs from Africa will increase by about 4 million cubic meters by the year 2000. Current industry removals for the enitiic contincnt are approximately 54 mi!lion cubic meters. 
In Alrica, there are approximately 161 million hectares of commercial forests. The vast majority of this area (156 million hectares) is classified as natural broadleafed forest, with an additional 1 million hectares each of natural coniferous and bamboo forest. These forests aie the source of $96 \%$ of all log production. Industrial plantations account for less than $2 \%$ of eommercial forest area. Excluding South Africa, there are about 1.8 million hectares of industrial forest split equally between coniferous and broadlealed trees in Sub-Saharan Africa. Ewing and Chalk (1988) assert that these plantations have the capacity to produce 20 million cubic meters of wood annually, assuming an average growth of $12 \mathrm{~m}^{3} / y e a r$. Current annual growth from these plantations is about $3 \mathrm{~m}^{3} / y c a r$.

Three seenarios are examined under industrial reforestation. The first corresponds to the Tropical Forestry Action Plan (TFAP) agenda for tropical industrial reforestation (FAO 1987). The TFAP industrial reforestation recommendations are based on an analysis of supply and demand for industrial roundwood and the specific needs of developing countries.

Moreover, eurrent forest land use and obstacles to improved management were reviewed in each country to develop specilic annual reforestation strategies. They identified seven countries for industrial reforestation: Cameroon - 50()) ha/ycar for a total of 25()(N); Congo -

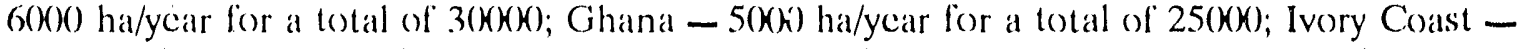
$25(\%)$ ha/year for a total of 125(K)(); Liberia - 3(K) ha/year for a total of 150(K); Nigeria $50(0)$ ha/year for a total of $25(\%)()$, and Uganda - 50)( ha/year for a total of $250 \%)$. Over the 5-year plan, a total of 495(k) hectares is targeted for reforestation. Because the 1991 to 2001 time period is of interest, these annual planting levels will be maintained over a 10-year period, resulting in a total of $99(k)())$ planted hectares.

The second secnario is based on the conversion of an annual pereentage of high-and medium-productivity nonforest land to forest. ${ }^{46}$ The rate of conversion is based on annual deforestation rates and WRI/IIED (1988) estimates of total industrial roundwood removals. The specific reforcstation amount is the product of industrial roundwood production to total wood production (fuelwood and industrial) and the annual rate of deforestation (hectares per year). In effect, this scenario assumes that industrial roundwood removals are offset by reforestation. ${ }^{47}$ This specific option may rovide an upper limit on what could be expected from industrial reforestation. ${ }^{48}$

\footnotetext{
"46 Industrial reforestation could be carried out by the logger who would be charged with the responsibility of planting trees. Typically, governments collect reforestation fees on timber production and use their own forestry departments to carry out the planting. In many cases, reforestation fees are not used for such purposics.

${ }^{47}$ Plantations could consist of plantings of valuable hardwoods trees or coniferous (longfiber) trees appropriate for meeting future domestic pulp and paper needs.

${ }^{48}$ In areas where there has been extensive logging, forests could be poorly stocked, not well maintained, or otherwise improperly managed. Improved management practices on these degraded forests could increase forest growth and lessen the impact on natural forests. Moreover, reducing saw-milling wastes and developing uses for secondary species could also lessen the impact on natural forests. These options, however, are not specifically address $\mathrm{d}$ in this study.
} 
The third secnario uses the base-case model to determine the total amount of land that is physically suitable for forest plantations and then assumes that $0.1 \%$ of that land would be planted annually. Suitability was defined as land that had a potential productivity of greater than 6 tonnes C/ha/year and is not in "forest" or "forest-fallow" land use. This scenario was then modified to include land with potential productivity greater than 4 tonnes $\mathrm{C} / \mathrm{ha} / \mathrm{year}$.

The average amount of carbon that could be stored by each plantation hectare over a rotation was assumed to be half the amount of carbon that would be stored just prior to harvest. The amount stored at harvest was assumed to be 120 tonnes/ha for plantations on sites whose potential productivity was greater than 8 tonnes/ha/year (high site class), 100) tonnes/ha for plantations on sites with potential productivities between 8 and 6 tonnes/ha/year (moderate site class), and 90 tonnes/ha for plantations on sites with potential productivities between 4 and 6 tonnes C/ha/year (low but feasible site class). As with the agroforestry option, carbon storage accrued the year of establishment. Thereafter, the plantation carbon inventory remained consiant, and additional carbon is sequestered only after new plantations are established.

To calculate the amount of carbon that would be stored under each of the scenarios, the land area that would be biologically suitable for plantation forestry (i.e., land use $=$ nonforest and potential productivity $>4$ tonnes C/ha/year) was first determined. Suitable land was further ciivided into the three siic classes - high, moderate, and low. The relative amounts of high, moderate, and low site class plantation land in each zone were multiplied by their respective carbon storage potential to determine the average amount of carbon that could be stored in a hectare of plantation in a particular zone. This average amount per hectare was then multiplied by the number of hectares of plantations to determine the carbon that would be sequestered through plantations. The carbon sequestered under each scenario was then compared to average carbon emissions predicted from the base case.

Table 19 gives the land area currently not in forest or forest -fallow agriculture area that is biologically suitable for plantations. The total amount of land in cach country that is "biologically suitable" is, of course, an overestimate of the real land base available for plantation forestry, as the value includes land already in agriculture or urban land use. However, the distribution of the land and the relative magnitude of land area in different countrics does indicate where plantation forestry might have the most biological potential. Cameroon, Congo, Gabon, Guinea, Liberia, Nigeria, and Zaire contain large areas of land with high potential for plantations. Several countries, as noted in Table 19, have no suitable land according to the above biological criteria. Because the sarupling strategy used to develop the model data base was regular and fairly wide-spaced, the land area available in small countries may have been underestimated, particularly if it was concentrated in one particular section of the country.

The costs for establishing plantations are dependent on many site-specific factors, such as the previous land use, extent of site preparation, availability of seedlings, silvicultural management, and protection. Leach and Gowen (1987) report establishment costs ranging from a low of $\$ 200 /$ ha to $\$ 2000 /$ ha. Although it is difficult to generalize, higher costs tend to be associated with more arid and less favorable growing conditions. In addition to establishment, there will be annual costs for maintenance (e.g., weed control), protection, and management. Plantation establishment costs for this study were therefore assumed to range 


\begin{tabular}{|c|c|c|c|c|}
\hline \multicolumn{5}{|c|}{$\begin{array}{l}\text { Table 19. Arca of nonforest land in the three plantation sultabillty classes by country and } \\
\text { zonc. Botswana, Gambia, Guinea Bissiu, Namibla, Nlger, and Somalla were not predicted to have } \\
\text { land sultable for plantations. }\end{array}$} \\
\hline \multirow[b]{2}{*}{ Country } & \multirow[b]{2}{*}{ Tone } & \multicolumn{3}{|c|}{ Arca $\left(10^{6}\right.$ ha $)$} \\
\hline & & Low & Medium & lligh \\
\hline Angola & $\begin{array}{l}1 \\
2 \\
3\end{array}$ & $\begin{array}{l}0.02 \\
3.02 \\
0.62\end{array}$ & 2.31 & - \\
\hline Benin & 1 & 1.39 & 0.01 & - \\
\hline Burkina lasoo & $\begin{array}{l}1 \\
2 \\
\end{array}$ & $\begin{array}{l}2.41 \\
0.01 \\
\end{array}$ & $\begin{array}{l}0.24 \\
. \\
\end{array}$ &. \\
\hline Burundi & 1 & - & 0.36 & - \\
\hline Cameroxon & $\begin{array}{l}1 \\
2 \\
3\end{array}$ & $\begin{array}{l}1.33 \\
5.34 \\
0.42\end{array}$ & $\begin{array}{l}0.24 \\
0.91 \\
- \\
\end{array}$ & $\begin{array}{l}1.21 \\
2.112 \\
- \\
\end{array}$ \\
\hline Central Aerican Rep. & $\begin{array}{l}1 \\
2 \\
\end{array}$ & $\begin{array}{l}0.21 \\
6.49 \\
\end{array}$ & 0.81 & . \\
\hline Chad & $\begin{array}{l}1 \\
2 \\
3 \\
\end{array}$ & 2.88 & $\begin{array}{l}1.84 \\
-\end{array}$ & - \\
\hline (ongo) & $\begin{array}{l}1 \\
2 \\
3 \\
\end{array}$ & $\begin{array}{l}1.8 .3 \\
0.42 \\
4.81 \\
\end{array}$ & $\begin{array}{l}- \\
1.02 \\
0.47 \\
\end{array}$ & $\begin{array}{l}0.04 \\
- \\
- \\
\end{array}$ \\
\hline liquatorial (suinea & 1 & - & 0.35 & - \\
\hline Itthiopia & $\begin{array}{l}1 \\
2 \\
\end{array}$ & $\begin{array}{l}2.51 \\
0.64\end{array}$ & $\begin{array}{l}9.35 \\
0.21 \\
\end{array}$ & $\begin{array}{l}1.53 \\
-\end{array}$ \\
\hline Gabon & $\begin{array}{l}1 \\
2 \\
\end{array}$ & $\begin{array}{l}1.35 \\
- \\
\end{array}$ & $\begin{array}{l}0.66 \\
- \\
\end{array}$ & $\begin{array}{l}1.34 \\
- \\
\end{array}$ \\
\hline Ghana & $\begin{array}{l}1 \\
2 \\
3 \\
\end{array}$ & $\begin{array}{r}0.24 \\
3.41 \\
<0.01 \\
\end{array}$ & $\begin{array}{c}<0.01 \\
\cdot \\
\end{array}$ & - \\
\hline Guinca & $\begin{array}{l}1 \\
2 \\
\end{array}$ & $\begin{array}{l}0.29 \\
4.57 \\
\end{array}$ & 1.87 & 0.21 \\
\hline Ivory Coast & $\begin{array}{l}1 \\
2 \\
\end{array}$ & $\begin{array}{l}0.97 \\
- \\
\end{array}$ & 0.95 & $\begin{array}{c}0.0 .3 \\
- \\
\end{array}$ \\
\hline Kenya & $\begin{array}{l}1 \\
2 \\
\end{array}$ & $\begin{array}{l}1.77 \\
- \\
\end{array}$ & $\begin{array}{l}1.08 \\
- \\
\end{array}$ & $\begin{array}{l}0.21 \\
- \\
\end{array}$ \\
\hline Liberia & 1 & 0.35 & $1 . \hat{2} 1$ & 0.66 \\
\hline Madagascar & $\begin{array}{l}1 \\
2 \\
3 \\
\end{array}$ & $\begin{array}{r}2.38 \\
11.77 \\
- \\
\end{array}$ & $\begin{array}{l}1.24 \\
3.39 \\
- \\
\end{array}$ & $\begin{array}{l}0.35 \\
4.12 \\
-\quad \\
\end{array}$ \\
\hline Malawi & 1 & 1.08 & 0.23 & - \\
\hline
\end{tabular}




\begin{tabular}{|c|c|c|c|c|}
\hline \multicolumn{5}{|c|}{$\begin{array}{l}\text { 'Table 19. Area of nonforest land in the three plantation sultability classes by country and } \\
\text { zonc. Botswana, Gambla, Guinea Blssau, Namibla, Niger, and Somalla were not predicted to have } \\
\text { land sultable for plantations. }\end{array}$} \\
\hline \multirow[b]{2}{*}{ Country } & \multirow[b]{2}{*}{ Zone } & \multicolumn{3}{|c|}{$\operatorname{Arca}\left(10^{6}\right.$ ha $)$} \\
\hline & & Low & Medlum & High \\
\hline Mall & $\begin{array}{l}1 \\
2 \\
3\end{array}$ & 3.14 & 1.83 & $\begin{array}{l}0.30) \\
-\end{array}$ \\
\hline Mozambique & $\begin{array}{l}1 \\
2 \\
3\end{array}$ & $\begin{array}{r}12.67 \\
0.02 \\
- \\
\end{array}$ & $\begin{array}{lll}0.24 \\
- \\
\end{array}$ & 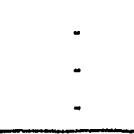 \\
\hline Nigeria & $\begin{array}{l}1 \\
2 \\
3\end{array}$ & $\begin{array}{r}2.18 \\
11.07 \\
4.68\end{array}$ & $\begin{array}{l}0.44 \\
2.6 .3 \\
-\end{array}$ & $\begin{array}{l}1.60 \\
0.06 \\
-\end{array}$ \\
\hline Rwanda & & 1.52 & - & - \\
\hline Senegal & & $\therefore$ & 0.29 & - \\
\hline Sudan & & $\begin{array}{l}0.92 \\
2.97\end{array}$ & - &. \\
\hline Sierra leone & & - & 0.90 & $<0.01$ \\
\hline Tanzania & $\begin{array}{l}1 \\
2 \\
3 \\
\end{array}$ & $\begin{array}{l}0.35 \\
4.54 \\
2.24 \\
\end{array}$ & $\begin{array}{l}1.75 \\
1.73 \\
0.79\end{array}$ & $\begin{array}{l}- \\
0.42 \\
-\end{array}$ \\
\hline Togo & 1 & 1.35 & 0.43 & - \\
\hline Uganda & & $\begin{array}{l}0.42 \\
1.12 \\
\end{array}$ & $\begin{array}{l}0.42 \\
0.19 \\
\end{array}$ & $\therefore$ \\
\hline Tairc & $\begin{array}{l}1 \\
2 \\
\end{array}$ & $\begin{array}{r}3.59 \\
10.43 \\
\end{array}$ & $\begin{array}{l}0.98 \\
4.07 \\
\end{array}$ & $\begin{array}{l}0.65 \\
1.96 \\
\end{array}$ \\
\hline Tambia & $\begin{array}{l}1 \\
2 \\
\end{array}$ & $\begin{array}{l}0.97 \\
1.93 \\
\end{array}$ & $\begin{array}{l}0.52 \\
.\end{array}$ & - \\
\hline Zimbabwe & & $\begin{array}{l}0.23 \\
- \\
\end{array}$ & - & - \\
\hline Toxal & & 128.64 & 45.96 & 16.71 \\
\hline
\end{tabular}


between $\$ 250$ and $\$ 750 /$ ha with annual recurring cests of $\$ 50$ ha/year. Total lile-cycle eosts for plantation establishment with recurring maintenance over the 1991-2001 period would therefore lic between $\$ 560$ and $\$ 1060 /$ ha, assuming a $10 \%$ real discount rate.

The carbon that might be stored annually in plantations is shown for each of the three plantation secnarios and the base-case in 'Table 20. The amount of land it would take to realize these carbon storages for each if the three plantation seenartos is summarized in Table 21. The amount of land that would be planted each year for each of the seenarios ranges from 62,700) to $377,6(0)$ hectares. The total costs of establishing and maintaining plantations from a low of $\$ 350$ to $\$ 660$ million for the lowest planting secnario (land with a productivity greater than 6 lonnes ha/year) to a high of $\$ 2110$ to $\$ 4(0)$ million for the most aggressive plantation secnario (offiset of industrial wood removals). 'The cost of sequestering carbon for each of these scenarios is about $\$ 11$ to $\$ 22 /$ tonne.

\subsubsection{Comparison of Land-Use Options}

When the savings in carbon are compared for the most ambitious scenario under each of the three management strategies to the base-case mean emission of 152 million tonnes/ycar between 1991 and 20(1)1, preservation (with no deforestation and with recovery of degraded vegetation) results in net secpuestering of 62.5 million tonnes $\mathrm{C} / \mathrm{year}$ (a reduction in emissions from 152 lo -62.5 million tonnes); agroforestry (high adoption/high biomass secnario) reduces cmissions to 20.2 million tonnes C/year; and plantations reduce emissions to 134 million tonnes $\mathrm{C} / y c a r$. In lotal, the combination of these three land-use management options whuld reduce emissions from 152 to a net average annual sequestering of 212 million tonnes. ${ }^{49}$ The total change in carbon would be approximately 36.3 million tonnes.

Scenarios involving lower amounts of land would be considerably more tractable to implement; however, the amount of carbon sequestered would also be less. Consider the combined option of reducing current deforestation rates by $50 \%$, converting $2 \%$ of agricultural land to agroforestry, and establishing approximately $99,(6)($ ) hectares each year for industrial forestry. This combined option would involve preserving 15 million hectares, converting 11 million hectares 10 agroforestry, and establishing approximately 1 million hectares of new forest lands by the end of $2(0) 1$. The amount of carbon involved with this combinced option would lic between 110 and 150 million tonnes each year with annual costs of $\$ 360$ to $\$ 920$ million, exclusive of any costs associated with institutional, socioceonomic, and political constraints.

In comparing among the three land use options, agroforestry has the lowest per tonne carbon cost $(\$ 2$ to $\$ 10)$. The lower carbon sequestering cost associated with agroforestry is because governments are only responsible for the start-up costs (c.g., seedlings) and do not bear the opportunity costs for land or the anr.dal costs for tending. These latter costs are borne by the landholder. The carbon costs for the industrial reforestation option (\$11 to \$22) are higliest among the three options. However, the costs for reforestation could be offect or

\footnotetext{
4h This study did not specifically address approaches for increasing the productivity of natural forests and improved methods of forest regeneration.
} 


\begin{tabular}{|c|c|c|c|c|}
\hline \multirow[b]{2}{*}{ Countity } & \multicolumn{2}{|c|}{$\begin{array}{c}0.1 \% \text { of all nonforest land with productivily } \\
\text { gresiter than: }\end{array}$} & \multirow[b]{2}{*}{ "VlAA" } & \multirow{2}{*}{$\begin{array}{l}\text { Offsel of lindustrinl } \\
\text { removils }\end{array}$} \\
\hline & 4 lommes/han/yr & 6 tonnes/lin/yr & & \\
\hline Angolli & 0.28 & 0.12 & 0,00 & 0.74 \\
\hline Benin & 0.07 & $0,(6)$ & 0,00 & 0.15 \\
\hline Hurkinn liaso & 0,12 & $0,0 !$ & $0 .(0)$ & $0 .(x)$ \\
\hline Burundi & 0.02 & 0,02 & $0,(60)$ & $0,(0)$ \\
\hline Camercon & 0.57 & 0.25 & 0.25 & 1.26 \\
\hline Central African Rep. & 0.34 & 0.04 & $0.04)$ & 0.3 .3 \\
\hline Clind & 0.22 & $0 .(69$ & 0.00 & $0 .(6)$ \\
\hline Congro) & 0.40 & 0,08 & 0.28 & 0.36 \\
\hline licpuitorinl Ciulnen & 0.102 & 0.12 & 0.00 & 0.04 \\
\hline lithlopla & 0.71 & 0.57 & $0 .(\mathrm{K})$ & 0.22 \\
\hline Cinlx)\| & 0.18 & 0.12 & 0.09 & 0.29 \\
\hline Cihnnn & 0.17 & 0.00 & 0.23 & $0 .(x)$ \\
\hline Cilinen & 0.33 & 0.11 & $0 .(\mathrm{K})$ & 0.56 \\
\hline Ivory Coast & 0.10 & 0.05 & 1.19 & 8.25 \\
\hline Kenyin & 0.15 & 0.07 & $0,(k)$ & 0.10 \\
\hline Litheria & 0.12 & 0.10 & 0.16 & $0.2 \%$ \\
\hline Madragnscar & 1.14 & 0.50 & 0.00 & 0.92 \\
\hline Mallawi & 0.06 & 0,01 & $0 .,(K)$ & 0,35 \\
\hline Mill & 0.25 & 0,11 & 0.00 & $0 .(k)$ \\
\hline Mozambicule & 0.50 & 0.01 & 0.00 & 0.33 \\
\hline Nigeria & 1.06 & 0.26 & 2.34 & 1.50 \\
\hline Rwanlia & 0.07 & $0 .(0)$ & $0 .(1)$ & $0 .(k)$ \\
\hline Senlegill & 0,02 & 0.02 & 0.00 & $0 .(6)$ \\
\hline Suclan & 0.18 & 0.00 & 0,00 & $0 .(6)$ \\
\hline Sierrn leone & 0.05 & 0.05 & 0.00 & 0.01 \\
\hline T'anzanla & 0.56 & 0.24 & $0 .(0)$ & 0.37 \\
\hline I'ogo & $0 \% 3$ & 0.02 & 0.00 & 0.12 \\
\hline Uganda & 0.10 & 0.03 & 0.2 .3 & 0.30 \\
\hline Zaire & 1.04 & 0.41 & 0.00 & 1.34 \\
\hline Zambia & 0.16 & 0.03 & 0.00 & 0.19 \\
\hline Zimbatiwe & 0,02 & 0.00 & 0.00 & 0.00 \\
\hline TOTAL. & 9.11 & 3.30 & 4.67 & 18,00 \\
\hline
\end{tabular}

"Tropical Forestry Action Plan. 


\begin{tabular}{|c|c|c|c|c|}
\hline \multirow[b]{2}{*}{ Country } & \multicolumn{2}{|c|}{$\begin{array}{l}0.1 \% \text { of all nonforest land with } \\
\text { prestuctivity grenter tham: }\end{array}$} & \multirow[b]{2}{*}{ "WAN" } & \multirow{2}{*}{$\begin{array}{l}\text { colised ol } \\
\text { fincluslefinl } \\
\text { removinls }\end{array}$} \\
\hline & 4 lonnes//1u/yr & o lonnes $\cdot 1$ yr. & & \\
\hline Angola & 5,98 & 2.31 & $\therefore$ & 16,8 \\
\hline Benln & 1.40 & 0,01 & - & 3.3 \\
\hline Burklnu linso. & 2.66 & 0.24 & . & 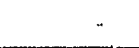 \\
\hline Burrundi & 0.36 & 0.36 & $\therefore$ & $<0.1$ \\
\hline Cameroon & 11.47 & 4.38 & 5.0 & 25.3 \\
\hline Centrul African Rep. & 7.51 & 0.81 & - & 7.2 \\
\hline Chand & 4.72 & 1.84 & $\therefore$ & . \\
\hline Congo & 8.59 & 1.53 & 6.0 & 7.7 \\
\hline liqullontal ciminea & 0.35 & 0.3 .5 & . & 0.7 \\
\hline Itilicplin & 14.24 & 11.09 & . & 4.4 \\
\hline Cintron & 3.3 .5 & $1,(\mu)$ & . & 5.6 \\
\hline CHama & 3,42 & $0 .(K)$ & 5.0 & - \\
\hline Clubuea & 6.97 & 2.11 & - & 12,0 \\
\hline Ivory Const & 0.58 & 0.988 & 25.0 & 173.0 \\
\hline Kenyn & $.3 .(K)$ & 1.29 & $\therefore$ & 2.0 \\
\hline 1.llerin & 2.22 & 1.87 & 3,0 & 5.5 \\
\hline Madagniscall & 27.25 & 9.10 & - & 18.7 \\
\hline Malawl & 1.31 & 0.2 .3 & $\therefore$ & 7.5 \\
\hline Mulli & 5.27 & 2.13 & - & . \\
\hline Mozambique & 12.93 & 0.24 & $\dot{-}$ & 7.2 \\
\hline Nigeria & 22.67 & 4.74 & 50.0 & 33,0 \\
\hline Rwanda & 1.52 & $0,(K)$ & - & - \\
\hline Senegil & 0.73 & 0.29 & - & - \\
\hline Sierra leone & $0 . \mathcal{M})$ & $0 .(\mathcal{X})$ & - & $\therefore$ \\
\hline Sudan & 3,89 & 0.0() & . & 0.1 \\
\hline T'anzania & 11,82 & 4.69 & $\therefore$ & 7.8 \\
\hline I'ogo & 1.78 & 0.43 & - & 2.5 \\
\hline Uganda & 2.15 & 0.61 & 5.0 & 6.5 \\
\hline Zaire & 21.68 & 7.66 & - & 27.8 \\
\hline Zambia & 3.42 & 0.52 & 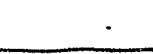 & 4.0 \\
\hline Rimbahwe & 0.23 & 0.00 & - & - \\
\hline TOTALI & $1 \% 6,43$ & 62.70 & 94.0 & .371 .1 \\
\hline
\end{tabular}

ar'ropical fiorestiy Action Plan. 
lowered il governments revised conecssion agreements and opteci lor collection of specifie reforestation fees as part of royalty payments.

\subsection{REMO'TE SENSING RESUL'IS}

\subsubsection{Comparison of AVIIRR Interpretation of Forest and Savanna (Open Land) of Central Africa and FAO Vegetation Map}

LAC AVHRR imagery of contral Alrica $\left(8^{\circ} \mathrm{E}\right.$ to $32^{\circ} \mathrm{E}, 7^{\circ} \mathrm{N}$ to $\left.8^{\circ} \mathrm{S}\right)$ for 1988 wals chassiffed into three land cover dasses: elosed forest, mixed forest/savanna, and savanna. ${ }^{50}$ Clesed forest has a cool spectral signature due to the cooling effect of forest evapotranspiration, while savanna (and grassland) has a warmor spectral signature. This difierence wats used to separate forest from savanna in the imagery. The classified imagery was georegistered using dominate: landscape fealures such as coastline and river bends. Accuracy of the georegistration was hampered by the lack of good topographic maps of this region.

The elassified georegistered AVHRR image was then sampled for land eover type at each of the point locations that were used to sample the FAO vegetation map used in the land-use model. Both the value of the pixel within which the point fell and the median value of a 5 by 5 box of pixels surrounding the point eenter were extracted from the AVHRR. (Later analysis showed that, out of 1875 sampling locations, the exact pixel value and the median pixel value varied in only 2 instances. Thus possible error due to slight geographic misregistration of the AVHRR imagery should not affect the interpretation.)

The 21 FAO vegetation classes that occurred at points located w'thin this region were grouped into 3 land-cover classes analogous to those of the AVHRR clissilication. Table 22 shows how the original FAO vegetation classes were partitioned among the thee broad land cover classes: forest, mixed forest/savanna and savanna.

The AVHRR land-cover value (single pixel value) and the FAO grouped land-eover value were compared at each point. Table 23 shows the eorrespondence between the grouped FAO land-eover values and the AVHRR land-cover values. In general, the classifications corresponded with each other. The AVHRR classification suggested that there was less colosed forest in the region than indicaled in the FAO vegetation map. As expected, most of the pixels classified as forest in the AVHRR clissification were also classified as forest in the FAO classificalion. Likewise, savanna pixels tended to be the same in both classilicaltions. The pixels classified as "mixed" by the AVHRP analysis were generally classified as forest on the FAO map, while the pirels classified as "mixed" by the FAO map were generally classified as savanna by the AVHRR map. If the AVHRR classification is taken as "true," then one must conclude that there is less forest in eentral Africa than the FAO map would indicate.

${ }^{50}$ LAC AVHRR imagery is collected daily by NOAA weather satellites. The resolution of the imagery is $1.1 \mathrm{~km}^{2}$. The imagery was classified using thermal band 3 and thresholding the band values. Because band values are a continuum, the selection of particular threshold band values to delineate each land-cover class is somewhat arbitrary. 


\begin{tabular}{||c|l|l||}
\hline \multicolumn{2}{||c||}{ Table 22. Grouping of FAO vegetation classes occurring in central Africa into three land } \\
cover classes
\end{tabular}


Table 23. Correspondence matrix of AVHRR class values and FAO class values. The values within the matrix are the percentage of the number of points analyzed-in this case, 1868 points. For example, $44.06 \%$ of the points were classified as forest in both the AVHRR analysis and the FAO vegetation map, whereas $5.84 \%$ of the points were classified as forest by the FAO map and savanna by the AVHRR analysis. Also, $60.01 \%$ of the points were classified as forest with with the FAO map, whereas $48.13 \%$ were classified as forest by the AVHRR analysis.

\begin{tabular}{||l|r|r|r|r||}
\hline \multirow{2}{*}{ FAO class } & \multicolumn{4}{|c|}{ AVHRR class } \\
\cline { 2 - 5 } & \multicolumn{1}{|c|}{ Forest } & \multicolumn{1}{c|}{ Mixed } & \multicolumn{1}{c|}{ Savanna } & FAO Total \\
\hline Forest & 44.06 & 10.12 & 5.84 & 60.01 \\
\hline Mixed & 00.74 & 2.78 & 8.67 & 12.21 \\
\hline Savanna & 3.32 & 4.12 & 20.34 & 27.78 \\
\hline AVHRR Total & 48.13 & 17.02 & 34.85 & \\
\hline
\end{tabular}


To examine the pattern and location of the classification differences, the point landcover values were plotted by their latitude and longitude to create "maps" of land-cover class (Appendix 3). The northern boundaries of the closed forest from each "map" coincided fairly well, although the AVHRR map tended to place the boundary about $0.4^{\circ}$ further south. The southern boundaries did not coincide. Along the southern Atlantic coast, the AVHRR map tended to class the land cover "forest" while the FAO map classed the land cover "savanna." However, the AVHRR map tended to class all land south of the Kasai River between the towns of Bandundu and licbo as savanna, while the FAO map shows pockets of forest within the savanna. Since the FAO map was based in part on old information in this region (Zaire vegetation maps dating from 1939 were used in creating the FAO map), the difference between the up-to-date AVHRR map and the FAO map could be interpreted as a loss of forest cover. However, both of these conclusions are quite tenuous. There are undoubtedly errors in the AVHRR classification, and the point method of analysis (rather than directly overlaying the FAO map and the AVHRR classified image) could also induce errors. Furthermore, the FAO map might never have been representative of vegetation conditions in this part of Africa.

This remote sensing exercise tempered confidence in the accuracy of the FAO vegetation map in this region and consequently carbon inventory and emission predictions that were based on that map. The exercise also indicated locations within this region where further image and ground analysis are warranted.

\subsubsection{Landsat Analysis of Land-Cover Change in Central Africa}

Three sets of Landsat MSS imagery and one set of Landsat MSS/SPOT imagery were used to explore land-cover change in central Africa. The location of these images is shown in Fig. 16a. The dite and location of the images ate shown in Table 24. The sets of imagery were chosen on the basis of availability, nearness to the dense lorest-savanna/woodland border (as perceived from the 1988 AVHRR imagery), and evidence of fire activity in the area (again as perceived from the 1988 AVHRR imagery). Effort was focused on the border areas, on the premise that land-cover change was most likely to occur in the more accessible border forest. By examining different portions of this border, the spatial variability in change could be explored.

Use of the images clearly illustrated the difficulties associated with use of satellite data: cloud-free, haze-free imagery exists for only a limited portion of this region. Searching the Landsat Archives, fewer than 30 locations were found with overlapping clear images taken in the 1970s and the late 1980s during the same month (the requirements necessary for change detection). In other words, by itself existing fine-resolution satellite data are sufficient to quantify land-cover change on probably less than $5 \%$ of this land area. Including SPOT imagery taken in the late 1980 s does not improve the situation significantly. Nonetheless, satellite imagery represents the best and only source in many cases of information on deforestation. Extrapolating regional values of deforestation from these local estimates will be difficult, but methodologies are being developed for doing so (Singh 1989).

Of the four sites evaluated, the Central African Republic (C.A.R.) site received the most analysis. A quantitative assessment of landcover change was performed for this site; qualitative assessments were made of the other sites. The C.A.R site was selected for detailed 


\begin{tabular}{|c|c|c|}
\hline Date & Path/Row ${ }^{2}$ & Location \\
\hline $1 / 28 / 73$ & $196 / 57$ & Southwest C.A.R.-Carnot, Berberati, \\
\hline $1 / 17 / 87$ & $183 / 57$ & Amada Gaza, Gamboula. A small section of Cameroon \\
\hline $\begin{array}{l}7 / 6 / 73 \\
6 / 2 / 86\end{array}$ & $\begin{array}{l}193 / 62 \\
180 / 62\end{array}$ & $\begin{array}{l}\text { Center west Zaire-centered just SEof Kutu. Includes southern } \\
\text { part of Lac Mai-Ndombe. } 400 \mathrm{~km} \mathrm{NE} \text { of Kinshasa }\end{array}$ \\
\hline $\begin{array}{l}12 / 15 / 72 \\
1 / 12 / 87\end{array}$ & $\begin{array}{l}188 / 58 \\
116 / 344\end{array}$ & $\begin{array}{l}\text { NE corner of Zaire-W of Isiro and S of Bwendi (SPOT } \\
\text { imigery the second date). } 450 \mathrm{~km} \mathrm{~W} \text { of Uganda and } 300 \mathrm{~km} \\
\mathrm{~N} \text { of SE corner of C.A.R. }\end{array}$ \\
\hline $\begin{array}{l}1 / 13 / 76 \\
1 / 15 / 87\end{array}$ & $\begin{array}{l}187 / 58 \\
174 / 58\end{array}$ & $\begin{array}{l}\text { NE corner of Zaire-centered on Mungbere, just east of SPOT } \\
\text { site. } 300 \mathrm{~km} \mathrm{~W} \text { of Uganda and } 150 \mathrm{~km} \mathrm{~N} \text { of Sudan }\end{array}$ \\
\hline
\end{tabular}

${ }^{2}$ Path/row changed with between Landsats 1,2 , and 3 and Landsats 4 and 5 . Thus scenes taken in the 1970 s and early 1980 s with Landsats 1 , 2, or 3 do not perfectly overlay scenes taken in the late 1980 s by Landsats 4 or 5 nor are their path/row numbers the same. There is no correspondence between SPOT path and row numbers and Landsat path and row numbers. 

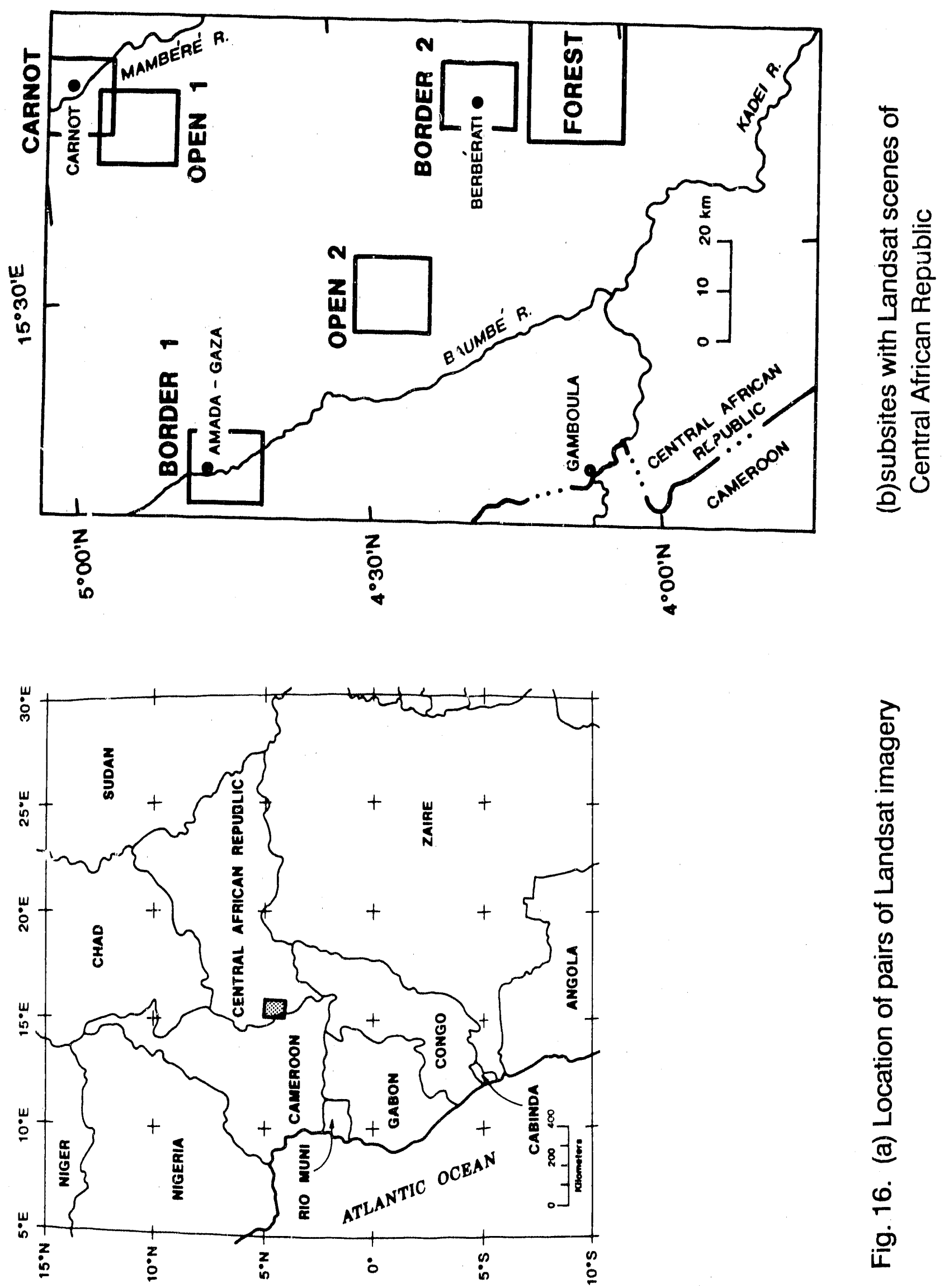

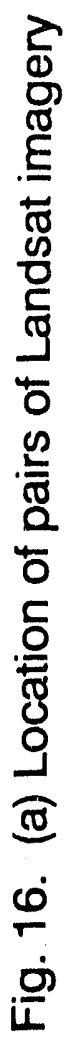


analysis as it is the only site for which there are topographic maps at a scale finer than 1:1,000,000). The two C.A.R secnes were classified into four land-cover classes-- forest (closed forest with the characteristic dark red spectral signature of tropical forest with emergent trees); degraded forest (spectrally similar to forest but brighter indicating more open and occurring where forest had been); edge (mixed forest-nonforest, occurring at the edge of forest patches) and nonforest (vegetated land but with little to no tree element). These classes were developed on the basis of reflectance characteristics and spatial relationships. Interpretation of the imagery was confounded in some instances because of smoke haze from savanna/grassland fires and from the differential effects of burning. A recently burned savanna may have a very different spectral signature from a savanna that was burned 3 months or a year before.

Six subsites within the C.A.R. scene were evaluated in detail (Fig. 16b). The original hope had been to evaluate the entire scene, but widespread fire haze in the 198 . scene, which was not apparent until analysis of the image had begun, precluded accurate full-seene analysis. Full-seene analysis is not such a problem with the Zaire images, which have more cloud cover but do not have widespread haze. The selected subsites were relatively haze/smoke free and typical of the larger seene. Three subsites contained a miajor city. Two subsites were away from cities in areas dominated by shrub savanna according to phytosociological maps of C.A.R.. The forest in these subsites is limited to riparian corridor forests. One subsite is in a completely forested area away from any major cities. The vegetation cover and forest transition statistics for each of the six subsites are given in Table 25 .

The C.A.R. results can be summarized as follows:

1. No change was seen within the large tracts $\left(>10 \%() \mathrm{km}^{2}\right)$ of intact forest: that is, destruction of the dense forest from within was not observed. This contrasts with the situation in Brazil, where the interior forest is being destroyed from within.

2. Riparian forests experienced significant losses. The edges of the forest were opened up and the canopies thinned.

3. Forests near urban eenters showed major changes. Typically only $50 \%$ of the forest present in 1973 appeared intact and "undisturbed" in 1987. However, complete loss of forest was uncommon ( $5 \%$ at most). Rather the forests appeared to have been opened up or partially harvested.

Given the lack of survey ground truth, these conclusions and their associated statistics must be regarded as preliminary. Although the images were interpreted with the aid of an individual who had been in the Carnot area recently, the forest changes were subtle and ground survey data are needed to verify the validity of the "edge and "degraded forest" classes. If the "edge" and "degraded forest" classes are correct then riparian forests and forests near urban areas have indeed undergone significant changes since 1973. If, however, the "edge and "degraded forest" classes are really more aligned with "forest" then none of the forests of the C.A.R seene have undergone much change. Ground survey data would also help quantify the loss of biomass associated with a "forest" to "degraded forest" or "edge" transition. 
The observations made at the C.A.R. site are applicable to the three Zaire sites. There is little or no evidence that interior forest is being converted on a large scale to agriculture or to more open woodland at any of the Zaire sites. Loss of forest eover is evident around the forest interior town of Munghere and along the highway that passes through the town. The elearing of the forest or opening up of the forest canopy along the major highway running east to west across northern Zaire is also apparent in the 1988 AVHRR imagery.

The Landsat analysis provides insight into the pattern and local rates of deforestation. It suggests that information on deforestation rates for specific forest types would improve the carbon emission model. This could be done but would complicate the model considerably. The imagery results support the low relative rate of deforestation used in the model for calculating carbon emissions from Zaire. This is significant because Zaire has the greatest potential for carbon emissions; thus, any inaccuracies with regard to Zaire's deforestation rates could influence the validity of the model results. 
Table 25. Vegetation cover and forest change statistics of six C.A.R. subsites. Forest change statistics area based on the 1973 area of forest. Degraded forest was not apparent as a spectral class in the 1973 seene thus it was not assessed.

A. Urban - Forest border (Amada Gaza) / Total area $=100755$ ha

\begin{tabular}{|l|r|r|r|r|}
\hline \multicolumn{1}{|c|}{ Veg cover class } & \multicolumn{1}{c|}{1973} & \multicolumn{1}{c|}{1987} & Forest transitions & $\%$ \\
\hline Forest & $34.1 \%$ & $20.0 \%$ & Forest to forest & $51.9 \%$ \\
\hline Degraded forest & na & $12.3 \%$ & Forest to degraded & $36.2 \%$ \\
\hline lidge & $1.6 \%$ & $3.6 \%$ & Forest to edge & $9.3 \%$ \\
\hline Nonforest & $64.4 \%$ & $64.1 \%$ & Forest to nonforest & $2.6 \%$ \\
\hline
\end{tabular}

13. Urban - Forest border (Berberati) / Total area $=99496$ ha

\begin{tabular}{|c|c|c|c|c|}
\hline Forest & $24.6 \%$ & $1.3 .9 \%$ & Forest to forest & $51.9 \%$ \\
\hline Degraded forest & na & $8.9 \%$ & Forest to degraded & $36.2 \%$ \\
\hline lidge & $2.6 \%$ & $5.8 \%$ & Forest to edge & $11.6 \%$ \\
\hline Nonforest & $72.8 \%$ & $71.4 \%$ & Forest to nonforest & $0.3 \%$ \\
\hline \multicolumn{5}{|c|}{ C. Urban - (Carnot) $/$ Total area $=38696$ hat } \\
\hline liorcst & $38.9 \%$ & $14.7 \%$ & Forest to forest & $35.1 \%$ \\
\hline Degrided forest & na & $10.6 \%$ & Forest to degraded & $27.3 \%$ \\
\hline Fige & $1.1 \%$ & $12.9 \%$ & lorest to edge & $32.7 \%$ \\
\hline Nonforest & $60.1 \%$ & $61.7 \%$ & Forest to nonforest & $4.8 \%$ \\
\hline
\end{tabular}

D. Open area near Carnot / Total area $=100825$ ha

\begin{tabular}{|c|c|c|c|c|}
\hline Forest & $10.7 \%$ & $3.6 \%$ & forest to forest & $28.4 \%$ \\
\hline Degraded forest & na & $2.0 \%$ & lorest to degraded & $18.9 \%$ \\
\hline I:dge & $0.4 \%$ & $4.6 \%$ & forest to edge & $43.5 \%$ \\
\hline Nonforest & $88.9 \%$ & $89.8 \%$ & Iorest to nonforest & $9.2 \%$ \\
\hline
\end{tabular}

E. Open area cast of Amada Gaza / Total area $=100774$ ha

\begin{tabular}{|l|r|r|l|l|}
\hline E. Open area cast of Amada Gaza / Total area $=100774$ ha & & $16.6 \%$ \\
\hline Forest & $5.3 \%$ & $1.4 \%$ & Forest to forest & $26.9 \%$ \\
\hline Degraded forest & na & $1.4 \%$ & Forest to degraded & $32.5 \%$ \\
\hline Nonforest & $0.3 \%$ & $1.7 \%$ & Forest to edge & $24.0 \%$ \\
\hline F. Forested area south of Berberati / Total area = 204.323 ha & Forest to nonforest & $\% 6.0 \%$ \\
\hline Forest & $87.3 \%$ & $88.9 \%$ & Forest to forest & $2.8 \%$ \\
\hline Degraded forest & na & $2.4 \%$ & Forest to degraded & $1.1 \%$ \\
\hline Edge & $3.8 \%$ & $1.9 \%$ & Forest to coge & $0.1 \%$ \\
\hline Nonforest & $8.9 \%$ & $6.7 \%$ & Forest to nonforest & \\
\hline
\end{tabular}




\section{CONCLUSIONS AND LIMITATIONS}

Carbon inventories and emissions were estimated over the 1985 to 2001 time period using existing FAO deforestation rates and vegetation maps. The results from the model are within the bounded estimates of previously published studies. This consistency provides credibility to the methodology that was developed and employed. Of course, all studies to date have relied on existing FAO data for many key parameters, such as country-specific rates of deforestation. The FAO 1990 Tropical Forest Resources Assessment values, when they become available, will undoubtedly improve the validity and accuracy of model predictions. The remainder of this chapter discusses the conclusions of the study as well as limitations encountered related to data deficiencies and the GIS analysis.

\subsection{CONCLUSIONS}

Using current land-use trends, the land-use model results show that three countries (Ivory Coast, Zaire, and Nigeria) contributed over $50 \%$ of 1985 carbon emissions from land use change in Sub-Saharan Africa. The Ivory Coast and Nigeria carbon emissions are predicted to decline rapidly over time as their rapid rates of deforestation (7\% and $3 \%$ loss per year) deplete their forest base. Zaire is the exception because of its vast forest areas and its current low rate of deforestation (only $0.2 \%$ loss per year). Angola, the Central African Republic, Congo, and Gabon are also similar to Zaire, having low deforestation rates (respectively, $0.18 \%, 0.15 \%, 0.10 \%$ and $0.07 \%$ loss per year) with sizable forest areas. For all of the Sub-Saharan countries examined, total carbon emissions from deforestation are estimated at approximately 200 million tonnes in 1985 . This total is projected to decline to about 140 million tonnes in 2001 assuming no changes in current deforestation rates. Over the 1985 to $2(0) 1$ study period, carbon emissions are projected to average approximately 16.5 million tonnes.

The Sib-Saharan land-based carbon emissions represent a small fraction of current total global enissions of carbon, but are a significant fraction (about $20 \%$ ) of carbon emissions from global tropical deforestation. If all global forests are taken together their importance relative to world fossil fuel emissions is much more pronounced. A concerted effort in reducing deforestation rates, promoting sustainable agricultural systems, and establishing plantations in Africa and in other tropical forest areas could significantly reduce the rate of earbon dioxide buildup. Reducing the rate of earbon dioxide buildup could de iy the process of globai warming and provide the needed time to wean industrialized countries away from fossil fuels and find non-fossil fuel paths for the industrialization of developing countrics.

If deforestation aceelerated in Zaire and the other countries of the Congo basin, landbased emissions from Sub-Saharan Africa could become much more globally significant. For example, a tripling of Zaire's deforestation rate to $0.6 \% / y e a r$, still far below that of the Ivory Coast or Nigeria, would cause carbon emissions from Sub-Saharan Africa to increase by $30 \%$. If Zaire's deforestation rate was the same as the Ivory Coast's, emissions would be 500 million tonnes of carbon per year or about a tenth of current global fossil fuel emissions. If timber extraction increases significantly, as it may due to the closing of other markets in Brazil and 
Asia and the harvested land is not reforested, then emissions from Zaire could increase substantially. Quality information and statistics on land use and land-use trends are badly needed to ascertain the real risk in Zaire and the Congo basin. Current emissions from landuse change must also be considered in their historic context. Considerable loss of forest land has already occurred in Sub-Saharan Africa. The closed forests that banded Western Africa are now largely gone. The only remaining extensive tracts of intact forest are in Central Africa.

Of the three land use options considered for reducing carbon emissions, aggressive forest preservation (total halt of deforestation in conjunction with recovery of degraded forest) yiclded the greatest carbon benefit. Under this option, carbon emissions change from 152 million tonnes to a net sequestering of 62.5 million sunnes each year as the degraded forests put on new growth. Halving current deforestation rates and allowing the existing forest to recover would reduce net emissions to 21 million tonnes per year. The estimate of carbon sequestering potential with forest preservation is conservative as the estimates of both the extent of degraded forest and the degree of dro adation are conservative. More carbon, perhaps as much as 2 or 3 times more, could be sequestered during the recovery of degraded forests. It should also be noted that the preservation secnario is not a restoration scenario. That is, existing forest is preserved but former forest-land is not restored to forest.

Very aggressive agroforestry implementation also yicled significant reductions in carbon emissions. Assuming a high level of adoption (4\% of the agricultural land was converted to agroforestry each year) and assuming the agroforestry si :e contained $40 \%$ of the tree biomass of an industrial plantation, the model predicted that Sub-Saharan carbon cmissions would drop from an average of 152 to 20.2 million tonnes per year. A more realistic, but still optimistic, adoption rate of $2 \%$ per year and a lower tree biomass assumption (20\% of an industrial trec plantation) reduced emissions to 114 million tonnes per year.

Establishment of industrial plantation forests, assuming implementation rates comparable to those recommended by the Tropical Forestry Action Plan, are predicted to reduce regional carbon emission by about 5 million tonnes per year. Assuming that $0.1 \%$ of all land biologically capable of supporting industrial plantations (this includes the agricultural land base but excludes current forest land) was converted to plantation annually, the annual carbon savings were predicted to be about 10 million tonnes per year. Offsetting all industrial roundwood removals with plantations would save about 18 million tonnes of carbon annually and require the establishment of nearly $380,(K K)$ hectares each year.

The minimum costs for implementing these options were estimated to range between $\$ 25$ and $\$ 115 /$ ha for preservation, $\$ 50$ and $\$ 150$ /ha for agroforestry, and $\$ 560$ and $\$ 1,(66)$ for industrial plantations. These costs are for direct expenses (e.g., seedlings, extension, management) and do not account for institutional constraints (c.g., land tenusc arrangements); the need to purchase land; and other location specific factors. In comparing the three landuse options, industrial reforestation is perhaps the most easily implemented, although the cost per tonne of sequestered carbon is higher ( $\$ 11$ to $\$ 22 /$ tonne) than for preservation ( $\$ 3$ to $\$ 15 /$ tonne) and agroforestry (\$2 to $\$ 10 /$ tonne). The viability of implementing any of these land use options will depend on population density and rates of population growth (natural growth, migration, or resettlement) as well on other factors, such as customs and policies 
affecting the allocation of land and tenure, access to markets (i.e., infrastructure), foreign debt, government policies designed to generate foreign exchange from cash crops and timber exports, the availability of inputs and local technical skills for intensifying agriculture, and the adequacy of institutions to manage these problems.

It is imperative to begin the process of designing policies for protecting existing forests and their stores of carbon as well as policies for reducing the development pressures on these forests. There is also a need to emphasize the full package of benefits derived from intact forests (c.g., oils, nuts, fibers, etc.) and not just short-term timber and unsustainable agricultural products. In the agriculture sector, pricing policies must be changed to encourage greater output and more equality between rural and urban areas. Policies that serve to reduce the demand for unskilled labor and favor forest exploitation should also be eliminated. Moreover, the centralization of property rights, which has served to remove local incentives for conservation of forest areas, needs to be reversed to encourage local protection and management.

Forestry policies in many countries also need to be recvaluated. Overly lenient timber concessions with royalty payments below stumpage values have encouraged selective cutting and high grading, undermined forest quality, and have yielded too few revenues for governments to consider reforestation and training. There must be royalty reform that serves to bring up payments more in line with market stumpage values to provide revenues for reforestation and better forest management. There must also be policies that encourage natural regeneration of forests and the establishment of plantations for industrial purposes. Moreover, governments must lengthen concession periods to provide long-term financial interest and proper stewardship of forests.

The methodology developed in this study is well suited to analyze a single country (or subregion, e.g., Congo Basin). If a single country were analyzed, much finer geographic delineation would be possible. Moreover, specific site recommendations could be made based on model results as well as information from ground-level and local studies. The purpose of a single-country analysis could be broadened to include recommendations and land-use management options for the preservation of specific areas and for the location of plantations and agroforestry interventions. For example, the preservation of large intact tropical forests of Zaire and the protection of critical habitat areas and upland watersheds of Madagascar could be investigated in detail. In addition, a country-level analysis could include greater consideration and specificity of economic costs; institutional constraints (c.g., land tenure arrangements); and political realities. Land-use management strategies could then be based on the full range of tropical forest benefits (i.e., habitat, biodiversity, climate moderation, and soil stabilization) including carbon storage. Such specificity is not possible at a continental scale. Ideally, a country-level study would use satellite imagery to develop accurate vegetation maps and could enlist the assistance of local technical experts.

Continuing imagery analysis of Central Africa is needed to improve the information base on these forests. The difficulties in traversing this region and its poverty have hampered the collection of ground-based information on forest presence and loss. Thus, examination of older imagery is an important tool for evaluating the condition of forests in the past. Imagery analysis is also a powerful tool for evaluating current forest condition. Unfortumately, the equatorial forests of Central Africa have received scant attention from the remote sensing 
community. Consequently, the remote sensing methodology for evaluating forest change in this region is still in the developmental phase. With ground truth information, the analyses begun for this study could be refined to produce accurate estimates of iorest change in this region. Such estimates could assist FAO in its 1990 Tropical Forest Resource Assessment. FAO is taking an approach to this assessment that includes both national forestry statistics and remote imagery analysis. FAO is relying on outside agencies to support the 1990 assessment and would strongly support an initiative to continue and refine the remote imagery analysis begun with this study. ${ }^{51}$

The carbon emissions from the energy sector are relatively minor when compared with fossil fuel emissions fr om industrial and industrializing countries. Increasing energy efficiency and thereby lessening the amount of carbon emitted per unit of end-use energy generated and substituting renewable and other energy sources for fossil fuels (primarily coal) are policy initiatives that are vital for controlling global carbon emissions. As noted earlier, there may be considerable potential to reduce emissions in the houschold sector with the dissemination of more efficient stoves. Of course, the suecess of stove programs depends on whether the technology is consistent with local sociocultural patterns and whether the user has a distinet financial incentive to possess the technology. In the rapidly expanding urban areas of Africa, the diffusion of fuel-efficient stoves is likely to be much more effective than in rural areas. Initiating these programs in advance of major demographic shifts that are likely to take place may be prudent. In the power sector, the substitution of biomass fuels for fossil fucls (i.e., diesel fuel) would lessen carbon releases provided the biomass inventory is not reduced in the process. The viability of small-scale power generation with biomass has proven to very costeffective in other regions.

In sum, several general land-use policy recommendations can be made on the basis of these findings, although specific policy recommendations are not appropriate given the very broad and general scope of the project. First, the Congo basin of Central Africa shelters an enormous pool of carbon in vegetation. The countries of Zaire, Angola, Gabon, Central Africa Republic, Cameroon, and Congo contain haif the forest carbon of Sub-Saharan Africa about 30,000 million tonnes of carbon. Because of inaccessibility and fairly low population pressures, this pool is still largely intact. However, it could suffer the fate of the Amazon basin with similar carbon emissions if transportation access improves and governments do not recvaluate their overly lenient timber concession policies. Policies that promote the maintenance of this carbon pool, such as controlled logging, reforestation, reduction of agricultural and fuelwood pressures, should be pursued. Second, ine information base upon which to develop sound specific policies is extremely limited for Central Africa. Development of that information base should take high priority. Finally, as elsewhere in the tropics, deforestation in Sub-Saharan Africa is driven by agriculture, fuelwood needs, and international wood markets. These issues must be addressed if deforestation is to be successfully controlled and reforestation or affore:tation implemented. The analysis of the energy sector in SubSaharan Africa indicates that fossil fuel carbon emissions do not and probably will not play a major role in global carbon inventory changes. However, it is also apparent that savings could

\footnotetext{
${ }^{51}$ K.D. Singh, Director, Forest Resources 1990 Assessment Project, FAO Forestry Department, Rome, personal communication to Robin Graham, April 1990.
} 
be efiected to reduce levels of emissions through a variety of energy conservation and fuel substitution programs.

\subsection{STUDY LIMITATIONS}

\subsubsection{Data Deficiencies}

The single most challenging problem encountered in this analysis had to do with data limitations with regz: $d$ io land-use change. In particular, the 1981 Tropical Forest Resource Assessment dpia on land-use change are dated, and the original accuracy has been questioned. Local reports exist for some locations, hui these do not provide regional coverage and often do not use the same land-use classification schemes. Therefore local reports cannot be merged to create a continental data base.

Satellite imagery could be used to create such a data base (Booth 1989), but a satellite imagery analysis of the entire continent was far beyond the scope, time, and fundir.; of this project. Land-use change is inherently difficult to evaluate because it occurs at a fine srale (hectares) over vast expanses (millions of square kilometers). It is exiremely expensive to use fine-scale satellite imagery to evaluate land-use change over large regions; yet inexpensive, coarse-resolution imagery (1- to 4-km resolution) is difficult to interpret if the land-use change is occurring at a much finer spatial scale, as it often is in Africa. Quantifying forest degradation is especially difficult as the spectral changes between intact and degraded forest are likely to be subtle. Blends of fine- and coarse-scale imagery are needed as are methodologies for combining different scale imagery (Dale 1039, Iverson et al. 1989). This limitation is not to say that land-use changes cannot ic evaluated across large regions using satellite imagery, but rather that the methodologies for ching so are still not mature and the statistical accuracy of such evaluations is extremely difficult to assess (Nelson and Holben 1986, Malingreau and Tucker 1988, Nelson et al. 1987a, Nelson et al. 1987b).

Data on carbon storage capacity or productivity of different vegetation types are scattered and sometimes not comparable. Often only one component of the system is considered: the large woody component, the overstory, or the aboveground fraction (Millington et al. 1989, Olson et al. 1985, Brown and Lugo 1984). The numbers are often scattered across many reports, often in the "gray" literature, and therefore not easily accessed. The U.S. Department of Energy has been funding a project for the last several years solely to gather information on the carbon content of tropical forests. Data from this project were used to determine the maximum carbon that might be stored in closed forests in Africa.

If data on carbon storage in tropical vegetation types are lacking, data with which to develop empirical relationships between carbon storage and climate or soils are virtually nonexistent. Although there is an understanding if what vegetation types are likely to occur on differing soils and under various climate regimes (Woodward 1987, Walter 1973), converting that understanding to definitive empirical models of carbon and growth has not yet been done. The approach employed by this study to relate carbon storage in a vegetation type to annual rainfall and soil fertility class is based on published research relating tropical ecosystem biomass to average annual temperature and average precipitation as well as some professional judgment (Houghton et al. 1985b). 
Data on the carbon storage of fallow forest agricultural systems and agroforestry systams were not located. In both cases, carbon storage was modeled as a function of the carbon storage of crops and native vegetation.

Data on the effect of degradation of ecosystem carbon were also not located. Subsequently, a $35 \%$ ra'uction in ecosystem carbon was assumed. Undoubtedly, there are many areas where depletion has been greater and others where it ias been less. Such numbers are difficult to obtain in the field unless there exists a combination of degraded land and protected, intact land in the same location with the same soils and local climate.

The accuracy of the vegetation map of Africa, on which much of the analysis depends, is difficult to quantitatively assess. Some regicns of the map were developed from other vegetation ruaps produced as far back as 1932. This is particularly true of the central equatoriai region of Africa. The satellite imagery analysis of this region suggests that the map is generplly correct but that the vegetation class boundaries may not be very accurate.

One of the major problems encountered in any regional-scale resource analysis is data incompatibilities. In performing a natural-resource analysis, one must bring together data from diverse sources-data which were not designed to be meshed with each other. Often the class definitions used within a particular data file arc found to be imprecise. Fortunately the two primary data sources (the FAO vege/ation map and the FAO/UNEP Forest Resources of Tropical Africa Report) used in this report were developed by the same agency and the agency could provide clarification when needed. Nonetheless, there were vegetation classes for which there were no correspondences between the two data sets even though they were developed by the same agency.

\subsubsection{GIS Analysis Deficiencies}

The study benefitted from the availability of digital continental maps of vegetation, soil units, and annual rainfall for Africa. Digital maps are not stored in libraries that are readily accessible. Generally, a map has been digitized by a user or user group (at much expense and labor), and access (and even the knowledge of its existence) is largely a matter of personal contacts. Much of the initial labor in this phase of the project was dedicated to locating such maps and getting permission to use them. Furthermore, digital data files are uniquely dependent on the GIS used in developing them. Often there are computer and software incompatibilities between different systems, and transferring the data becomes difficult and technically demanding.

Some significant GIS difficulties were encountered with the digitai FAO vegetation map. The map was pocily documented and its coordinate system was unrelated to the location of the continent of Africa. Although the digital map created a paper map that was obviously the continent of Africa, specific latitude or longitudes could not be accurately identified on the map, making it impossible to point sample the map to create the required vegetation data base. After extensive inquiries, a coordinate system was forced on to the file by using the GIS to visually overlay the vegetation map with another digital map of Africa, then transfer its coordinate system. The significance is that the vegetation point locations may be off by 5 to $40 \mathrm{~km}$ in some places. 
GIS difficultics were also encountered with the zone map, which was created using a 1:5,000,000 scale, Chamberlai trimetric projection, and the National Geographic map of the politica' boundaries $\mathrm{r} f$ Afrira as the base map. In sampling this map, numerous cases were found in which the country identity of a point at a specific letitude and longitude as identified from this map was not the same as the country identity at the same latitude and longitude on the FAO/UNEP political boundary map. Because there was no way to resolve this discrepancy between maps, all points that had mismatched country identiiies were deleted from the analysis. Deleting points from the file meant that the density of points (number of sampling points per 1000 square kilometers) varied among zones and among countries.

Because a regional analysis was being conducted, the point-sampling methodology tended to slight very small countries (i.e., there are few points in small countries so the "accuracy" of einis , ons from small countries is more suspect). This was judged acceptable, however, as it is the larger countries that will dominate land-use carbon cmissions because emissions are a function of land-use area.

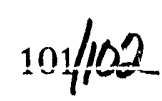


APPENDIX 1

CONVERSION FACTORS AND ENERGY VALUES USED IN ENERGY ANALYSIS

$103 / 104$ 


\section{Rencwable Fuels Conversions}

\section{Bagasse}

Energy range $\quad 8380-8740 \mathrm{Btu} / \mathrm{lb}$

Value used

$8500 \mathrm{Btu} / \mathrm{lb}$

therefore,

or,

$$
1 \text { tonne bagasse }=0.472 \mathrm{TOE}
$$

Amount of carbon $\quad 44-50 \%$

Value used $\quad 46 \%$

therefore,

1 tonne bagasse $=0.46$ tonne carbon

Fuel wood
Energy value
Density
$3500 \mathrm{kcal} / \mathrm{kg}$
$500 \mathrm{~kg} / \mathrm{m}^{3}$

therefore,

$$
1 \mathrm{~m}^{3} \text { fuelwood }=500 \mathrm{Kg} / \mathrm{m}^{3} \times 3500 \mathrm{Kcal} / \mathrm{Kg} \times 1000 \mathrm{cal} / 1 \mathrm{Kcal}
$$

or,

$1 \mathrm{~m}^{3}$ fuel wood $=0.175 \mathrm{TOE}$

(from Marland)

Amount of carbon $\quad 50-52 \%$

therefore,

or,

$1 \mathrm{~m}^{3}$ fuel wood $=0.26$ tonne carbon 


\begin{tabular}{||l|r|r|r|r|c|}
\hline \multicolumn{5}{|c|}{$\begin{array}{l}\text { Energy Table } \\
\text { Fossil Fuels }\end{array}$} \\
\hline \multirow{2}{*}{ Fuel } & \multicolumn{5}{c|}{ TOE/tonne } \\
\cline { 2 - 7 } & Btu/lb & Btu/gal & $\mathrm{kJ} / \mathrm{kg}$ & $\mathrm{lb} / \mathrm{gal}$ & Fuel \\
\hline LP gas & 21,000 & 89,000 & 48,800 & 4.24 & 1.19 \\
\hline $\begin{array}{l}\text { Residual } \\
\text { iil }\end{array}$ & 18,300 & 145,700 & 42,500 & 7.96 & 1.016 \\
\hline $\begin{array}{l}\text { Aviation } \\
\text { gasoline }\end{array}$ & 21,750 & 137,000 & 50,600 & 6.3 & 1.207 \\
\hline Kerosene & 19,000 & 129,600 & 44,200 & 6.82 & 1.055 \\
\hline Jet Fuel & 20,000 & 130,000 & 46,500 & 6.5 & 1.11 \\
\hline Gasoline & 20,000 & 123,000 & 46,500 & 6.15 & 1.11 \\
\hline $\begin{array}{l}\text { Dicsel } \\
\text { fuel }\end{array}$ & 18,800 & 122,200 & 43,700 & 6.5 & 1.044 \\
\hline
\end{tabular}

Conversion Factors

$1055.04 \mathrm{~J}=1 \mathrm{Btu}$
$41.9 \times 10^{9} \mathrm{~J}=1 \mathrm{TOE}$
$0.4536 \mathrm{kgf}=1 \mathrm{lb}$
$4.186 \mathrm{~J}=1$ calorie

Sample Conversion of tonnes to TOE 


\section{APPENDIX 2}

ENERGY CONSUMPTION BY COUNTRY

107/108 


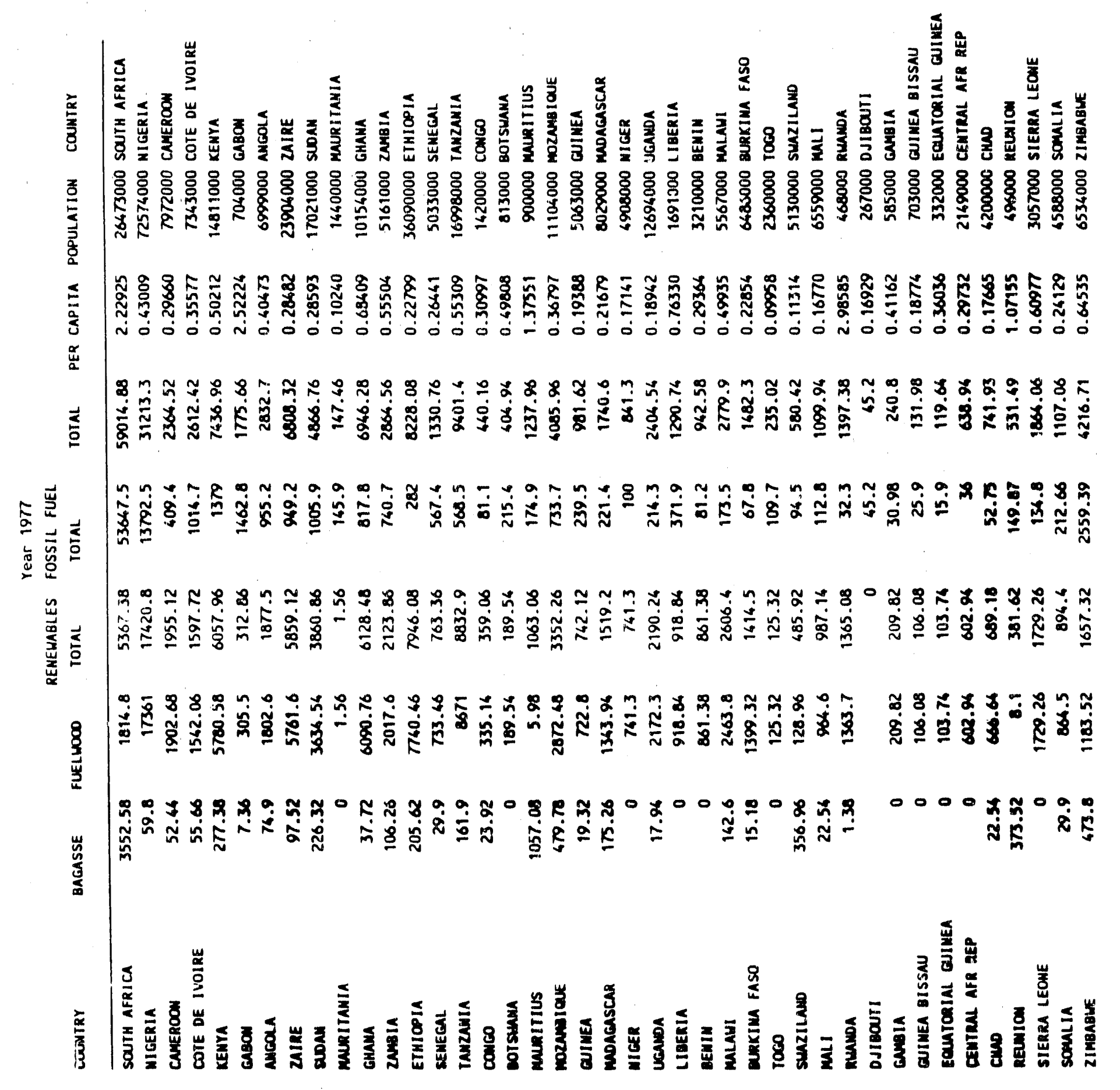




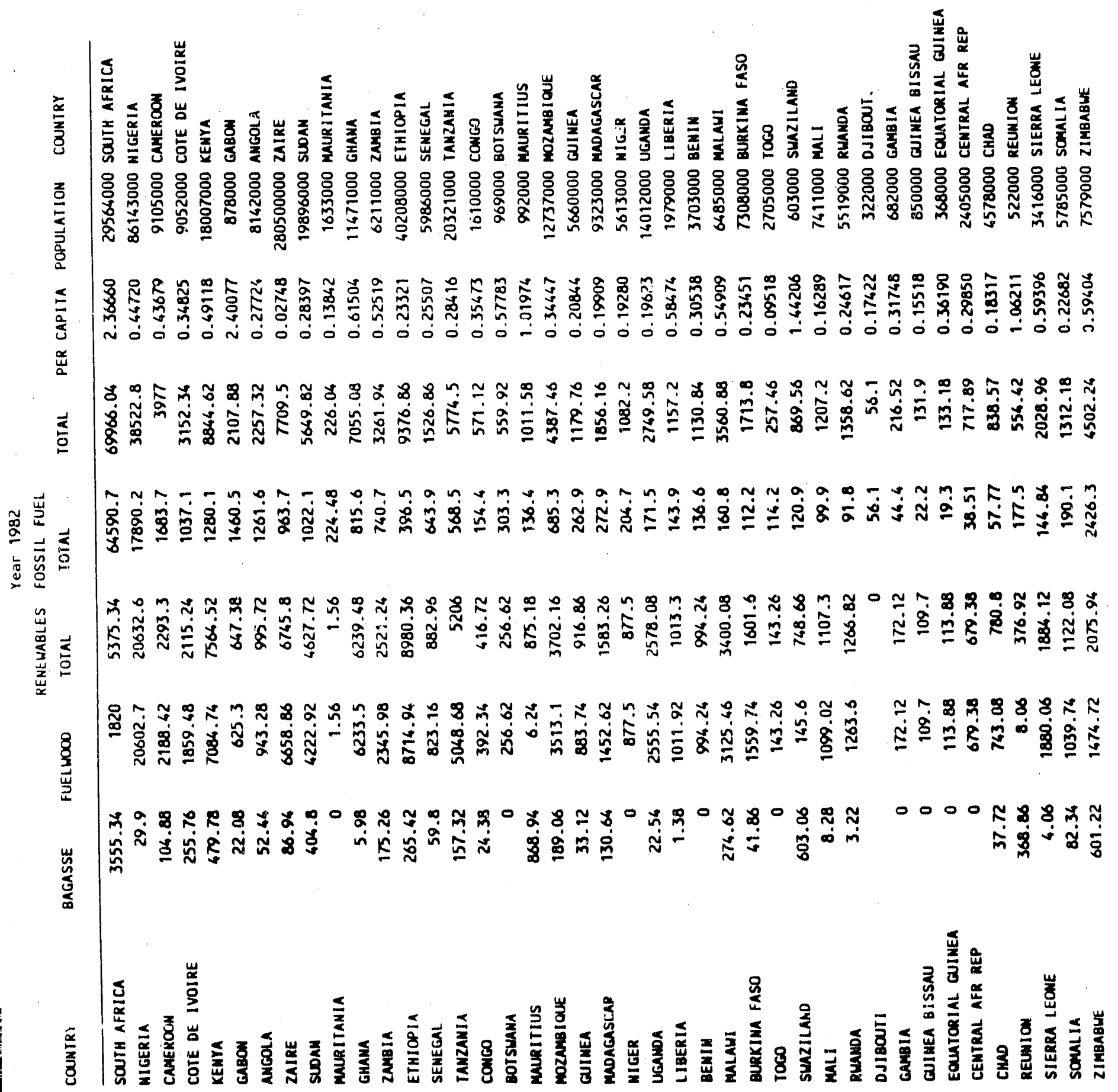




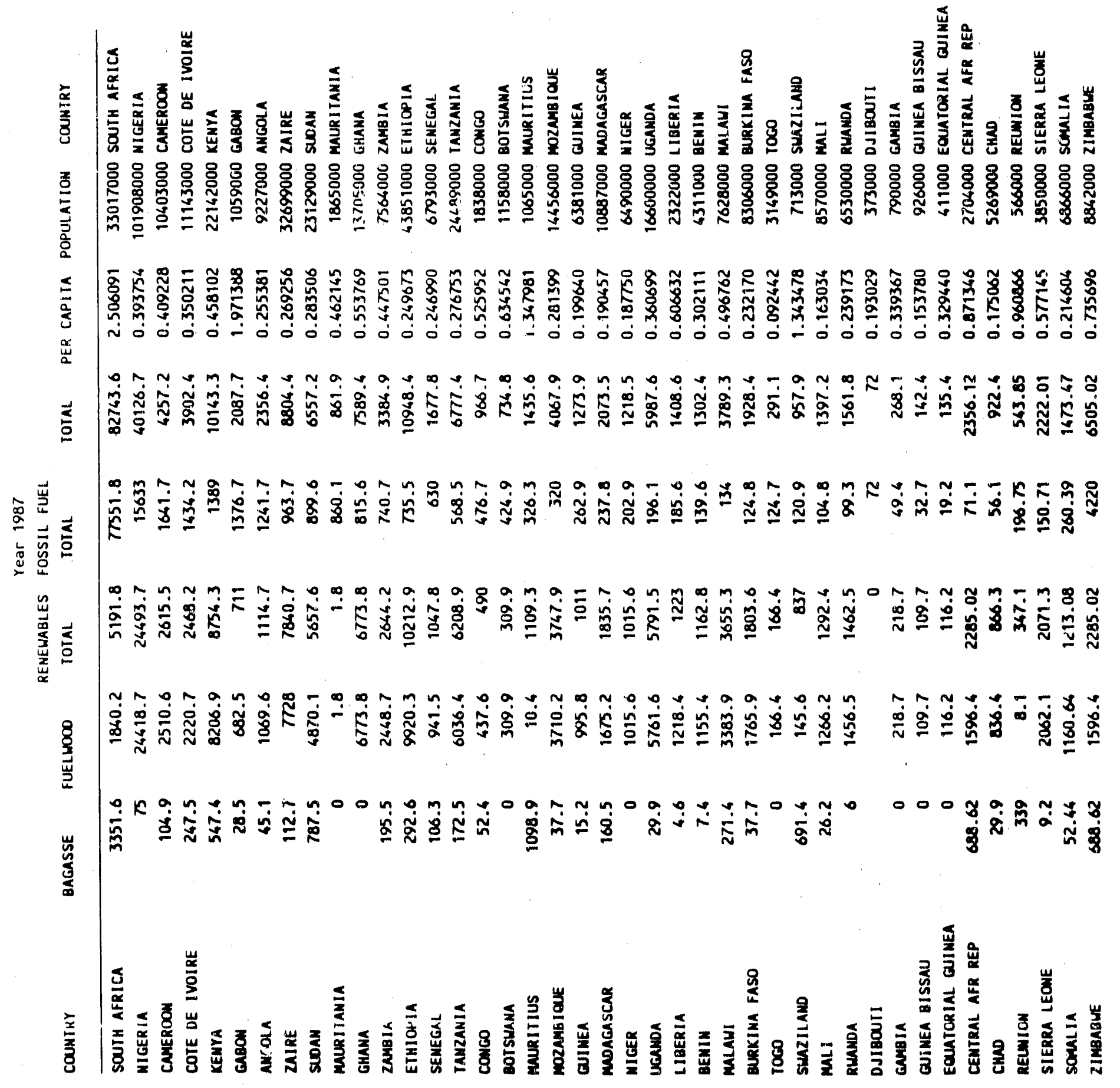




\begin{tabular}{|c|c|c|c|c|c|c|c|c|c|}
\hline COUNTRY & TOTAL & TOTAL & TOTAL & $\begin{array}{l}\text { KEMEWAULE F } \\
\text { TOTAL }\end{array}$ & $\begin{array}{c}\text { FOSSIL } \\
\text { TOTAL }\end{array}$ & TOTAL & $\begin{array}{l}\text { ENEWABLE } \\
\text { TOTAL }\end{array}$ & $\begin{array}{l}\text { FOSSIL } \\
\text { TOTAL }\end{array}$ & TOTAL \\
\hline NIGERIA & 19747 & 11517 & 23264 & 13898 & 14938 & 28837 & 16511 & 13054 & 29564 \\
\hline ETHIOPIA & 5421 & 235 & 5657 & 6138 & 331 & 6469 & $69 \pi$ & 614 & 7591 \\
\hline KENYA & 4176 & 1151 & 5327 & 5261 & 1069 & 6330 & 6085 & 1160 & 7245 \\
\hline ZAIRE & 3978 & 793 & 4771 & 4571 & 805 & 5376 & 5317 & 805 & 6121 \\
\hline ZIMBABWE & 1283 & 2137 & 3420 & 1610 & 2026 & 3636 & 1781 & 3524 & $\$ 305$ \\
\hline SOUTH AFRICA & 4867 & 44796 & 49663 & 4873 & 53933 & 58846 & 4678 & 64756 & 69433 \\
\hline ALL OTHERS & 35623 & 9533 & 45155 & 36558 & 11173 & 47731 & 44510 & 12190 & 56700 \\
\hline TOTAL & 67094 & 70162 & 137256 & 72910 & 84275 & 157135 & 85858 & 96101 & 181959 \\
\hline GHANA & 4138 & 683 & 4829 & 4202 & 681 & 4883 & 4559 & 681 & 5240 \\
\hline SUOAN & 2670 & 840 & 3519 & 3258 & 853 & 4119 & 4086 & 39 & 4837 \\
\hline TANZANIA & 6003 & 475 & 6477 & 3560 & 475 & 4034 & 4239 & $4 \pi 5$ & 4714 \\
\hline UGANOA & 1489 & 179 & 1660 & 1743 & 143 & 1886 & 3908 & 164 & 4072 \\
\hline CAMEROON & 1335 & 342 & 1676 & 1581 & 1406 & 2987 & 1797 & 1371 & 3168 \\
\hline COIE DE IVOIRE & 1095 & 847 & 1942 & 1514 & 866 & 2380 & 1748 & 1198 & 2946 \\
\hline MOZAMBIOUE & 2426 & 613 & 3038 & 2559 & 572 & 3131 & 2536 & 267 & 2803 \\
\hline MALAWI & 1805 & 145 & 1950 & 2386 & 134 & 2520 & 2556 & 112 & 2660 \\
\hline ZAMBIA & 1467 & 618 & 2086 & 1759 & 618 & $23 \pi$ & 1849 & 618 & 2467 \\
\hline CENTRAL AFR REP & 406 & 30 & 436 & 457 & 32 & 489 & 1781 & 59 & 1840 \\
\hline ANGOLA & 1290 & 798 & 2088 & 689 & 1053 & 1742 & 766 & 1037 & 1803 \\
\hline GABON & 213 & 1221 & 1435 & 444 & 1220 & 1663 & 489 & 1150 & 1638 \\
\hline SIERRA LEONE & 1164 & 113 & 1277 & 1270 & 121 & 1391 & 1397 & 126 & 1523 \\
\hline MADAGASCAR & 1084 & 185 & 1269 & 1112 & 228 & 1340 & 1292 & 199 & 1499 \\
\hline MAURITIUS & 1089 & 146 & 1235 & 896 & 114 & 1010 & 1135 & 272 & 1407 \\
\hline BURKINA FASO & 957 & 57 & 1014 & 1093 & 94 & 1187 & 1227 & 104 & 1331 \\
\hline SENEGAL & 524 & 474 & 998 & 615 & 538 & 1953 & 743 & 526 & 1269 \\
\hline RWANDA & 919 & 27 & 946 & 854 & 77 & 930 & 986 & 83 & 1069 \\
\hline SOMALIA & 613 & 178 & 790 & 784 & 159 & 943 & 835 & 217 & 1052 \\
\hline LIBERIA & 618 & 311 & 929 & 683 & 120 & 803 & 825 & 155 & 980 \\
\hline MALI & 672 & 94 & 767 & 748 & 83 & 832 & 879 & 88 & 967 \\
\hline SWAZILAND & 453 & 79 & 532 & 717 & 101 & 818 & 807 & 101 & 908 \\
\hline QUINEA & 506 & 200 & 706 & 629 & 220 & 848 & 686 & 220 & 905 \\
\hline BENIN & 580 & 68 & 648 & 669 & 114 & 783 & 785 & 117 & 902 \\
\hline NIGER & 499 & 84 & 582 & 591 & 179 & 762 & 683 & 169 & 853 \\
\hline CONGO & 250 & 68 & 318 & 289 & 129 & 418 & 348 & 398 & 746 \\
\hline MAURITAANIA & 1 & 122 & 123 & 1 & 187 & 188 & 1 & 718 & 719 \\
\hline CHAD & 472 & 44 & 516 & 539 & 48 & 587 & 594 & 47 & 640 \\
\hline ROTSWANA & $: 28$ & $: 30$ & 507 & 173 & 253 & 426 & 209 & 355 & 563 \\
\hline REUNION & 389 & 125 & 514 & 384 & 148 & 532 & 353 & 164 & 518 \\
\hline roco & 84 & 92 & 176 & 96 & 95 & 192 & 112 & 104 & 216 \\
\hline GNABIA & 141 & 26 & 167 & 116 & 37 & 153 & 147 & 41 & 188 \\
\hline CUINEA BISSAU & 71 & 22 & 93 & 74 & 19 & 92 & 74 & 27 & 101 \\
\hline EOUATORIAL CUINEA & 70 & 13 & 83 & $\pi$ & 16 & 93 & 78 & 16 & 94 \\
\hline DJIBOUTI & 0 & 38 & 38 & 0 & 47 & 47 & 0 & 60 & 60 \\
\hline
\end{tabular}




\begin{tabular}{|c|c|c|c|c|c|c|c|c|c|}
\hline & & Year 1977 & & & Year 1982 & & & ear 1987 & \\
\hline & RENEWABLES $F$ & FOSSIL FUEL. & & RENEWABLES & FOSSIL FUEL & & RENEWABLE & FOSSIL & \\
\hline COUNTRY & TOTAL & TOTAL & TOTAL & TOTAL & TOTAL & TOTAL. & TOTAL & TOTAL & TOTAL' \\
\hline$N ! G E R I A$ & 17421 & 13793 & 31213 & 20633 & 17890 & 38523 & 24494 & 15633 & 40127 \\
\hline ETHIDPIA & 7946 & 282 & 8228 & 8980 & 397 & 9377 & 10213 & 736 & 10948 \\
\hline KENYA & 6058 & 1379 & 7437 & 7365 & 1280 & 8845 & 8754 & 1389 & 10143 \\
\hline ZAIRE & 5859 & 949 & 6808 & 6746 & 964 & 7709 & 7841 & 964 & 8804 \\
\hline GHANA & 6128 & 818 & 6946 & 6239 & 816 & 7055 & 6774 & 816 & 7589 \\
\hline TANZANIA & 8833 & 569 & 9401 & 5206 & 569 & 5775 & 6209 & 569 & 6777 \\
\hline ALL OTHERS & 37789 & 12589 & 50378 & 42882 & 14423 & 57305 & 52687 & 17434 & 70121 \\
\hline SOUTH AFRICA & 5367 & 53648 & 59015 & $53 \pi 5$ & 64591 & 69966 & 5192 & 77552 & 82744 \\
\hline TOTAL, SSA & 95409 & 84026 & 179427 & 103626 & 100928 & 204554 & 122163 & 115091 & 237255 \\
\hline SUDAN & 3860.86 & 1005.9 & 4866.76 & 4627.72 & 1022.1 & 5649.82 & 5657.6 & 899.6 & 6557.2 \\
\hline ZIMBABWE & 1657.32 & 2559.39 & 4216.71 & 2075.94 & 2426.3 & 4502.24 & 2285.02 & 4220 & 6505.02 \\
\hline UGANDA & 2190.24 & 214.3 & 2404.54 & 2578.08 & 171.5 & 2749.58 & 5791.5 & 196.1 & 5987.6 \\
\hline CAMEROON & 1955.12 & 409.4 & 2364.52 & 2293.3 & 1683.7 & 3977 & 2615.5 & 1641.7 & 4257.2 \\
\hline MOZAMBIQUE & 3352.26 & 733.7 & 4085.96 & 3702.16 & 685.3 & 4387.46 & 3747.9 & 320 & 4067.9 \\
\hline COTE DE IVOIRE & 1597.72 & 1014.7 & 2612.42 & 2115.24 & 1037.1 & 3152.34 & 2468.2 & 1434.2 & 3902.4 \\
\hline MALAWI & 2606.4 & 173.5 & 2779.9 & 3400.08 & 160.8 & 3560.88 & 3655.3 & 134 & 3789.3 \\
\hline ZAMBIA & 2123.86 & 740.7 & 2864.56 & 2521.24 & 740.7 & 3261.94 & 2644.2 & 740.7 & 3384.9 \\
\hline ANGOLA & 1877.5 & 955.2 & 2832.7 & 995.72 & 1261.6 & 2257.32 & 1114.7 & 1241.7 & 2356.4 \\
\hline CENTRAL AFR REP & 602.94 & 36 & 638.94 & 679.38 & 38.51 & 717.89 & 2285.02 & 71.1 & 2356.12 \\
\hline SIERRA LEONE & 1729.26 & 134.8 & 1864.06 & 1884.12 & 144.84 & 2028.96 & 2079.3 & 150.71 & 2222.01 \\
\hline GABON & 312.86 & 1462.8 & 1775.66 & 647.38 & 1460.5 & 2107.88 & 711 & 1376.7 & 2087.7 \\
\hline MADAGASCAR & 1519.2 & 221.4 & 1740.6 & 1583.26 & 272.9 & 1856.16 & 1835.7 & 237.8 & 2073.5 \\
\hline BURKINA FASO & 1414.5 & 67.8 & $148 \% .3$ & 1601.6 & 112.2 & 1713.8 & 1803.6 & 124.8 & 1928.4 \\
\hline SENEGAL & 763.36 & 567.4 & 1330.76 & 882.96 & 643.9 & 152.6 .86 & 1047.8 & 630 & 1677.8 \\
\hline RWANDA & 1365.08 & 32.3 & 1397.38 & 1266.82 & 99.8 & 1358.62 & 1462.5 & 99.3 & 1561.8 \\
\hline SOMALIA & 894.4 & 212.66 & 1107.06 & 1122.08 & 190.1 & 1312.18 & 1213.08 & 260.39 & 1473.47 \\
\hline MAURITIUS & 1063.06 & 174.9 & 1237.96 & 875.18 & 136.4 & 1011.58 & 1109.3 & 326.3 & 1435.6 \\
\hline LIBERIA & 918.84 & 371.9 & 1290.74 & 1013.3 & 143.8 & 1157.2 & 1223 & 185.6 & 1408.6 \\
\hline MALI & 387.14 & 112.8 & 1099.94 & 1107.3 & 99.9 & 1207.2 & 1292.4 & 104.8 & 1397.2 \\
\hline BENIN & 861.38 & 81.2 & 942.58 & 994.24 & 136.8 & 1130.84 & 1162.8 & 139.6 & 1302.4 \\
\hline GUINEA & 742.12 & 239.5 & 981.62 & 916.86 & 262.9 & 1179.76 & 1011 & 262.9 & 1273.9 \\
\hline NIGER & 749.3 & 100 & 841.3 & 877.5 & 204.7 & 1082.2 & 1015.6 & 202.9 & 1218.5 \\
\hline CONGO & 359.06 & 81.1 & 440.16 & 416.72 & 154.4 & 571.12 & 490 & 476.7 & 966.7 \\
\hline SWAZILAND & 485.92 & 94.5 & 580.42 & 748.66 & 120.9 & 869.56 & 837 & 120.9 & 957.9 \\
\hline CHAD & 689.18 & 52.75 & 741.93 & 780.8 & 57.77 & 838.57 & 866.3 & 56.1 & 922.4 \\
\hline MAURITANIA & 9.56 & 145.9 & 147.46 & 1.56 & 224.48 & 228.04 & 1.8 & 860.1 & 861.9 \\
\hline BOTSWANA & 189.54 & 215.4 & 404.94 & 256.62 & 303.3 & 559.92 & 309.9 & 424.9 & 734.8 \\
\hline REUNION & 381.62 & 149.87 & 531.49 & 376.92 & 177.5 & 554.42 & 347.1 & 196.75 & 543.85 \\
\hline TOCO & 125.32 & 109.7 & 235.02 & 143.26 & 114.2 & 257.46 & 166.4 & 124.7 & 291.1 \\
\hline GAMBIA & 209.82 & 30.98 & 240.8 & 172.12 & 44.4 & 216.52 & 218.7 & 49.4 & 268.1 \\
\hline GUINEA BISSAU & 106.08 & 25.9 & 131.98 & 109.7 & 22.2 & 131.9 & 109.7 & 32.7 & 142.4 \\
\hline EOUATORIAL GUINEA & 103.74 & 15.9 & 199.64 & 113.88 & 19.3 & 133.18 & 116.2 & 19.2 & 135.4 \\
\hline DJIBOUTI & 0 & 45.2 & 45.2 & 0 & 56.1 & 56.1 & 0 & 72 & 72 \\
\hline
\end{tabular}


APPENDIX 3

COMPARISON OF FAO AND AVHRR VEGETATION MAPS

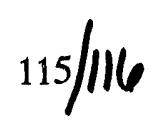




\section{INTRODUCTION}

These plots (or maps) were generated using SAS software in order to compare the FAO and the AVHRR vegetation maps in the region of Central Africa (Chapter 4). The FAO vegetation values and the AVHRR vegetation values at the same point locations were compared and the values (or differences in values) plotted by point location (i.c., latitude and longitude). These plots show locations where the two maps agreed, disagreed, and how they disagreed, with regard to the three vegetation classes, thereby providing a visual means of comparison between the two maps. 
Fig. A-1. AVHRR Vegetation Map of Central Africa Showing the Location of Forest, Savanna and Mixed Forest/Savanna.

LAT

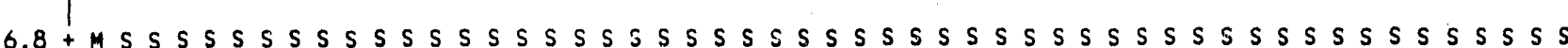

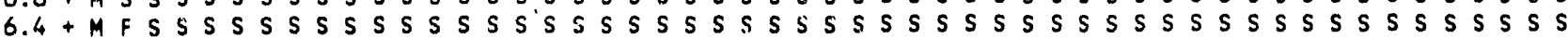
$6.0+F S S S S S S M M S S S S S S S S S S S S S S S S S S S S S S S S S S S S S S S S S S S S S S S S S S$ $5.6+F M S S M S M M M F S S S S S S S S S S S S S S S S S S S S S S S S S S S S S S S S S S S S S S S S S S$ $5: 2+F M S S M M M M M M F S S S S S S S S S S S S S S S S S S S S S S S S S S S S S S S S S S S S S S$

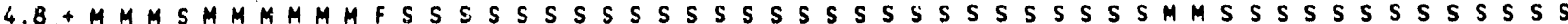
$4.4+M F F M S S S F F F F S M S S S M M M S S M S F S S S S S S S M S S S S M M M M M S S S S S S S S S S S S$ $4.0+M F M F F F F F F F F$ FMFFMSMFSSSSSSFFMSSFFFMMMMMSSSSSSSSSS $3.6+M F F F F F F F F F F F F F$ F MFFFFSSSSSSFSFMMFFFFMMFMSSMMSMSSSSS $3.2+F F F F F F F F F F F F$ FFMFFFF MSSMMMFFFFFFFFFFFFFFMMFMMMSMSS $2.8+F F F F F F F F F F F F F F F F F F F F F F+M F M F F F F F F F F F F F F F F F F M M M M M M S$ $2.4+F F F F F F F F F F F F F F F F F F F F F F F F F F F F F F F F F F F F F F F F F F F F F F F S$ $2.0+F F F F F F F F F F F F F F F F F F F F F F F F F F F F F F F F F F F F F F F F F F F F F F F$ $1.6+F F F F F F F F F F+F F F F F F F M F F F F F F F F F F F F F F F F F F F F F F F F F F$ $1.2+F F F F F F F F F F F F F F F F F F F F F F F F F F F F$ FFFFFFFFFFFFFFFFFFFFFS $0.8+F F F F F F F F F F F F F F F F F F F F F F F F F F F F F F F F F F F F F F F F F F F F F F F F F F F$ $0.4+F F F F F F F F F F F F F F F F F F F F F F F F F F F F F F F F F F F F F F F F F F F F F F F F$ $0.0+F F F F F M F F F F F F F F M M F F F F F F F F F F F F F F F F F F F F F F F F F F F F F F F F$ $-0.4+F F F F F F F F F F F S M S M M F F F F F F F F F F F F F F F F F F F F F F F F F F F F F F F F$ F F $-0.8+F F F F F F F F F F F S S S M M F F F M F F F F F F F F F F F F F F F F F F F F F F F F F F F F F F F$ $-1.2+F F F F F F F F F M S S S S M M M M F F F F F F F F F F F F F F F F F F F F F F F F F F F F F F$ $-16+F F F F F F F M S S S S S M M M F M M F F F F F F F F F F F F F F F F F F F F F F$ FFF $-2.0+F F F F F F F F F$ S SSSSSMMFFFMFFFFFFFFFFFFFFFFFFFFFFFFFFF $-2.4+F M F M F F F F F S S S S S S M M M M F F F F F F F F F$ FFFF $-2.8+F F M F F F F M S S S S S M M M M F F F F F F F F M F F F F F F F M F M F F F F F F F F F$ $-3.2+$

$-3.6+$

$-4.0+$

$-4.4+$

$-4.8+$

$-5.2+$

$.5 .6+$

$-6.0+$

$-6.4+$

$-6.8+$

$-7.2+$

$-7.6+$

$-8.0+$ $F M M F F F F F S S S S M M M M M M M F F F T F F F M F F M M F M F M M F$

$F M F M F F F F M M S M M M M S M M M F F F F F F M M F M M M M M M F F F F F F M F F M S$ $M M M M M M M S M M M M M M M S M M M M F F M M M M F F M M M M M S F F F S S M F$ MS FF MMMFSMMMSSMMMMMMSFFFFFMFMFFMMMSMSSSSSMSSS SS FFFMFMMFFMMSMMSSMSSFFFFMMMFFFSMMMSSSSMMSS $S$ S $M M F F F F M M S S M F M S S S S M M M S F F M M F F M F M S M S S S S S M S S S$ S $M M M M M M M S S M F F S S S S S S S S F S M M M F M M M S S S S S S S S S M S S S$ S

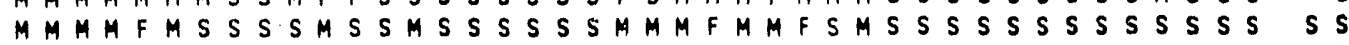
SFFMFF SSMFMSSSSSSSSSSFFFMMMSSSSSSSSSS S S S S FMSSSSSSFFFSMFSSSSSSSMMMMMMSSSSSSSSSSSSSS $M F S S S M S S M S S F S M S S S S S S S M M M M M M S S S S S S S S S S S S S S$ SMSFSSSFSSSFSMSMMSSMSMMMMSMMSS SS SS S S S S S S S S

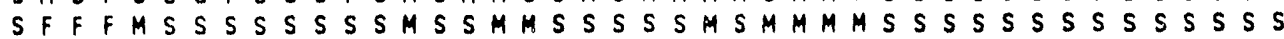

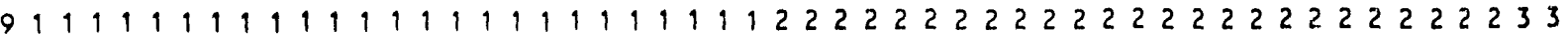
.00011222334445566677888990001122223344455666778889900

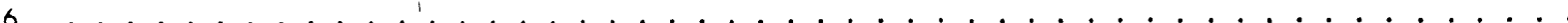
0482604826048260482604826048260482604826048260482604

LONG 
Fig. A-2. FAO Vegetation Map Showing the Location of Forest, Savanna and Mixed Forest/Savanna.

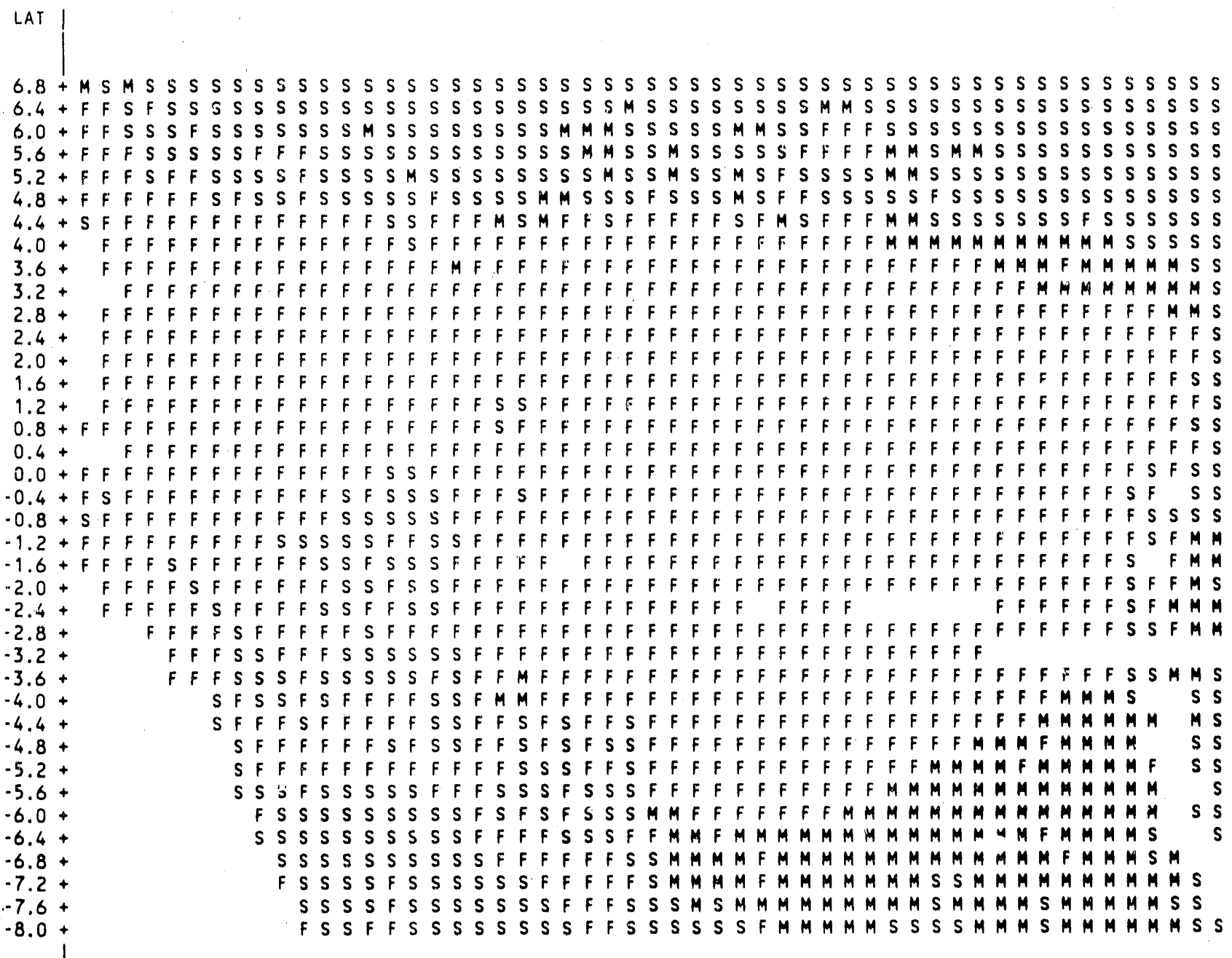

91119111911911111111111111122222222222222222222222222233 .0001122233444556667788899000112223344455666778889900 $6 \ldots \ldots+\ldots$ 0482604826048260482604826048260482604826048260482604

LONG 
Fig. A-3. Locations where there is Agreement between AVHRR and FAO Maps with regard to the Location of Forest, Savanna and Mixed Forest/Savanna.

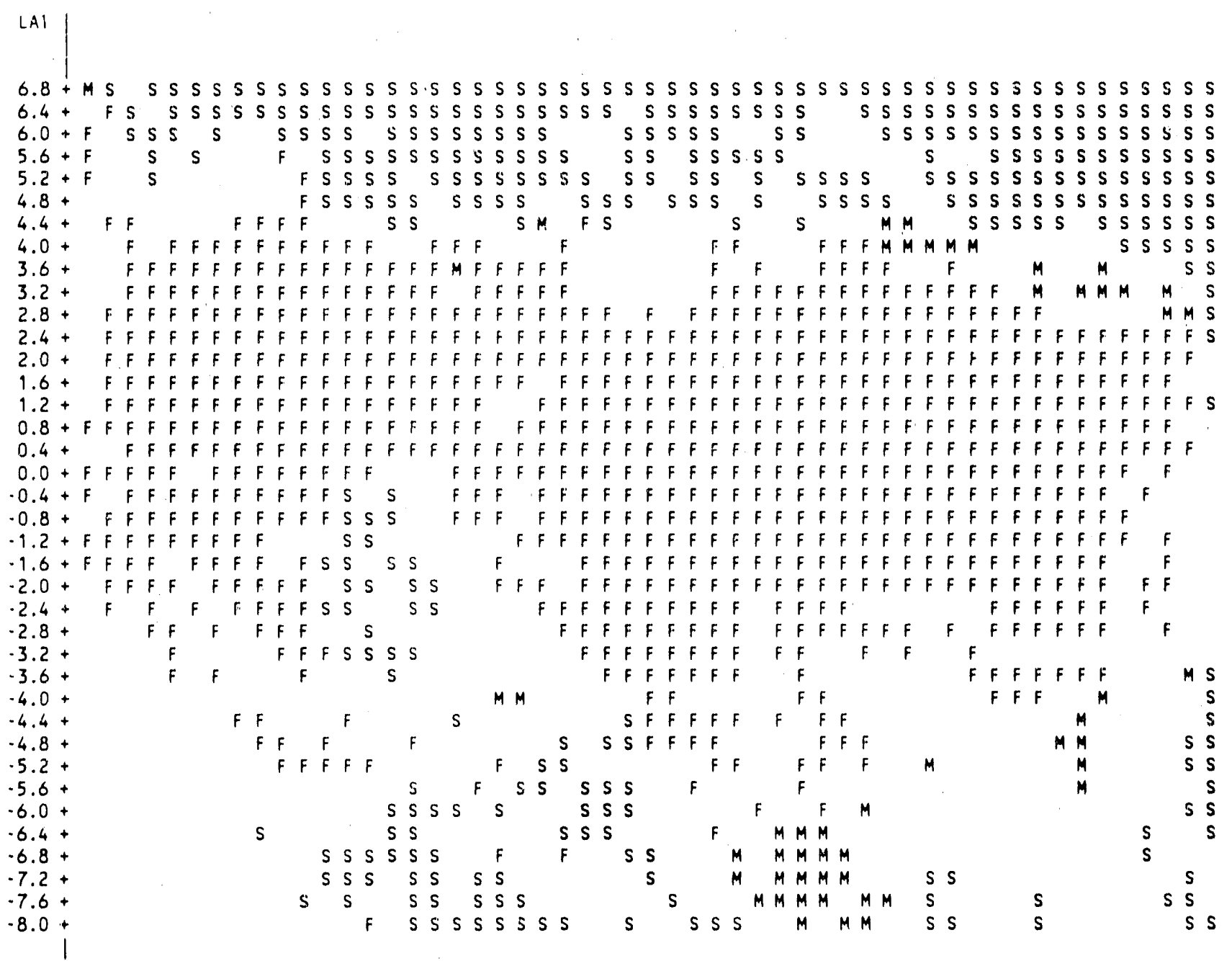

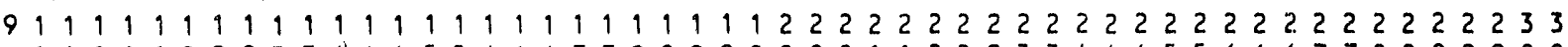
. 0001122233444556667788899000112223344455666778839900

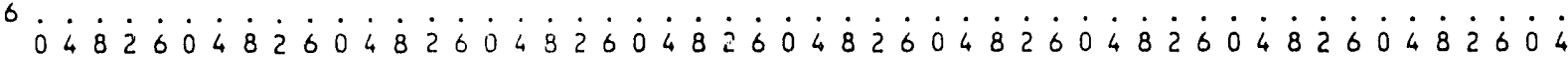
LONG 
Fig. A-4. Locations where FAO maps Indicate more Forest than AVHRR Map.

'\&' svmbolizes locations where Savanna (as per AVHRR) is indicated as Forest (by FAO), '\$' symbolizes locations where Mixed Forest/Savanna (as per AVHRR) is indicated as Forest (by FAO) and '*' symbolizes locations where Savanna (as per AVHRR) is indicated as Mixed

Forest/Savanna (by FAO).

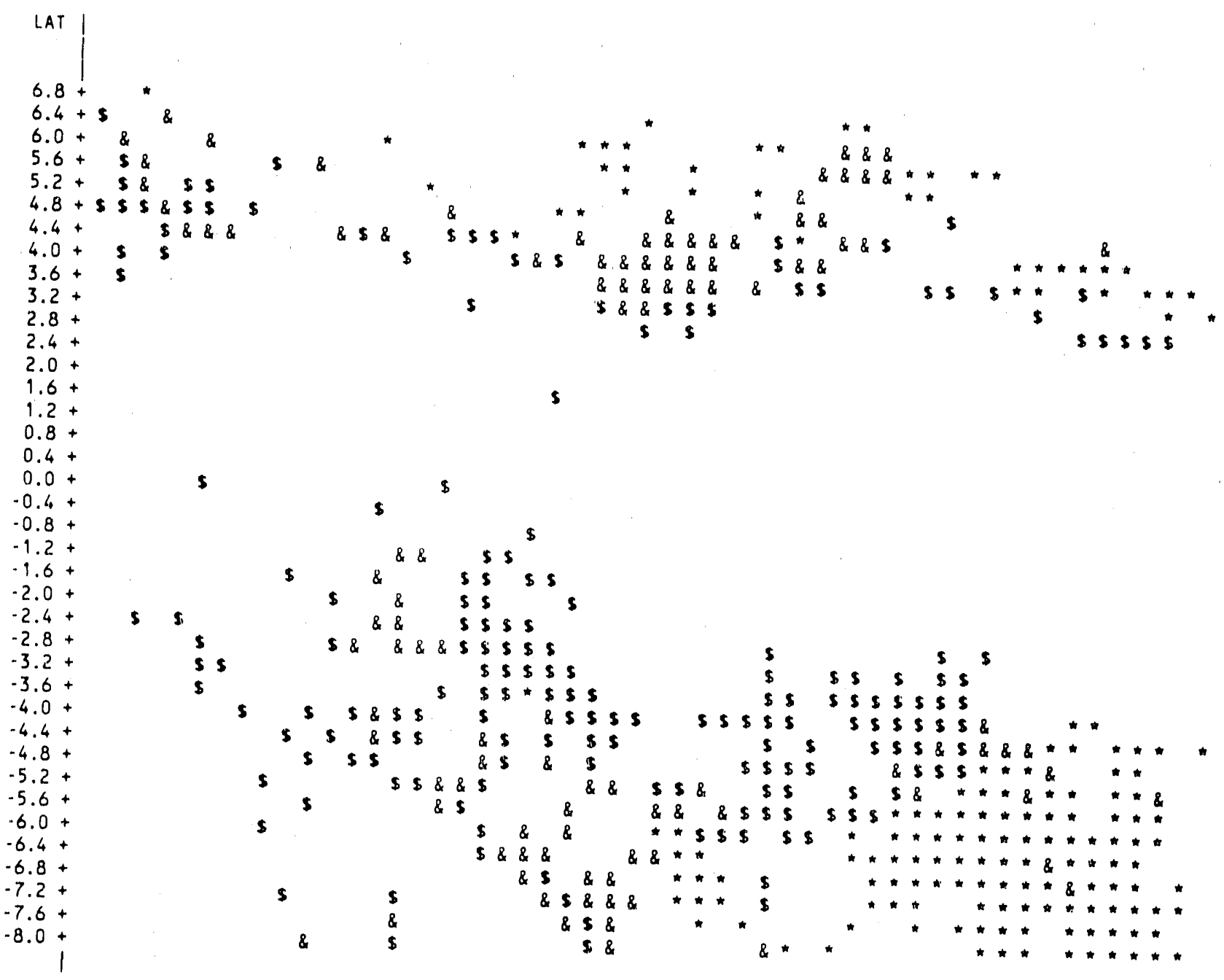

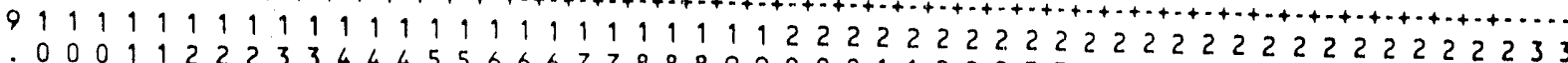
$\dot{0} 000112223344455666778889900011222334444556667788899030$ 04826048260482604826048260482604826018200. 
Fig. A-5. Locations where AVHRR Maps Indicate more Forest than FAO Map. '\#' symbolizes locations where Savanna (as per FAO) is indicated as Forest (by AVHRR), '@)' symbolizes locations where Mixed Forest/Savanna (as per FAO) is indicated as Forest (by AVHRR), and '\%' symbolizes locations where Savanna (as per FAO) is indicated as Mixed/Savanna (by FAO).

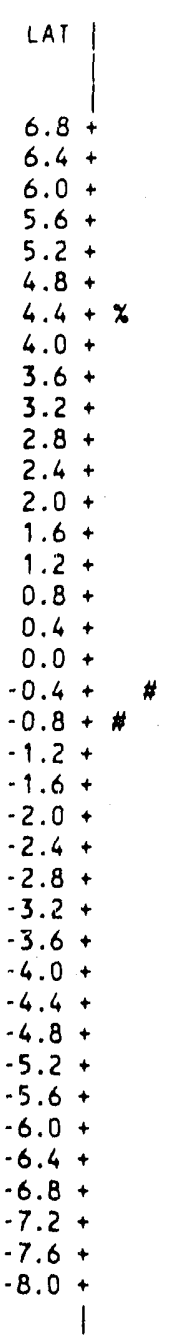

$$
\begin{aligned}
& x \times x^{x} x \\
& \begin{array}{l}
x \times x \\
x \times x
\end{array}
\end{aligned}
$$

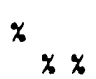

$$
\%
$$$$
x *
$$

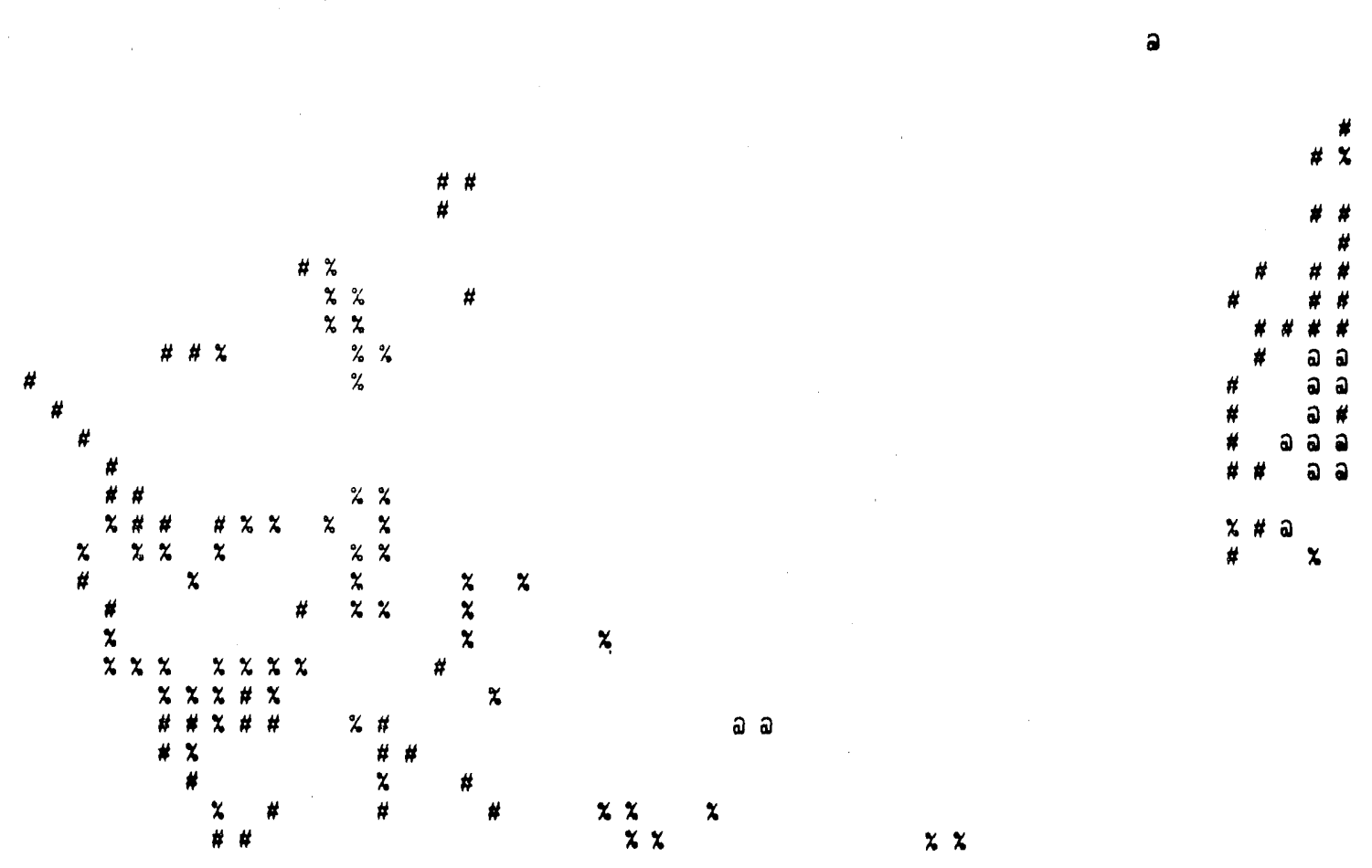

91111119119191191111111911222222222222222222222222233 .00011222334445566677888990001122223344455666778889900

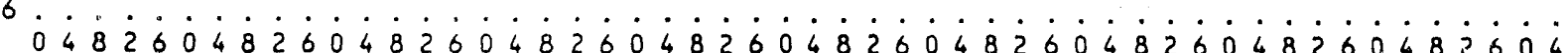
LONG 
Fig. A-6. Locations where Forest (as per AVHRR) is indicated as Savanna (by FAO) symbolized as '\#', and where Savanna (as per AVHRR) is indicated as Forest (by FAO) symbolized as '\&'.

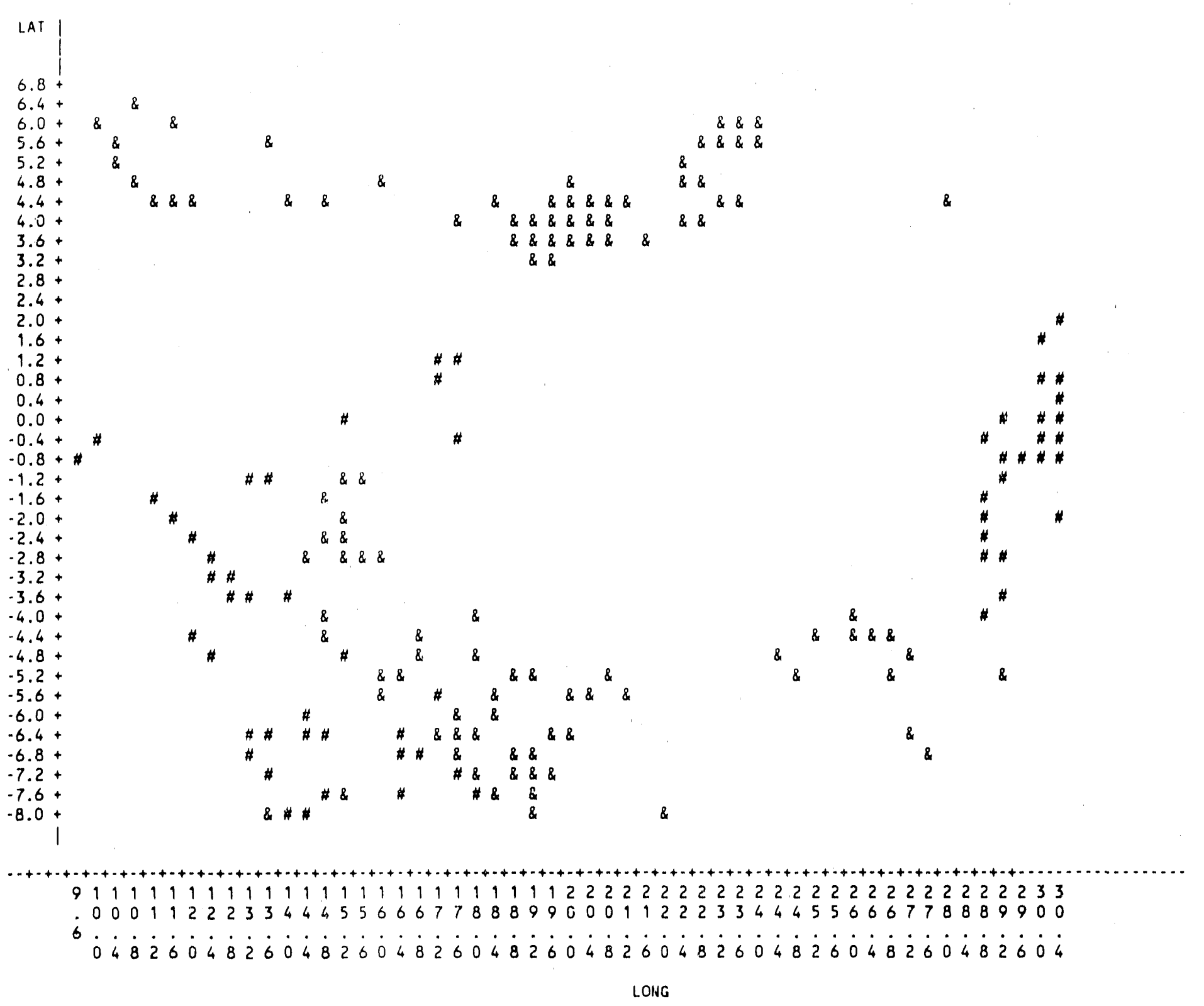


Fig. A-7. Plot Showing Locations of Agreement and Disagreement between the AVHRR and FAO maps. 'F' symbolizes Agreement with regard to Forests

'S' symbolizes Agreement with regard to Savanna

' $M$ ' symbolizes Agreement with regard to Mixed Forest/Savanna.

'@' symbolizes Locations where Forest (as per AVHRR) is Indicated as Mixed Forest/Savanna (by FAO)

'\#' symbolizes Locations where Forest (as per AVHRR) is Indicated as Savanna (by FAO)

'\$' symbolizes Locations where Mixed Forest/Savanna (as per AVHRR) is Indicated as Forest (by FAO)

'\%' symbolizes Locations where Mixed Forest/Savanna (as per AVHRR) is Indicated as Savanna (by FAO)

' $\&$ ' symbolizes Locations where Savanna (as per AVHRR) is indicated as Forest (by FAO)

'*' symbolizes Locations where Savanna (as per AVHRR) is Indicated as Mixed Forest/Savanna (by FAO)

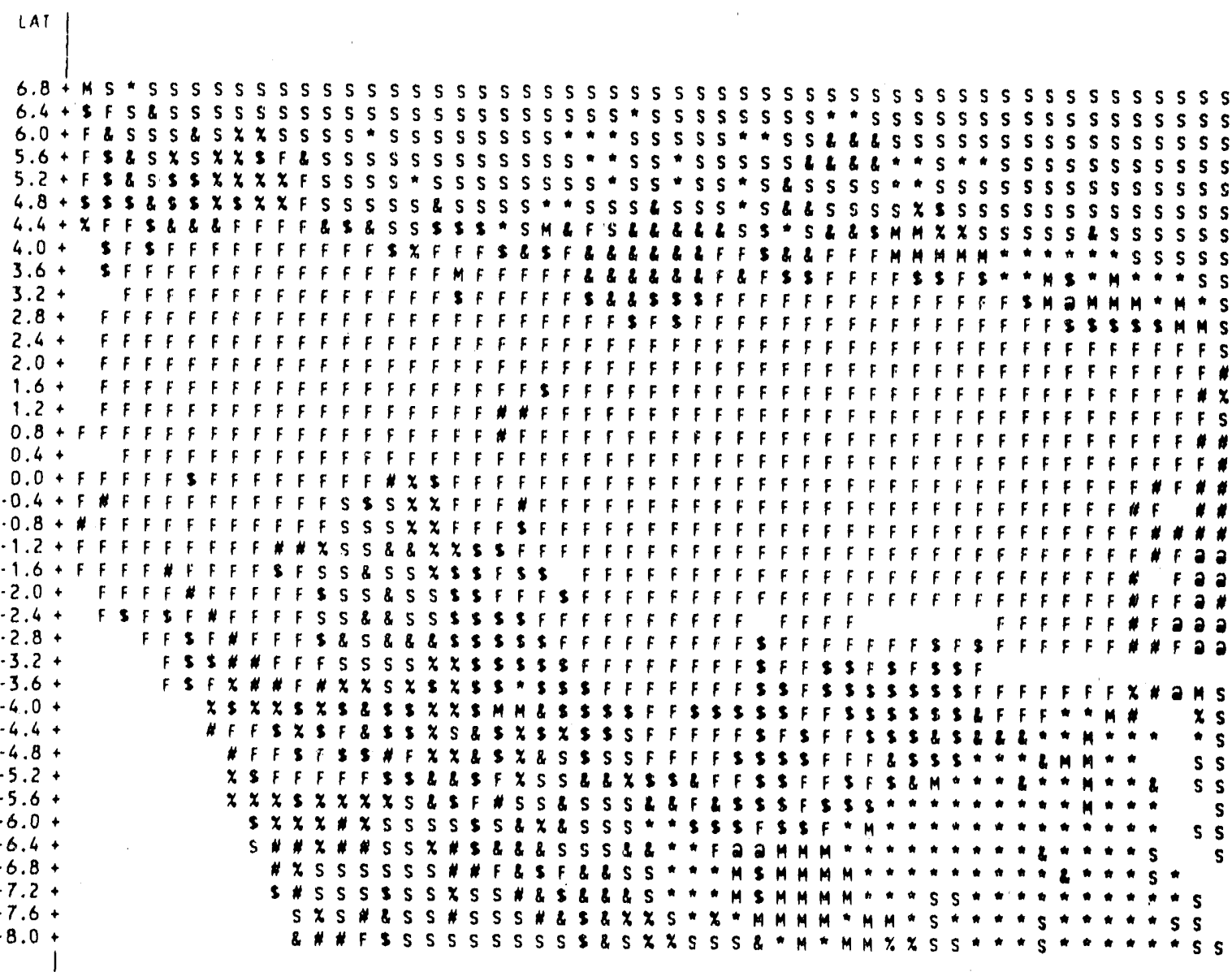

9111111911111911911111111111222222222222222222222222233

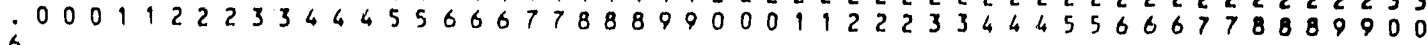

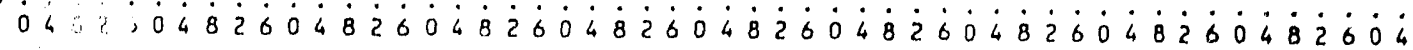




\section{REFERENCES}

A.I.D. (U.S. Agency for International Development), "New Directions for A.I.D. Renewable Energy Activities", Office of Energy, U.S. Agency for International Development, report \# 88-01, Washington, D.C., February, 1988.

Allen, J.C., "Soil response to forest clearing in the United States and the tropics: geological and biological lactors, Biotropica 17:15-27, 1985.

Anderson, D. and R. Fishwick, Fuelwood Consumption and Deforestation in African Countries, World Bank, Washington, 1984.

Anderson, D., The Economics of Afforestation - A Case Study in Africa, The World Bank Occasional Paper Number 1/New Series, The Johns Hopkins University Press, Baltimore, 1987.

Armitage, J. and G. Schramm, "Managing the Supply and Demand for Fuelwood in Alrica," In Environmental Management and Economic Development, edited by G. Schramm and J. J. Warford, Johns Hopkins University Press, Baltımore, 1989.

Brown, S., Letters, Science, 241:1739, 1988.

Brown, S. and A. E. Lugo, "Biomass of Tropical Forests: A New Estimate based on forest volumes'," Science, 223:1290-1293, 1984.

Cicerone, R.J., "Analysis of sources and sinks of atmospheric nitrous oxide $\left(\mathrm{N}_{2} \mathrm{O}\right)$, , J. Geophysicial Research, 94:18265-18721, 1989.

Dale, V.H. (editor), "Report of a workshop on using remote sensing to estimate land-use change," Summary of panel discussions at a conference held at the National Zoo, Washington, D.C., U.S. DOE, Oak Ridge National Laboratory, Oak Ridge, TN, 1989.

Darmstadter, J., and J. Edmonds, "Human Development and $\mathrm{CO}_{2}$ Emissions: Current Picture and Long-Term Prospects," in N.J. Rosenberg et al. (eds.), Greenhouse Warming: Abatement and Adaptation, 1988.

de Montalembert, M. 'R. and J. Clement, Fuelwood Supplies in the Developing Countries, Food and Agriculture Organization, Rome, 1983.

Detwiler, R.P., and C.A.S. Hall,"Tropical Forests and the Global Carbon Cycle," Science, 239:42-47, 1988.

Elkan, W., "Alternatives to Fuelwood in African Towns," World Development, Vol. 16:527533, 1988. 
Emanual, W.R., G.G. Killough, W.M. Post, and H.H. Shugart, "Modeling Terrestrial Global Carbon Cycle with Shifts in Carbon Storage Capacity by Land-Use Change," Ecology, 65:970983, 1984.

EPA (U.S. Environmental Protection Agency), Policy Options for Stabilizing Global Climate, Draft, Vol 1: Chapter I-IV, U.S. EPA, Office of Policy, Planning, and Evaluation.

Washington, D.C., 1989.

ESRI (Environmental Systems Research Institute), Final Report UNEP/FAO World and Africa GIS Database, ESRI, 380 New York St., Redlands, CA., 1984.

Ewing, A. J. and R. Chalk, The Forest Industries Sector: An Operational Strategy for Developing Countries, World Bank Technical Paper 83, Industry and Energy Series, World Bank, Washington, 1988.

Flavin C. 1989, Slowing Global Warming: A Worldwide Strategy, Climate Institute, Washington D.C., 1989.

Food and Agriculture Organization (FAO), Agriculture: Toward 20(0), Rome, 1981.

FAO (Food and Agriculture Organization), Potential Population Supporting Capacities of Lands in the Developing World, Technical Report FPA/INT/513, Rome, 1982.

FAO (Food and Agriculture Organization), FAO Maps and Statistical Data on Population and Crops by Administrative Units, FAO, Rome, 1983.

FAO (Food and Agriculture Organization), FAO Map of Mcan Annual Rainfall and Gencral Climate Zones for P/PET for Africa, Prepared by Todor Boyadgiev, Soil Resources Management and Conservation Service, FAO, Rome, 1983.

FAO (Food and Agriculture Organization), Changes in Shifting Cultivation in Africa, Forestry Paper 50, Rome, 1984a.

FAO (Food and Agriculture Organization), Land, Food and People, Rome, 1984b.

FAO (Food and Agriculture Organization), Institutional Aspects of Shifting Cultivation in Africa, Rome, 1984c.

FAO (Food and Agriculture Organization), The Tropical Forestry Action Plan, Prepared by FAO in cooperation with the World Bank, United Nations Development Program, and the World Resources Institute, Ronie, 1987.

FAO/UNEP (Food and Agriculture Organization / United Nations Environment Program), Forest Resources of Tropical Africa, Tropical Forest Resources Assessment Project, Vol. 1 \& 2, Rome, 1981.

FAO/UNESCO (Food and Agriculture Organization / United Nations Educational, Scientific, and Cultural Organization), Soil Map of the World, Vol. VI. Africa, 1977. 
French, D., "Conlronting an Unsolvable Problem: Deforestation in Malawi," World Development, 14:531-540, 1985.

Harmon, M. E., W. K. Ferrell, and J. F. Franklin, "Effects on Carbon Storage of Conversion of Old-Growth Forests to Young Forests," Science, 247:699-7(03, 1990).

Houghton, R.A., R.D. Boone, J.M. Melillo, C.A. Palm, G.M. Woodwell, N. Myers, B. Moore III, and D.L. Skole. 1985a, "Net Flux of Carbon dioxide from Tropical Forests in 1980,"

Nature, 316:617-620, 1985a.

Houghton, R.A., R.D. Boone, J.R. Fruci, J.E. Hobbie, J.M. Melillo, G.A. Palm, B.J. Peterson, G.R. Shaver, and G.M. Woodwell, "The Flux of Carbon from Terrestrial Ecosystems to the Atmosphere in 1980 Due to Changes in Land use: Geographic Distribution of the Global Flux," Tellus 39B:122-139, 1987.

Houghton, R.A., J.E. Hobbie, J.M. Mclillo, B. Moore, B.J. Peterson, G.R. Shaver, and G.M. Woodwell, "Changes in the Carbon Content of Terrestrial Biota and Soils between 1860) and 1980: A Net Relcase of $\mathrm{CO}_{2}$ to the Atmosphere", Ecological Monographs, 53(3):235-262, 1983.

Houghton, R.A., W.H. Schlesinger, S. Brown, and J.F. Richards, "Carbon dioxide Exchange Between the Atmosphere and Terrestrial Ecosystems," in Atmospheric Carbon Dioxide and the Global Carbon Cycle, Edited by, J.R. Trabalka, Oak Ridge National Laborator;

Tennessee, 1985b.

Iverson, L.R., E.A. Cook, and R.L. 'Jraham, "A technique for extrapolating and validating forest cover across large regions calibrating AVHRR data with TM data," Int. J. Remote Scnsing, 10(11):1805-1812, 1989.

Jones, H. M., "Energy Efficient Stoves in East Africa: An Assessment of the Kenya Ceramic Jiko Program", Office of Energy, Agency for International Development, report \# 89-(01, Washington, D.C., January, 1989.

Kalapula, E. Shamilupa. 1989, "Woodfucl Situation and Deforestation in Zambia," Ambio, 18(5):293-294, 1989.

Killough, G.G. and W.R. Emanual, "A comparison of several models of carbon turnover in the ocean with respect to their distributions of transit time and age and response to atmospheric $\mathrm{CO}_{2}$ and ${ }^{14} \mathrm{C}$," Tellus, 33:274-290, 1981.

Lal, R., "Potential of Agroforestry as a Sustainable Alternative to Shifting Cultivation: Concluding Remarks," Agroforestry Systems, 8:239-242, 1989.

Lanly, J.P., Tropical Forest Resources, FAO Forestry Paper 30, Rome, 1982.

Lavenu, F., Digitized Vegetation Map of Africa - Descriptive Memoir and Map Prepared for the Department of Forestry Resources, FAO, Rome, 1987. 
Leach, G. and M. Gowen, Household Energy Handbook: An Interim Guide and Reference Manual, World Bank T'echnical Paper No. 67, World Bank, Washington, 1987.

Leach, G. and R. Mearns, Beyond the Woodfuel Crisis: People, Land and Trees in Africa, Earthscan Pulications, London, 1988.

Leslie, A. J., "A Second Look at the Economics of Natural Management Systems in Tropical Mixed Systems," Unasylva, 39:46-58, 1987.

Lieth, H., "Modeling the primary productivity of the world," H. Lieth and R.H. Whittaker, eds. Primary productivity of the Blosphere, pp 237-263. Spring Verlag, New York, 1975.

Lintu, L., "Paper and Paperboard in Developing Countries: The Potential Is There," Unasylva, 36(144):23-28, 1984.

Lugo, A.E., S. Brown, and J. Chapman, "An analytical review of production rates and stemwood biomass of tropical forest plantations," For. Ecol. Manage., 23:179-200, 1988.

Maitre, H. F., "Natural Forest Mangement in Cote d'Ivoire," Unasylva, 39(3\&4):53-60), 1987.

Malingreau, J., and C. J. Tucker. 1988, "Large-scale deforestation in the southeastern Amazon basin of Brazil," Ambio, 17: 49-55, 1988.

Marland, G., T.A. Boden, R.C. Griflin, S.F. Huang, P. Kanciruk, and T.R. Nelson, Estimates of $\mathrm{CO}_{2}$ emissions from fossil fucl burning and ecment manufacturing, Based on the United Nations Energy Statistics and the U.S. Bureau of Mines, ORNL/CDIAC-25, Oak Ridge National Laboratory, Oak Ridge, l'ennessec, 1989.

Millington, A, J. Townsend. P. Kennedy, R. Saull, S. Prince and R. Madams, Biomass Assessment - Woody Biomass in the SADCC Region, Earthscan Publications Lid. London, 1989.

Myers, N., Conversion of Tropical Moist Forests, National Research Council, National Academy of Sciences, Washington D.C., 1980.

Myers, N., The Primary Source: Tropical Forests and Our Future, W.W. Norton \& Co., New York, 1984.

Nelson, R. and B. Holben, "Identifying deforestation in Brazil using multiresolution satellite data," Int. J. Remote. Sensing, 7:429-448, 1986.

Nelson, R., N. Họning, and T.A. Stone, "Determining the rate of forest conversion in Mato Grasso, Brazil, using Landsat MSS and AVHRR data," Int. J. Remote Sensing, 12(8): 17671784, 1987a.

Nelson, R., D. Case, N. Horning, V. Anderson, and S. Pillai, "Continental land cover assessment using Landsat MSS Data," Remote Sensing of Environment, 21: 61-81, $1987 \mathrm{~b}$. 
Office of Technology Assessment (OTA), Africa Tomorrow: Issues in Technology, Agriculture, and U.S. Foreign Aid, Congress oi the United States, Waslington, December, 1984.

Okigbo, B. N., Improved Permanent Production Systems as an Alternative to Shifting Cultivation, Food and Agriculture Organization, FAO Soils Bulletin 53, Rome, 1984.

Olson, S. J., J. A. Watts, and L. J. Allison, Major World Ecosystem Complexes Ranked by Carbon in Live Vegetation: A Data base, Oak Ridge National Laboratory, Tennessec, 1985.

Raintree, J. B., Agrofosestry, Tropical Land Use and Tenure, International Council for Research in Agroforestry (ICRAF), Background Paper for the International Consultative Workshop on Tenure Issues in Agroforestry, Nairobi, May 1985.

Raintrec, J. B., "Agroforestry Pathways: Land Tenure, Shifting Cultivation and Sustainable Agriculture," Unasylva, 38(154), 1986.

Ramanathan, V., R.J. Cicerone, H.B. Singh, and J.T. Kichl, "Trace gas trends and their potential roles in climate change," J. Geophysical Research, 9):5547-5566, 1985.

Rand-McNally, The New Internationa! Atlas, Chicago, 1982.

Repetto, R. and M. Gillis, Public Policies and the Misuse of Forest Resources, Cambridge University Press, Cambridge, 1988.

Rosenberg, N.J., W.E. Easterling III, P.R./ Crossen, and ¿. Darmstadter (eds), Greenhouse Warming: Abatement and Adaption. Resources For The Future, Washington, D.C., 1989.

Ruthenberg, H., Farming Systems in the Tropics, Third edition, Clarendon Press, Oxford, 1980 .

Schneider, H. S., "The Changing Climate", Scientifïc Amcrican, 261(3), 1989.

Singh, K.D., "The conceptual framework of the FAO - Forest Resources Assessment 1999)," Proceedings of the International Conference and Workshop: Global Natural Resource Monitoring and Assessments: Preparing for the 21st eentury. Venice, Italy Sept. 24-30, 1989, American Socicty of Photogrammetric Enginecring and Remote sensing, In Press.

Solomon, A.M. J.R. Trabalka, D.E. Reichle, and L.D. Voorhees, "The Global Cycle of Carbon," in J.R. Trabalka (ed.) Atmospheric Carbon Dioxide and the Global Carbon Cycle, U.S. Department of Eneray. 1985.

Torres, F., "Potential Contribution of Leucaena Hedgerows Intercropped with Maize to the Production of Organic $N$ and Fuclwood in the Lowland Humid Tropics," Agroforestry Systems, 1:323-3.33, 1983.

UNDP/ESMAP, "Niger Improved Stoves Project", December Activity Completion Paper \# 080/87, World Bank, Washington, D.C., 1987. 
United Nations Energy Statistics Data Tape, Department of International Economic and Social Affairs, United Nations, New York, New York, 1987.

United Nations, 1987 Energy Statistics Yearbook, United Nations, New York, New York, 1989.

U. S. Department of Energy (DOE), Energy and Climate Change: Report of the DOE MultiLaboratory Clinuate Change Committec. Lewis Publishers, Chelsea, Michigan, 1990.

Walter, H., Vegetation of the Earth, Springer Verlag, New York, 1973.

White, F., The Vegetation of Africa with Accompanying Maps, Unesco, 1983.

Wilkinson, G. K., The Role of Legislation in Land-use Planning for Developing Countries, Food and Agriculture Organization, Legislative Study No. 31, Rome, 1985.

Woodward, F.I., Climate and plant distribution, Cambridge University Press, New York, 1987.

World Bank, A Survey of the Future Role of Hydroelectric Power in 100 Developing

Contries, Washington, 1984.

WRI/IIED (World Resources Institute/The International Institute for Environment and Development), Tropical Forests: A Call for Action, World Resources Institute, Washington, 1985.

WRI/IIED (World Resoures Institute/The International Institute for Environment and Development), World Resources 1986, Basic Books, New York, 1986.

WRI/IIED (World Resources Institute/The International Institute for Environment and Development), World Resources 1988-89, Basic Books, New York, 1988. 

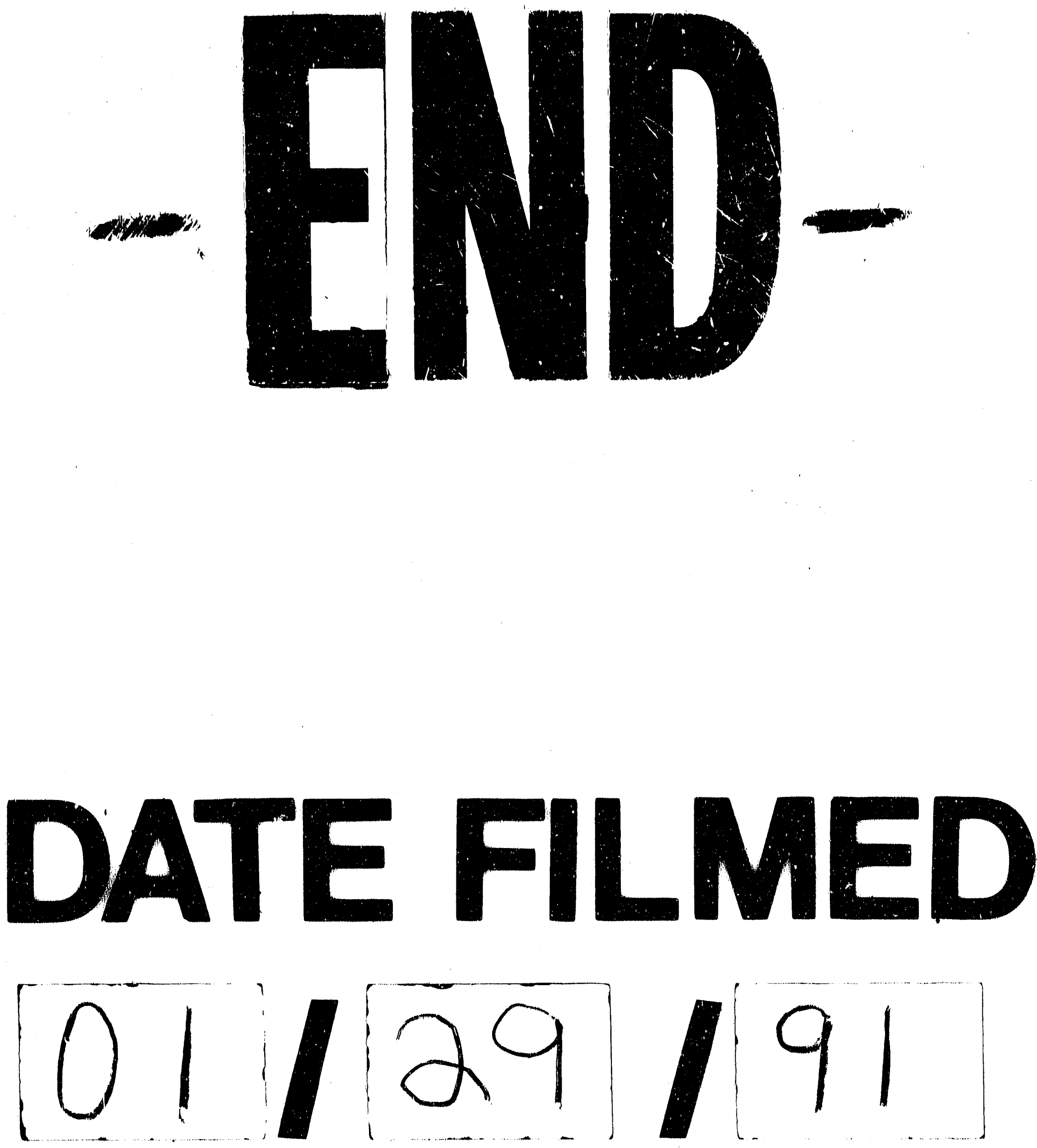